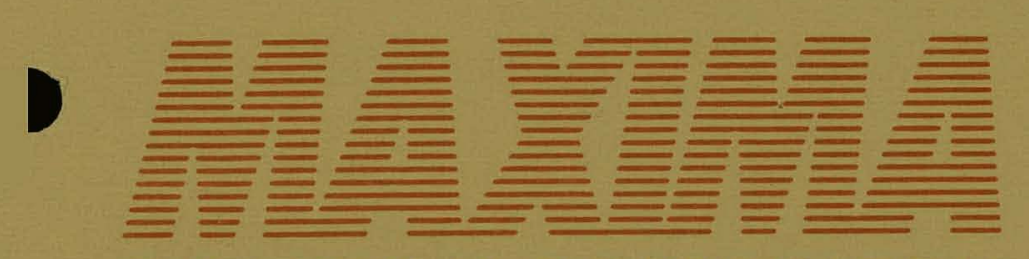

THE MAXIMA CORPORATION

\title{
REVIEW OF A \\ PROPOSED QUARTERLY COAL PUBLICATION
}

\author{
Prepared by \\ The MAXIMA Corporation \\ January 1981
}

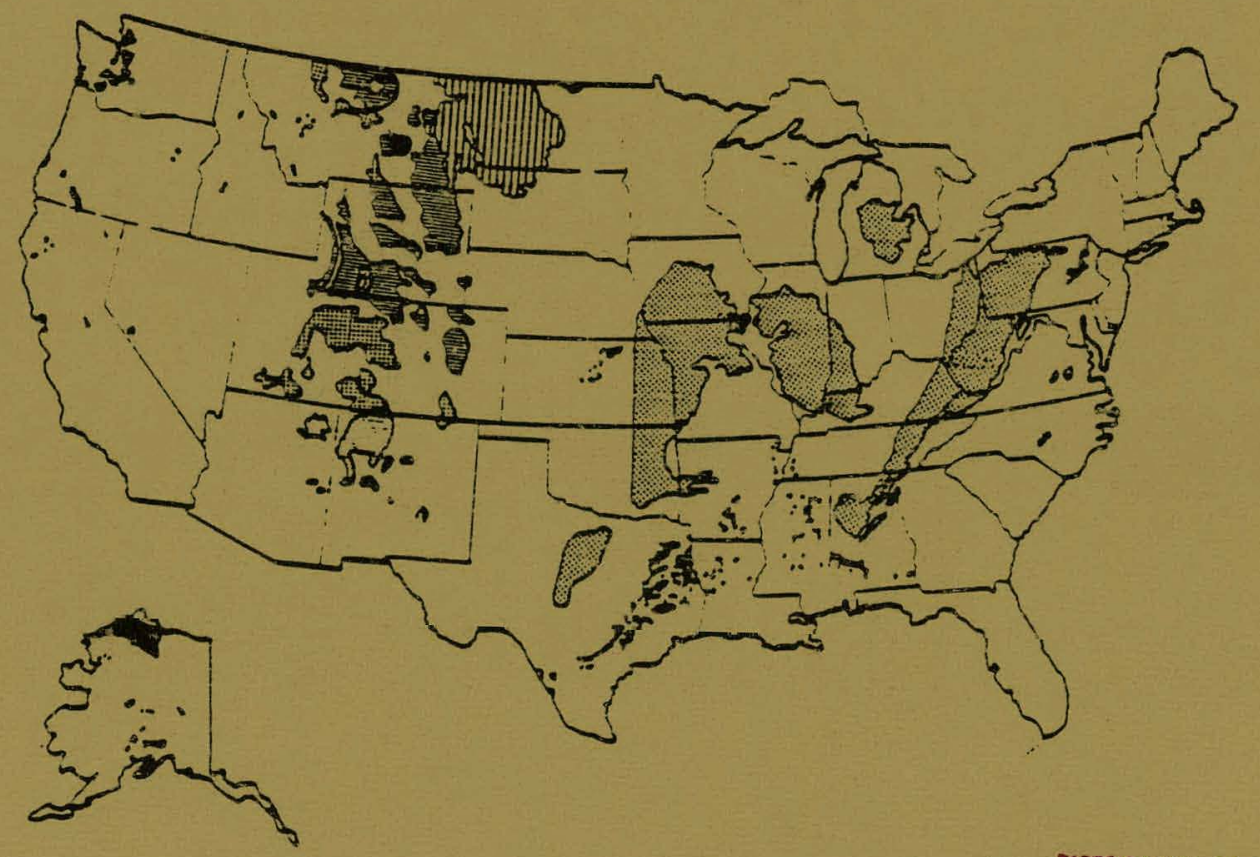




\section{DISCLAIMER}

This report was prepared as an account of work sponsored by an agency of the United States Government. Neither the United States Government nor any agency Thereof, nor any of their employees, makes any warranty, express or implied, or assumes any legal liability or responsibility for the accuracy, completeness, or usefulness of any information, apparatus, product, or process disclosed, or represents that its use would not infringe privately owned rights. Reference herein to any specific commercial product, process, or service by trade name, trademark, manufacturer, or otherwise does not necessarily constitute or imply its endorsement, recommendation, or favoring by the United States Government or any agency thereof. The views and opinions of authors expressed herein do not necessarily state or reflect those of the United States Government or any agency thereof. 


\section{DISCLAIMER}

Portions of this document may be illegible in electronic image products. Images are produced from the best available original document. 


\section{REVIEW OF A \\ PROPOSED QUARTERLY COAL PUBLICATION}

Submitted to

The Office of Energy. Data Operations (OEDO)

Energy Information Administration (EIA)

Under Contract No. DE-ACOI-80EI-10313

\section{Prepared by \\ The MAXIMA Corporation \\ 7315 Wisconsin Avenue \\ Suite 900N}

Bethesda, Maryland 20014

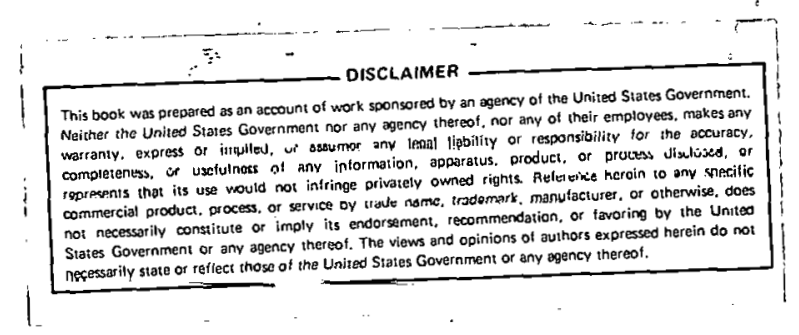




\section{Table of Contents}

Page No.

Executive Sumary. . . . . . . . . . . . . . . . . iii

Introduction . . . . . . . . . . . . . . . . . . : v

Selected User Surveys. . . . . . . . . . . . . . . . 1

Major Functions of the Coal and Coke Industries. . . . . . . . 9

Analysis of Coal and Coke Data Collection Activities . . . . . . . 11

Analysis of the Proposed Quarterly Coal Review . . . . . . . 19

Comparison of the Proposed QCR w1th Other EIA Publications . . . . 49

Appendices
A. Abstracts of Coal and Coke Reporting Forms . . . . . . 57
B. Coal and Coke Data Reporting Forms............ 63
C. Related Publications and Data Sources. . . . . . . . . 97
D. Geographic Aggregations Used in Selected EIA Publications. 99 
THIS PAGE

\section{WAS INTENTIONALLY LEFT BLANK}




\section{Executive Summary}

This "Review of a Proposed Quarterly Coal Publication" contains findings and recommendations regarding the content of a new sumary Energy Information Administration (EIA) coal and coke publication entitled The Quarterly Coal Review (QCR). It is divided into five sections: results of interviews with selected EIA data users; identification of major functions of the coal and coke industries; analysis of coal and coke data collection activities; evaluation of issues concerning data presentation including recommendations for the content of the proposed $Q C R$; and comparison of the proposed QCR with other EIA publications. The report addresses substantive issues concerning the QCR within each of the five sections. Our major findings and recommendations are as follows:

- User interviews indicate a definite need for a comprehensive publication that would support analyses and examine economic, supply and demand trends in the coal industry.

- The organization of the publication should reflect the natural order of activities of the coal and coke industries. Based on an analyais of the induetrico, these functious are:

- Production

- Stocks

- Imports

- Exports

- Distribution

- Consumption

- Current EIA coal and coke surveys collect sufficient data to provide a summary of the coal and coke industries on a quarterly basis. 
- Coal and coke data should be presented separately. Coke data could be presented as an appendix.

- Three geographic aggregations are recommended in the QCR. These are:

- U.S. Total

- Coal Producing District

- State

- Loal consumption data should be consolidated into four major consumer categories:

- Electric Utilities

- Coke Plancs

- Other Industrial

- Residential Commercial

- Several EIA publications could be eliminated by the proposed $Q C R$. These include the Coal Distribution Quarterly, Bituminous Coal and Lignite Production and Mine Operations, and the Coke and Coal Chemicals Monthly. Two other EIA publications, the Coke and Coal Chemicals Annual and Bituminous Coal and Lignite: Production and Mine Operations could be integrated into the QCR as annual supplements.

These findings and recommendations are the results of our analysis of the issues cuncerning the publlcacton of lhe QCR. In the renalning sections, we will expand on the rationale behind each finding and recommendation. 


\section{Introduction}

The purpose of this "Review of a Proposed Quarterly Coal Publication" is to make recommendations on the content of a new summary coal and coke publication entitled the Quarterly Coal Review (QCR). The recommendations are based on our analysis of selected user interviews, the functions or activities of the coal and coke industries, active coal and coke data collection activities, and current Energy Information Administration (EIA) publications which present coal and coke data.

This report is divided into five sections:

- Selected User Interviews

- Major Functions of the Coal and Coke Industries

- Analysis of Coal and Coke Data Collection Activities

- Analysis of the Proposed Quarterly Coal Review

- Comparison of Proposed QCR with Other EIA Publications.

Selected User Interviews, the first section of this report, describes the results of a telephone survey conducted of a sampling of subscribers to EIA : coal and coke publications. The survey was implemented to determine the general needs of users of EIA coal and coke publications. The next section, Major Functions of the Coal and Coke Industries, analyzes the key functions required to reflect the flow of coal and coke from the mine to the consumer. These requirements are then compared with current DOE/EIA data collection activities in the third section of the report. This comparison identifies what data are reported and analyzes where information gaps currently exist. Based on the availability of data, an analysis of the issues concerning the content of the $Q C_{R}$ is included in the fourth section. Data presentation, organization, and beginning and ending materials are discussed and possible tables and graphs for the proposed QCR are also listed in this section. The last section of the report compares the proposed QCR with existing EIA publications. 


\section{Selected User Interviews}

The initial step in reviewing a proposed quarterly coal publication is to understand the needs of the readership. To help determine the general needs of coal data users and to gain a perspective on how coal data publications are used within government and the private sectors, a telephone survey of selected users was initiated. This survey was by no means exhaustive of coal data users or user needs, but rather served as a vehicle to obtain a general understanding of users'needs for published coal data. Based on the preliminary results from a user requirements survey for coal production data compiled by MAXIMA under subcontract to Oak Ridge National Laboratory, and telephone conversations with representatives from the Office of Coal and Electric Power Statistics (OCEPS), names of coal data users (See Table 1) and guidelines for conducting user interviews were obtained.

\section{Methodology}

Three OCEPS representatives were contacted (Noel Balthaser, Leonard Westerstrom, and Robert Harris) to obtain the following information:

- Who in the private sector uses Energy Information Administration (Eì) Coal and Cókè publicátions?

- What kind of published data do users require on a regular basis?

- Of the data currently published, which data are considered significant or insignificant?

Based on recommendations from these three OCEPS representatives, we obtained a user mailing list of names of coal data users in the government and private sectors from EIA's Office of Energy Information Services. We also contacted the National Coal Association's library to obtain a listing of their coal publications. Names and telephone numbers of individuals contacted for the interviews are listed on Table 1. 
Table 1. Individuals Contacted During User Interviews

\begin{tabular}{|c|c|}
\hline Name & Phone Number \\
\hline $\begin{array}{l}\text { Penn State University } \\
\text { James Hartigan, Economist }\end{array}$ & $(814) 865-4700$ \\
\hline $\begin{array}{l}\text { EIA Clearinghouse } \\
\text { Richard Frances }\end{array}$ & $252-1185$ \\
\hline $\begin{array}{l}\text { National Coal Association } \\
\text { Library }\end{array}$ & $463-2625$ \\
\hline $\begin{array}{l}\text { DOI } \\
\text { Office of Coal Management } \\
\text { Ryan Dubley, Economist }\end{array}$ & $343-4537$ \\
\hline $\begin{array}{l}\text { nnI } \\
\text { Office of Policy Analysis } \\
\text { Charlie Towle }\end{array}$ & $343 \cdot 2131$ \\
\hline $\begin{array}{l}\text { DoI } \\
\text { Office of Coal Leasing Planning Coordination } \\
\text { Mr. Pat Geehan } \\
\text { Deputy Director }\end{array}$ & $343-4191$ \\
\hline $\begin{array}{l}\text { Penn State University } \\
\text { Matt Ott, Economist }\end{array}$ & $(814) 865-1533$ \\
\hline $\begin{array}{l}\text { Penn State University } \\
\text { Nineral Economics Department }\end{array}$ & $(814) \quad 253-8306$ \\
\hline
\end{tabular}


Table I. continued

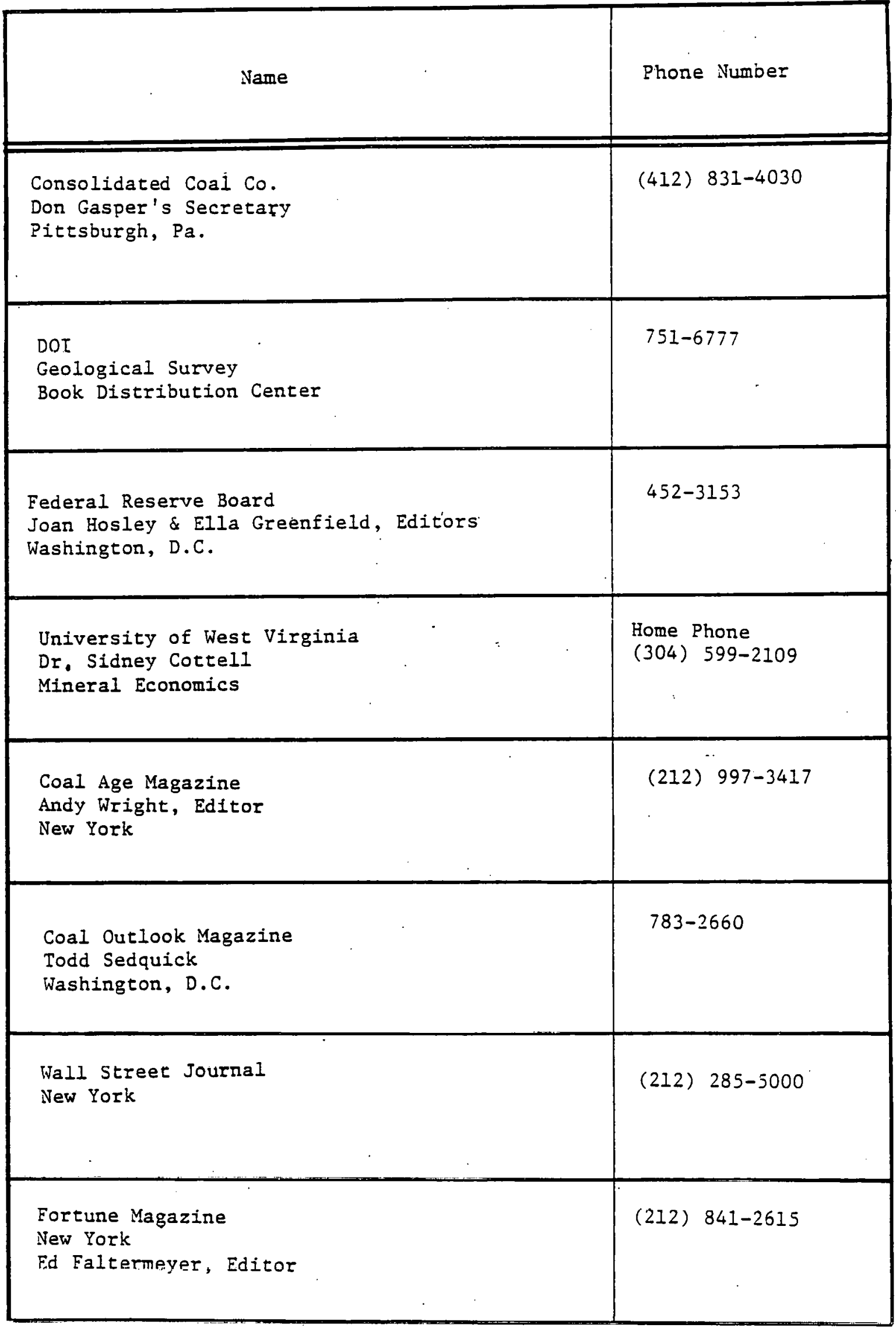


Table 1. continued

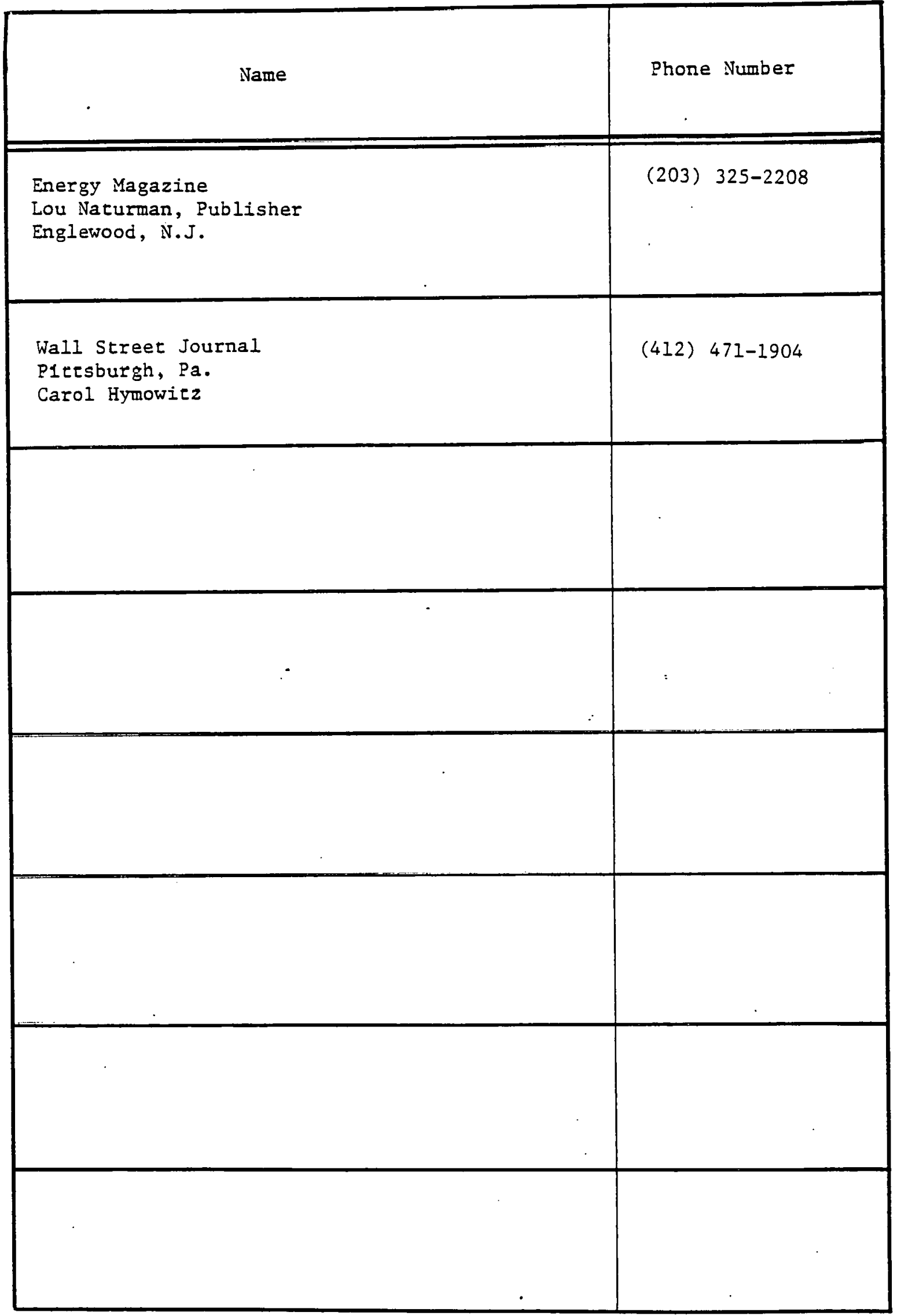


The following questions were asked during each interview:

- Which publications do you use?

- Who publishes them?

- What data do you require?

Results of this survey are organized by type of respondent (government, private industry, higher education) in the paragraphs below.

\section{Interviews with Government}

Based on recommendations from OCEPS officials, representatives from the following government offices were interviewed:

- Federal Reserve Board

- Bureau of Labor Statistics

- Department of Interior.

The Federal Reserve Board (FRB) publications office is interested exclusively in coal production data. They produce a monthly publication entitled The U.S. Industrial Production Index that depicts output, utility and mining data. The FRB requires timely and accurate coal data for prompt estimates of coal production. Currently they use EIA's Weekly Coal Production Report as their primary source for constructing statistical tables for this publication.

The Bureau of Labor Statistics (BLS) is concerned with employment estimates. Although moot of the nccesary coal data are collected within BL3, EIA publications (primarily the Weekly Coal Production Report) are also used as input to statistical indices. The National Coal Association (NCA) publications provide BLS with another source of coal data. In addition, trade periodicals are used for data analysis; for example, Coal Age and Coal Outlook. 
Representatives were contacted from various offices within the Department of Interior (DOI). The results of these interviews include:

- The purpose of the Office of Coal Management (DOI) is to lease federal areas for coal production and prepare environmental impact statements and analysis reports for leasing surface mining tracts. They use the Weekly Coal Production Report to supplement their own research activities.

- The Office of Coal Leasing Planning Coordination (DOI) is concerned primarily with legal and policy decisions. Most of their data are collected from the Bureau of Land Management (DOI). However, EIA statistics are used when a specific technical decision has policy implications. The EIA publications most frequently used are:

- Monthly Energy Review

- Bituminous and Subbituminous Coal and Lignite Distribution, and

- Annual Report to Congress.

Trade magazines and data from the various state mining offices are also used in the analysis of coal production.

\section{Interviews with Private Industry}

Representatives from the following companies and journals were intervlewed to determine their coal data requirements:

- Consolidated Coal Compàny

- amaX Coal Company

- Coal Age

- Coal Outlook

- Energy Magazine

- Fortune Magazine

- Wall Street Journal.

Results from these interviews indicate the widespread use of coal and coke dața that are currently collected and published by EIA and other federal 
agencies. Several representatives suggested the need for one publication that was comprehensive in scope and published on a regular cycle. Currently, export figures are published in the Weekly Coal Production Report, whereas consumption data are published in the Monthly Energy Review and distribution data are published quarterly in Coal Distribution. The representatives indicated that they would like to see this information consolidated and published within the same time interval.

Another expressed need was for comparable data elements. Production data are aggregated by mining district, whereas consumption data are aggregated by state. These different aggregations and data types make comparisons difficult. Moreover, data comparability is further hampered by the varying formats used in the existing coal and coke publications.

Representatives also expressed the desire for weekly and/or monthly data rather than quarterly data and for data that facilitate plotting of coal industry trends.

\section{Interviews with Higher Education}

Three universities located in major coal producing states were contacted to obtain input from the academic environment.

The University of West Virginia, Mineral Economics Department, is concerned primarily with energy economics (i.e., supply and demand). They receive EIA and National Coal Association (NCA) publications - the most important of which is EIA's Weekly Coal Production Report. Trade magazines contain very limited data for their needs. This user would benefit if coal supply data could be aggregated by county and state.

The University of Kentucky, College of Engineering Department, is interested in legislative issues, mining practices, employment and economics. These users review EIA and NCA publications but use trade publications and journals as primary sources for their needs. 
Users interviewed from the Pennsylvania State University, Mineral Economics Department, indicated a primary interest in consumption, production, pricing, and transportation data. The EIA publications most frequently used are:

- The Weekly Coal Production Report

- The EIA Annual Report to Congress

- Bituminous and Subbituminous and Lignite Distribution

Other sources currently used are NCA publications and the Keystone Coal Industry Manual (used for production and consumption data). Rilarterly informatiun is nor useful for this instituiton. Weekly reporting is most useful and t1meliness and accuracy are the major considerations for these users. This institution would benefit if districts encompassing large territories could be divided into sub-districts.

\section{Summary}

Our user interviews indicated a definite desire for a timely, comprehensive coal publication that would support analyses and examine trends un production, consumption, transportation, mining practices, and coal economics with comparable data elements and data categories. Aggregations by state would also be desirable. 


\title{
Major Functions of the Coal and Coke Industries
}

\author{
$\dot{A}$ summary coal and coke publication should present data describing \\ major functions or activities of the respective industries. Ordering the \\ publication so that it represents the flow of coal and coke from extraction \\ (processing in the case of coke) through consumption provides a logical \\ framework for the reader to follow. \\ A common way of defining this flow is through the derivation of input- \\ output equations that attempt to reconcile or "balance" supply and demand. \\ One equation that represents the flow of coal and coke is as follows:

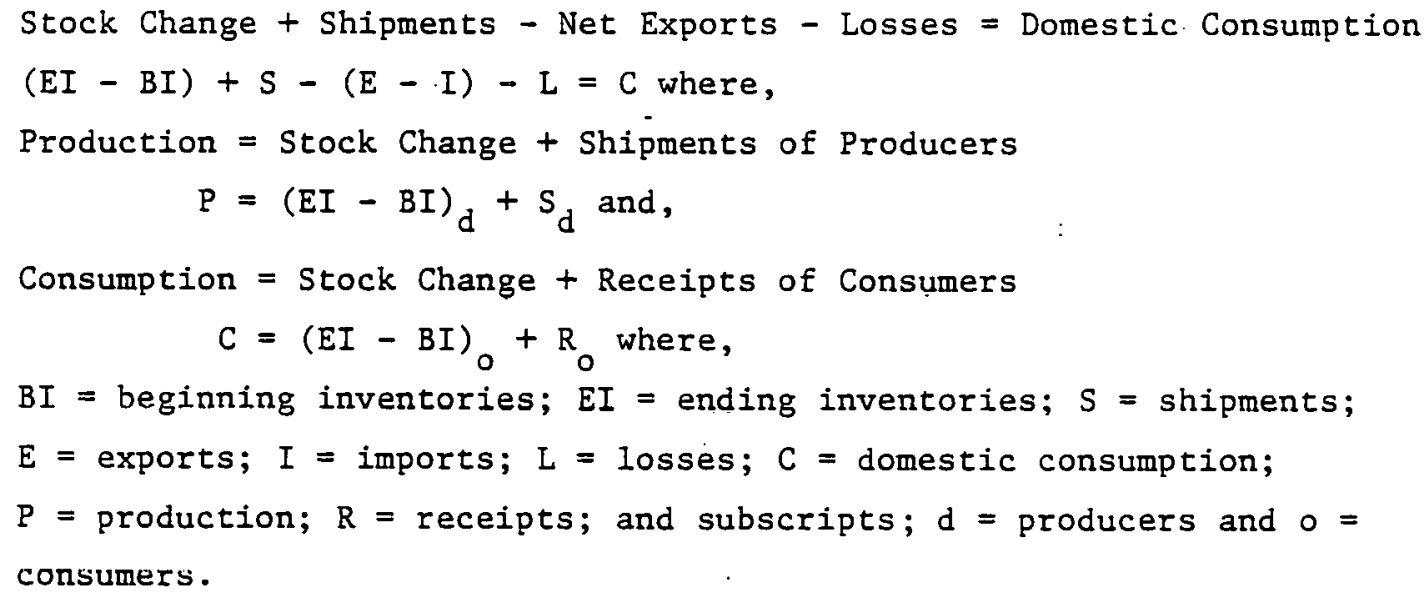

There are, however, major functions represented in the previously derived equation that should be described in a summary coal publication. These functions may also serve as an organizational framework for the proposed Quarterly Coal Review (QCR). 
These functions include:

- Production (includes shipments and stock change of producers)

- Stocks (includes stock change of distributors)

- Distribution (includes transportation method and destination)

- Net Exports (includes exports minus imports)

- Consumption (includes receipts and stock change of consumers).

The above functions represent an equation which computes the domestic cunsumption of coal and coke. These functions can be rearranged to reflect supply and demand:

$\begin{array}{ll}\text { Supply } & \text { Demand } \\ \text { Production } & \text { Exports } \\ \text { Stocks } & \text { Distribution } \\ \text { Imports } & \text { Consumption }\end{array}$

Before recommendations can be made for the inclusion of each of the major functions presented in either format in the QCR, it is necessary to compare these functions with the data currently collected and published to assess the necessity and feasibility of implementing such an organizational structure. 


\section{Analysis of Coal and Coke Data Collection Activities}

This section of the report contains an analysis of coal and coke data collection activities. The results of this analysis will indicate whether comprehensive industry data are currently collected and, if so, their applicability for use in a summary periodical. Although a variety of coke and coal data are collected and published by various organizations, this analysis was limited to federal agency sources which collect data on an annual or more frequent basis and which are readily accessible to EIA.

For ease of ${ }^{\circ}$ comparison, the data sources are presented in Table 2, Availability of Current Coal and Coke Data for Publication, which is organized into the major functions or activities of the industries (production, distribution, etc.). Because the availability of volumetric (quantity and quality measurements) and economic (pricing and financial information) data varies among coal activities, these two types of data will be presented separately under each activity or function. The data included on the table are:

- Source or sources of data

- Periodicity of data source

- Length of time between end of last day in report period and 100 percent submittal of data by respondents (time lag)

- Universe coverage

- Advantages and disadvantages of use in the QCR.

Potential data sources for the OCR were identified through interviews with OCEPS representatives (Noel Balchasar, Robert Harris), research guided by the listing of data collection forms found in the EIA Publications Directory, and source references found in EIA publications. 
Table 2. Availatility of Cidrient Coal and Coke Jata for Publication

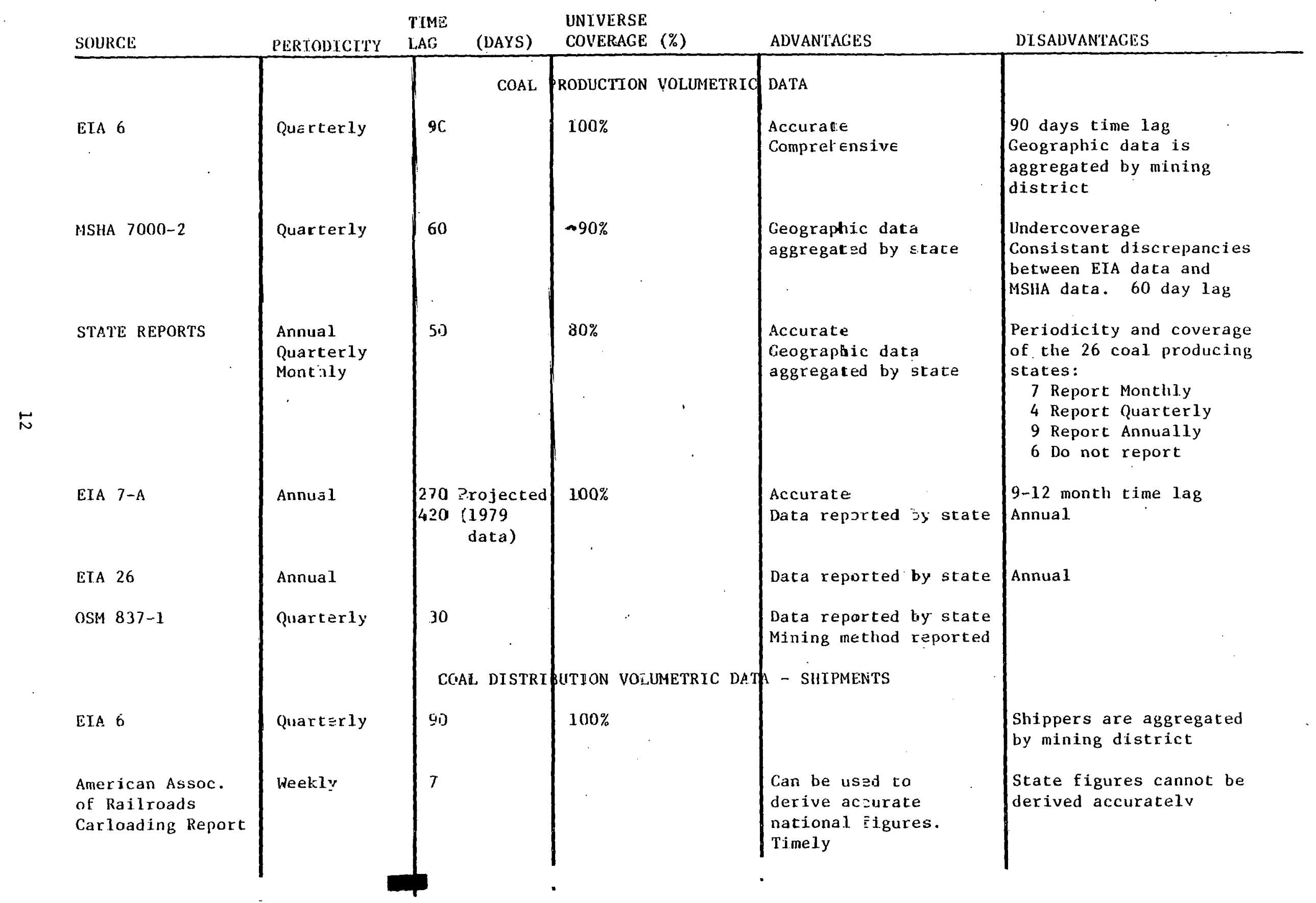


Table 2 continued.

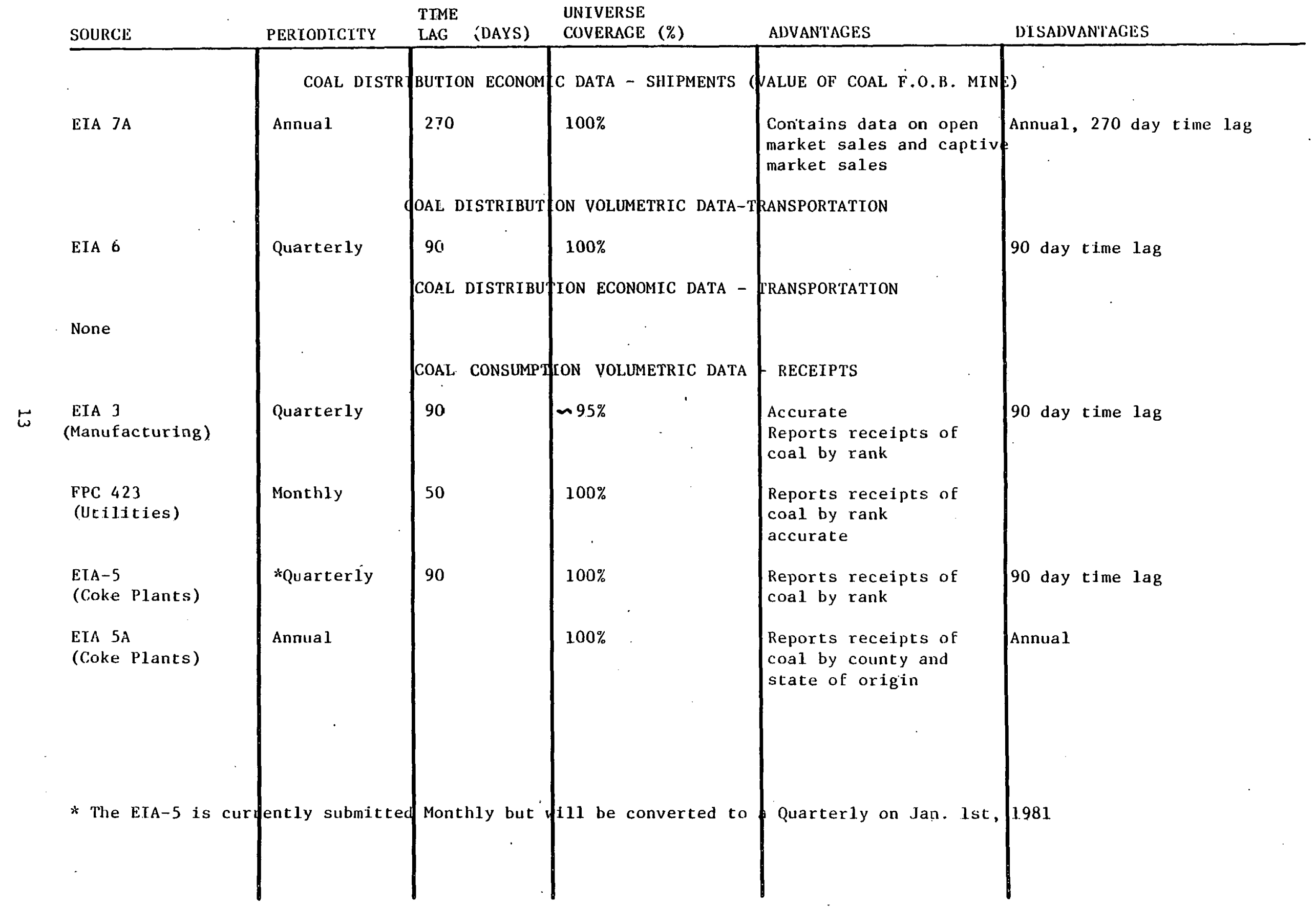


lable 2 continued.

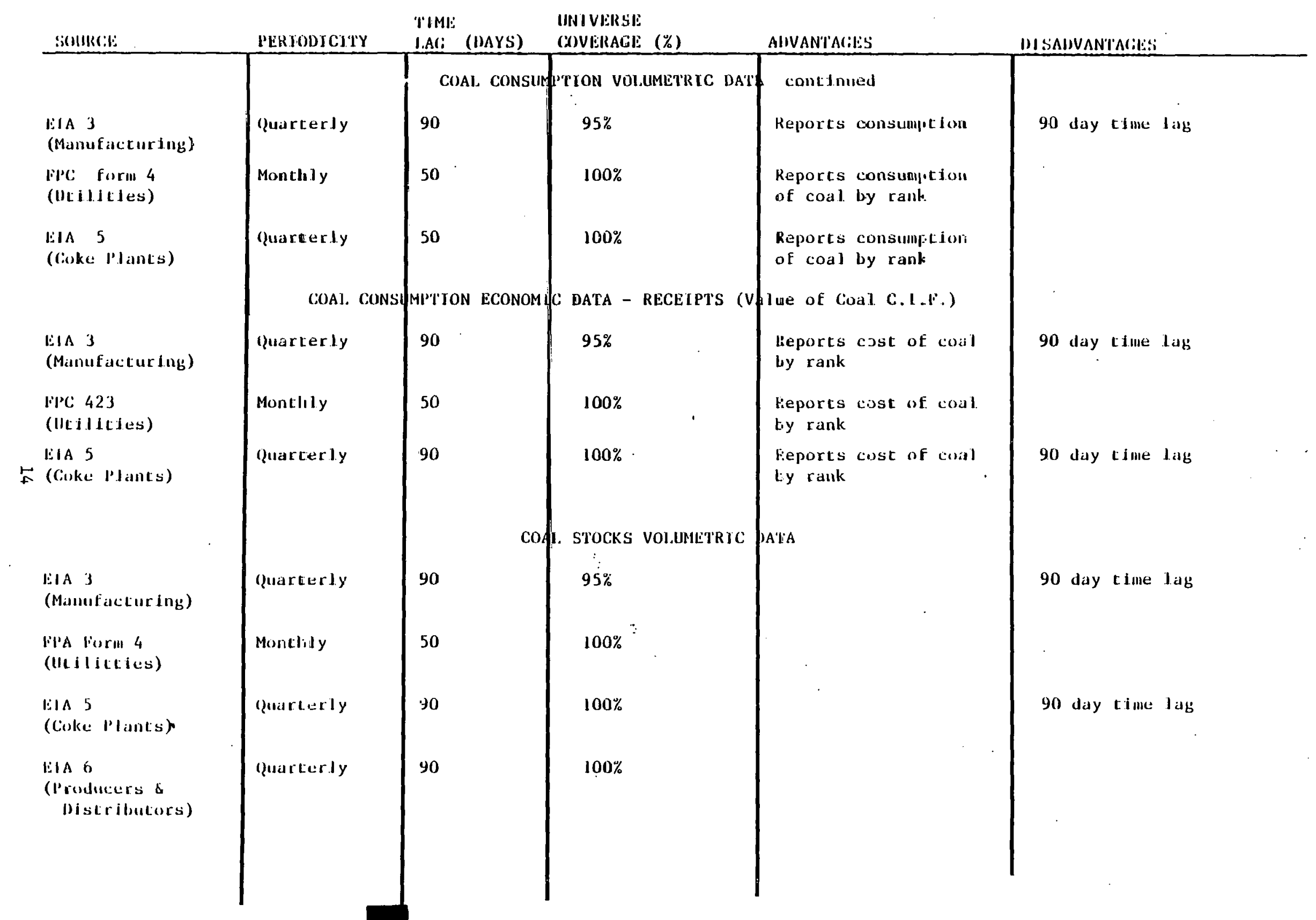


Table 2 continued.

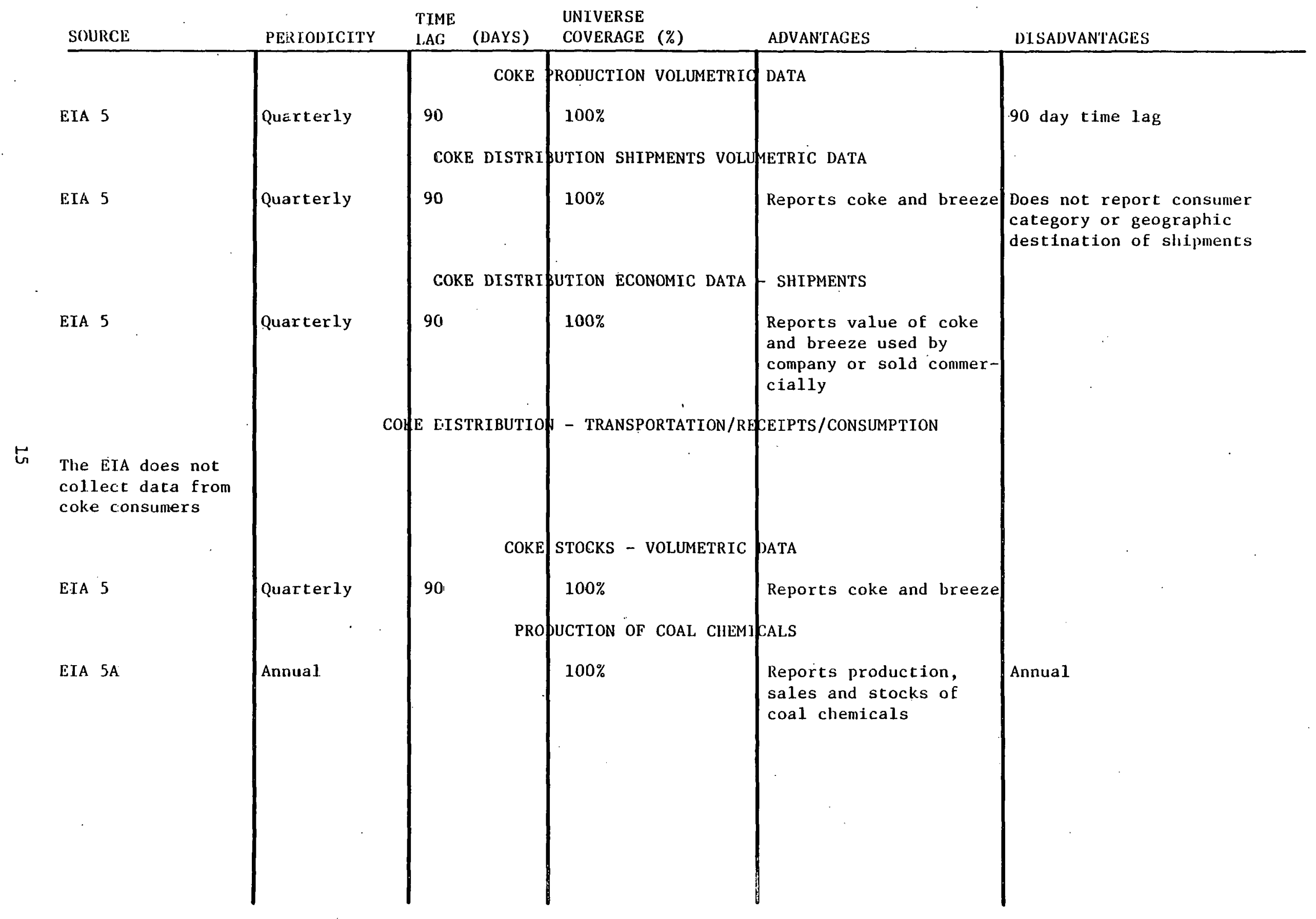


Table: 2 continued

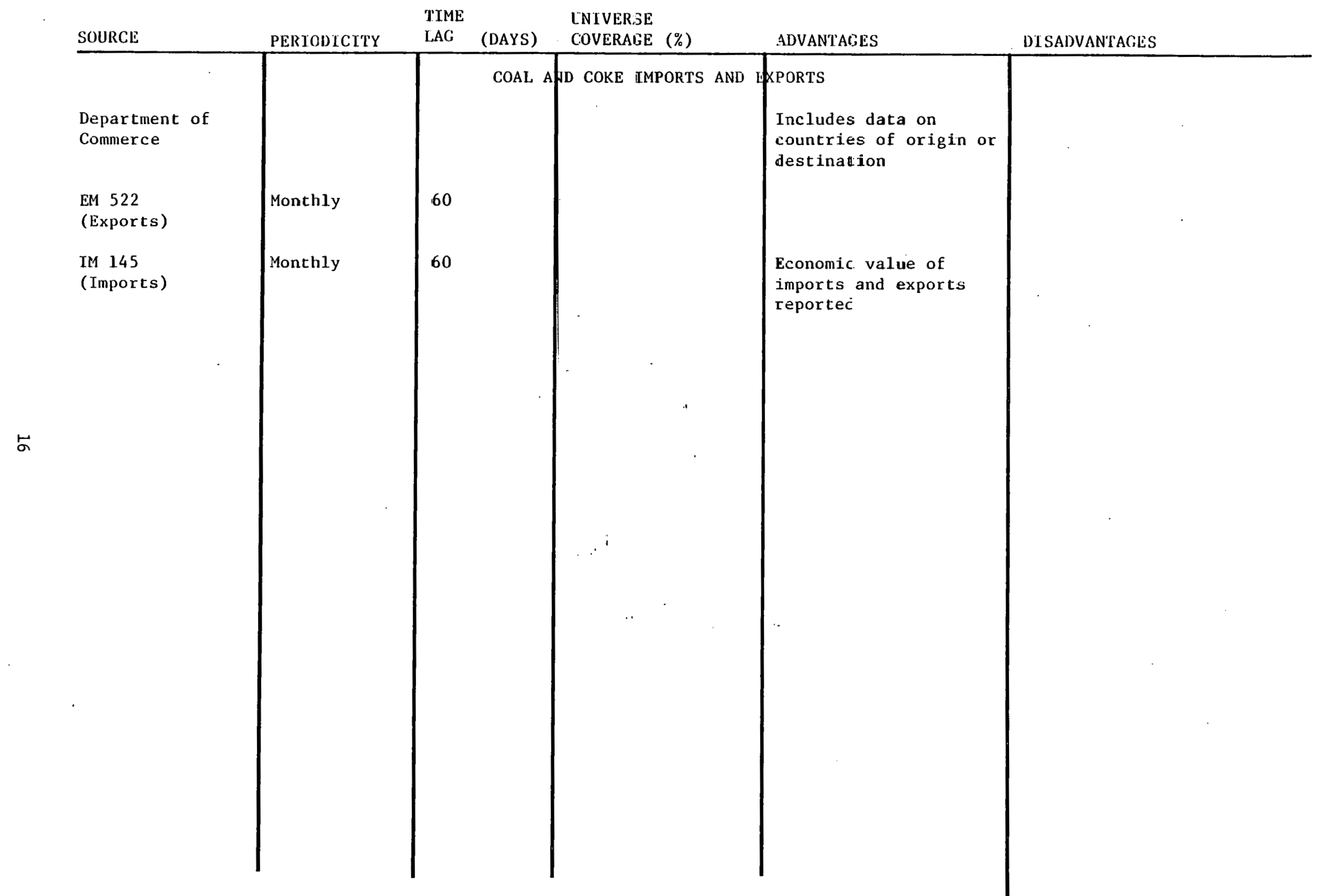




\section{Analysis}

The purpose of a summary coal and coke publication is to consolidate and present the most accurate, available volumetric and economic data collected on the supply and demand of coal and coke. In an earlier section, the supply and demand process was represented through the use of a balance equation. The individual elements of this equation were then analyzed to determine the functions that should be represented in a summary coal publication. This section consisted of an analysis of these functions and the available data on each function. The results of this analysis permit conclusions to be drawn concerning the content of a comprehensive statistical summary coal and coke presentation.

Coal Volmetric Data

Primary data (collected via a DOE collection instrument) exist and can be published for each major function within the coal supply and demand process. The majority of currently collected-data are consistent as to geographic aggregation (state), units of measure (short tons), and universe coverage (100 percent complete). One major exception is data on shipments which are aggregated by producing district rather than by state. Currently, there is no alternative source for shipment data by state. Production and distribution data combine all four ranks of coal (bituminous, subbituminous, lignite, and anthracite) into one total figure. However, receipts, consumption, stocks and import/export data are broken down by rank.

Coal Economic Data

Value of coal shipped data (F.O.B, mine) are currently collected on an annual basis. Transportation cost data are not currently collected by EIA. Consumer cost data of coal (C.I.F.) are available for utilities, coke plants and manufacturers. Import and export values are also available. 
Coke Volumetric Data

Coke volumetric data exist for production, shipments, stocks, imports and exports. Coke consumer receipts, consumption and stocks data are not collected by EIA. Data are available for coal chemical but strictly on an annual basis. Coke and breeze data are collected quarterly.

Coke Economic Data

The economic data available on coke are the commerrial, sales value and value of imports and exports.

Publlcation Perindirity

As evidenced by the preceding grids, the majority of data on the supply and dcmand of cual is cullected. Theretore, a sumary coal and coke publication can be published on a quarterly, semi-annual or annual basis to accomodate the timeframe limitations of the data currently collected. Since one of the primary requirements of data users is timeliness, a quarterly publication is recommended. 


\section{Analysis of the Proposed Quarterly Coal Review}

This section contains the results of our analysis of the proposed contents of the quarterly coal publication. In this section we describe each part of the publication and present issues regarding the content and format.

The information presented in this section is based on the user interviews, the review of the coal industry and the analysis of current data collection activities which were highlighted in the previous three sections of this report. The section is organized into three parts. They are:

- Analysis of Front and End Materials

- Analysis of Data Presentation

- Summary List of Tables and Graphs.

\section{Analysis of Front and End Materials}

In the following paragraphs we describe and make recommendations for presenting those portions of the quarterly coal publication which preceed or follow the statistical presentations.

Publication Title

It is our conclusion that naming the publication The Quarterly Coal Review may be misleading to the user community. The content of the publication could include data on coke as well as coal and the tables, charts and few explanatory notes which make up the content of the publication do not fit the commonly held concept of a review. Consequently, we recommend that alternative titles for the publication be considered such as Coal and Coke Quarterly or Coal Quarterly. 
Front Materials

Executive Summary. Many EIA publications have a short summary that appears prior to the main text of the report. Such summaries are especially useful for readers with little time to examine the detailed contents of a publication. It is our conclusion that a summary of this type can be useful in a quarterly statistical publication.

There are inconsistencies among current EIA publiçations concerning the title of a beginning summary section. Some publications contain a section called "Summary" while others use the word "Highlights." However, according to the EIA Publications Manual, Volume 1, summaries and highlights should be called "Executive Summary." The Executive Sumnary can preview the more substantive highlights of the publication, using mostly national figures and can highlight signiflcant increases or decreases in national totals. The amount of change should be expressed in percentages as well as in absolute figures.

As an enhancement or alternative to the Executive Summary, a table or tables of salient statistics can be included. The Monthly Finergy Review and the Coke and Coal Chemicals Annual both feature summary tables that provide an effective introduction to the publication.

Scope of Publication. EIA publications of ten include information on:

- Purpose

- Data Limitations

- Coverage.

Discussed in the preface, introduction or foreword sections, this information is important to know prior to a review of the substantive material. These sections can be efficiently combined in a short "Scope of Publication" statement, preceding the data presentation. 
End Materials

Many EIA publications contain ending materials including data which improve understanding of the text. These include a glossary of terms, explanatory notes or other short notes. Although not usually included in EIA publications, an abstract of the data sources used for the content of the QCR could provide valuable insights on data availability, limitations and collection procedures.

\section{Analysis of Data Presentation}

This section of the report contains analyses of both general and specific issues concerning presentation of coal and coke data. These issues are:

- Presentation of Coal and Coke Data

- Presentation of Economic and Volumetric Data

- Identification and Ordering of Subject Sections

- Presentation of Monthly and Quarterly Data

- Geographic Aggregations

- Presentation of Coal Consumer Data

- Presentation of Distribution Data

- Presentation of Coal and Economic Data

- Presentation of Coke Data.

Presentation of Coal and Coke Data

Although coke plants are major consumers of coal, their products - coke, breeze and coal chemicals - are not an integral part of the supply and disposition of coal. For this reason, and due to the comparatively small amount of coke data collected, it is questionable whether these data should be included in a summary coal publication. However, if a decision is made that coke data should be included in the $\underline{Q C R}$, we have identified three options for their display.

Presentation of Coke Data with Coal Data. Under this option coal and coke production data are presented in one section of the $Q C R$, stocks in another and so forth. This integrated presentation of coal and coke data may, however, impede comprehension of the separate supply and demand flows of coal and coke. 
Presentation of Coke and Coal Data Separately. This method of presentation divides all coke and coal data between one large section (coal) and one small section (coke). The supply and demand flows, which differ for coal and coke, can be more easily followed by users.

Presentation of All Coke Data in an Appendix. Very little data on coke are available in comparison to what is collected on coal. Therefore, coke data will occupy only a few pages in the QCR and could be placed in an appendix. Although use of this option will completely separate coal and coke data, appendices in EIA publirations usually conoist of glusseries, çonversion tables, etc. and do not include statistical presentations.

Presentation of Economic and Volumetric Data

As shown in the previous section titled "Analysis of Coal and Coke Data Cullection Activities;" there are relatively little economic data collected. Although the separation of these data from volumetric data was considered, it is our conclusion that economic data would be better displayed within each applicable section. Economic data can either be placed in a table along with the volumetric data or displayed on separate tables following the presentation of volumetric data.

Identification and Ordering of Subject Sections

In a previous section of this report titled "Major Functions of the Coal and Coke Industries", we identified the energy functions that are applicable to a sumary coal and coke publication. The sections (or chapters) of the QCR should correspond to these functions. There are a number of options for ordering these sections, but comparability of data is improved where sections follow a balance or flow such as described in Section 2. According to this equation, there are two options for ordering. Both options assume that coles data will be included as a separate non-appendix section of the publication. 
The first option is:

$\underline{\text { Coal }}$

Production

Stocks

Net Exports

Distribution

\section{Coke}

Production

Imports

Net Exports

*Distribution

Consumption

*The only coke distribution data available are open market and captive sales.

The second option is:

$\frac{\text { Coal }}{\text { Supply }}$
$\begin{aligned} & \text { Production } \\ & \text { Stocks } \\ & \text { Imports } \\ & \text { Demand }\end{aligned}$

Exports

Distribution

Consumption
Coke

Supply

Production

Stocks

Imports

Demand -

Exports

Distribution

The use of either of these options will present the data in the QCR in a logical manner and enhance the comparability of data between sections.

Presentation of Monthly and Quarterly Data

The majority of data that are recommended for inclusion in the QCR are, or will be, as in the case of the EIA-5 coke survey, collected quarterly. Some data, such as utility stocks, consumption, imports, and exports are presently collected monthly. Due to this inconsistency, it is necessary to discuss the eime intervals under which the data will be displayed.

One option is to present the data as either a quarterly total or as three monthly figures, depending on how it is collected. Quarterly total columns can be added to monthly tables to factlitate monthly and quarterly comparisons 
(see numbers 1 and 2 in Table 3). Tables displaying monthly data (see number 2 on Table 3), however, will require 12 columns of data. To eliminate some of these columns, monthly data for the current quarter could be displayed by month, and historical data could be aggregated by quarter (see number 3 on Table 3).

Another option is to divide all quarterly data into monthly data. An example of this option is the use of an equation for "Other Industrial" coal consumption data in the Monthly Energy Review (MER).

"Given the estimated quarterly consumption for the 'Other Induscrial' sector $(C)$, the monthly consumption for the sector $\left(C_{m}\right)$ can be estimated for each month in the quarter as:

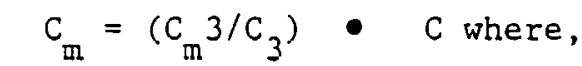
as reported on Form EIA-3.

$\mathrm{C}_{3}=$ the quarterly consumption in the 'Other Industrial' sector as reported on Form EIA-3.

Equation (3) insures that a) the monthly consumption estimates ( . $^{\text {) }}$ sum to $C$ over the quarter and b) the estimated seasonality for the $C_{m}$ 's is the same as that for the $C_{m 3}$ 's. " 
'lab1: 3. Al'TERNATIVE PRESENTATIONS OF MONIILY AND (qUAR'IERI,Y DA'I'A

1. Presentation by Quarter

$\begin{array}{ccc}\begin{array}{c}\text { Current } \\ \text { Quarter }\end{array} & \begin{array}{c}\text { Previous } \\ \text { Quarter }\end{array} & \begin{array}{c}\text { Quarter } \\ \text { Previous Year }\end{array} \\ \begin{array}{c}\text { Jan.-Mar. } \\ 1980\end{array} & \begin{array}{c}\text { Oct. - Dec. } \\ 1979\end{array} & \begin{array}{c}\text { Jan. - Mar. } \\ 1979\end{array}\end{array}$

2. Presentation by Month

$\begin{array}{cccc}\begin{array}{c}\text { Current } \\ \text { Quarter }\end{array} & \begin{array}{c}\text { Previous } \\ \text { Quarter }\end{array} & \begin{array}{c}\text { Quarter } \\ \text { Previous Year }\end{array} \\ \text { Mar. Feb. Jan. Total } & \text { Dec. Nov. Oct. Total } & \text { Mar. Feb. Jan. Total } \\ 198019801980 & \text { Quarter } 197919791979 & \text { Quarter } & 197919791979 \text { Quarter }\end{array}$

3. Presentation by Month and Quarter.

$\begin{array}{ccc}\begin{array}{c}\text { Current } \\ \text { Quarter }\end{array} & \begin{array}{c}\text { Previous } \\ \text { Quarter }\end{array} & \begin{array}{c}\text { Quarter } \\ \text { Previous Year }\end{array} \\ \text { Mar. Feb. Jan. Total } & \text { Oct.- Dec. } & \text { Jan. - Mar. } \\ 19801980 \text { 1980 Quarter } & 1979 & 1979\end{array}$

$1980 \quad 1980 \quad 1980 \quad$ Quarter

ct.- Dec.

1979 
As explained in the MER, this equation divides quarterly figures by three to derive estimated monthly figures. These figures are then adjusted according to historical trends prior to publication. This accounts for the variations that appear between months in the same quarter.

As stated previously, the majority of data which are to be included in the quarterly coal publication is collected on a quarterly basis. Therefore, if data are to be consistently presented as monthly figures, the majority of the figures which appear on tables will be estimates.

A third option is to present all data as quarterly figures by consolidating monthly figures. Of the three options, this is the easiest and most consistent approach.

Geographic Aggregations

The EIA currentily uses a number of geographic aggregations in the publication of national coal and coke data (see I1lustrations 1 and 2 ). These are:

- Census Region and State

- Coal Producing District

- Coal Producing Area

- Coal Producing Region.

The geographic aggregations available for potential use in the QCR are determined by the collection and subsequent aggregation of data from current EIA coal and coke data collection forms. These are: 

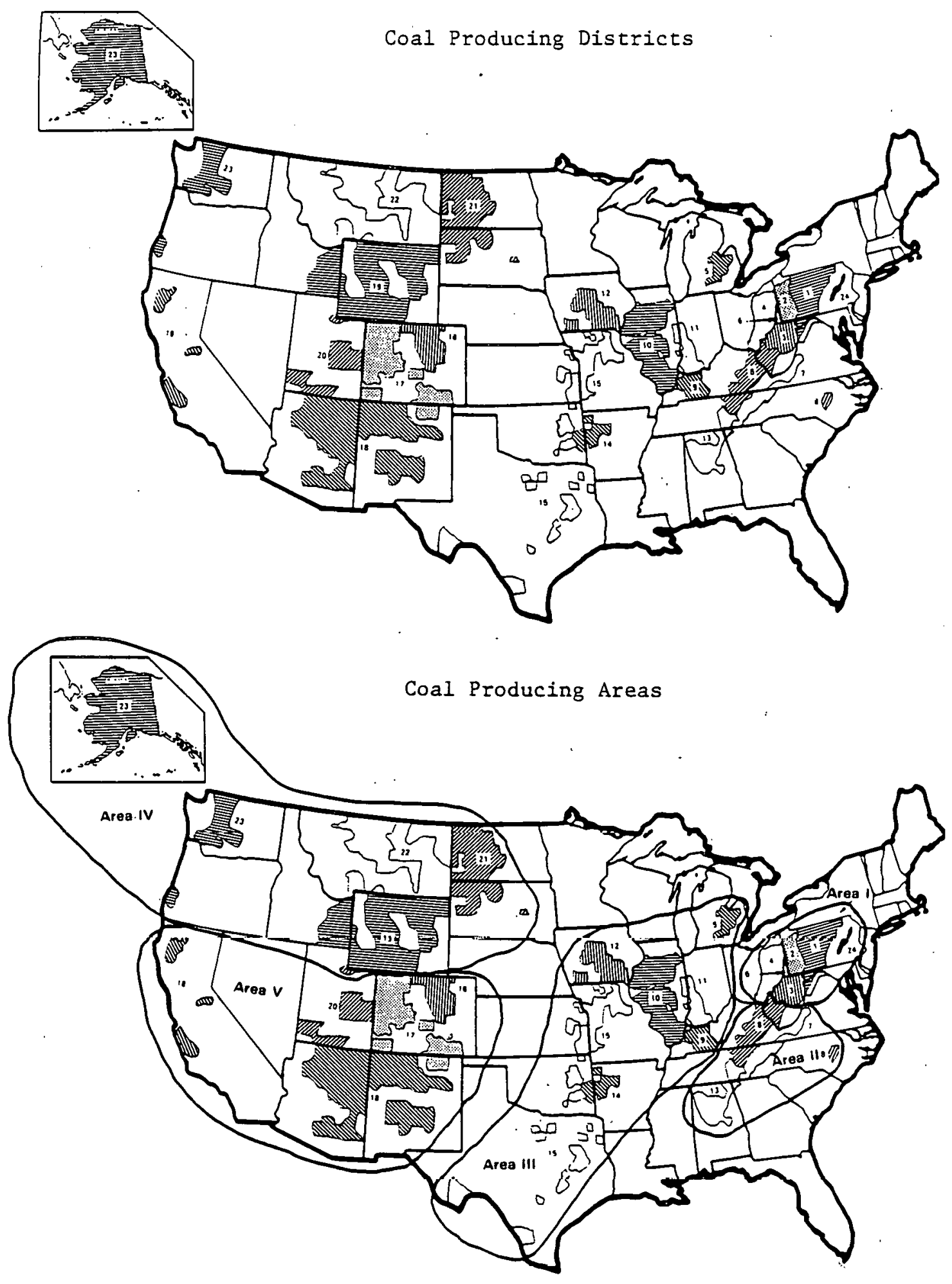

Illustration 1. Maps of Coal Producing Districts and Coal Producing Areas 

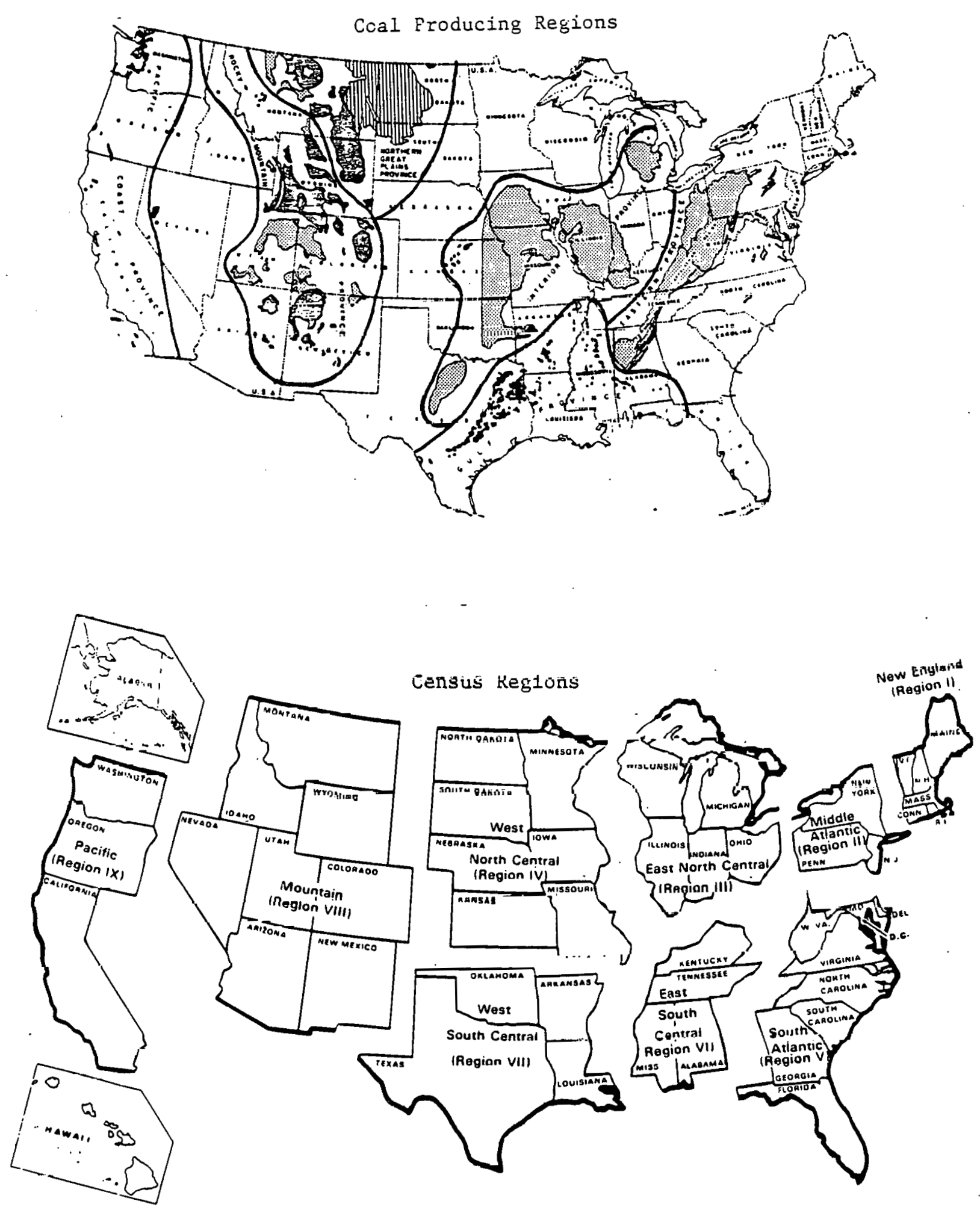

Illustration 2. Maps of Coal Producing Regions and Census Regions 


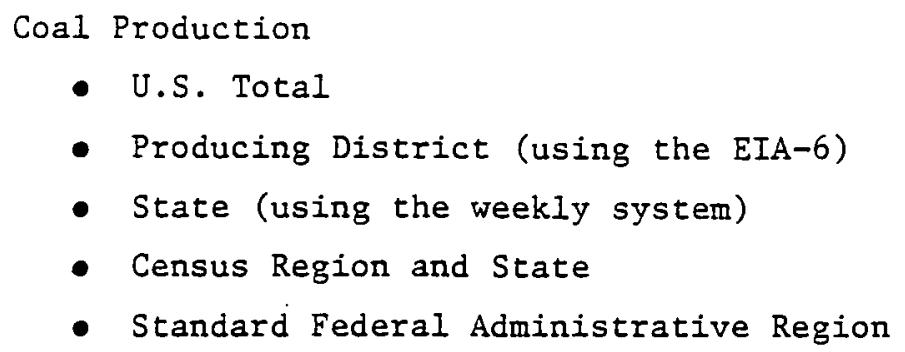

- State

- Census Region and State

- Standard Federal Administrative Region

Coal Distribution

- U.S. Total

- Producing District

Coal Receipts and Consumption

- U.S. Total

- State

- Census Region and state

- Standard Federal Administrative Region and State

Al1 Coke Data

- U.S. Total

- Slate

- Census Region and State

- Standard Federal Administrative Region and State

In our analysis we discovered that the grouping of coal data users by census region is not important to users. What is important to users is the presentation of state data. A recommended option is, therefore, to present state data without the census region aggregations (Appendix D summarizes the geographic aggregations used in a variety of EIA publications. Note that the census region aggregation is seldom used.) 
Standard Federal Administrative Regions. The Standard Federal Administrative Regions consist of groupings of states that are roughly similar to census regions. (See Illustration 3) According to Directive No.6, Office of Federal Statistics and Policy Standards (DOC):

"Agencies which publish regional data compiled from information published by State and the District of Columbia shall as soon as possible publish these data on the basis of the ten Standard Federal Regions..."

Each of these ten regions are supervised by a Federal Regional Council. These councils fulfill three roles:

- Interagency coordination of federal programs affecting states,

- Promotion of better relations between federal and local offices and

- Under the Carter administration, analysia of the impact of programs on rural and urban areas.

The purpose of Directive No. 6 is to make data available to these councils in comparable geographic aggregations.

Although Directive No. 6 directs that all state data be aggregated by Federal Administrative Region, its adoption by "EIA should be considered sarefully. According to Milo sundcrhauf of the Office of Fedeial 3latislics and Policy Analysis, "the usefulness of compiling state data this way should be reviewed." His recommendation was that data be displayed in aggregations which are useful to the largest part of the intended audience.

Sunderhauf's opinion was that the Federal Regional. Counrils, althnugh still functioning, were diminishing in importance.

Dick O'Brian of the Office of Management and Budget called Sunderhauf's statement highly subjective, but said that, to his knowledge, very litt.le data are published by Federal Administrative Region. .

Due to the confusion surrounding the importance of the Federal Administrative Council and the limiled amount of dara published by Administrative region, reaggregation by Federal Administrative Region should not be done without careful consideration. We do not recommend the aggregation of coal data by Federal Administrative Region. 


\title{
DIRECTIVE NO. $6^{\circ}$
}

\section{STANDARD FEDERAL ADMINISTRATIVE REGIONS}

\begin{abstract}
hgencies which publish regional data compiled from information published by States and the District of Columbia shall, as soon as practicable, publish these data on the basis of the ten Standard Federal Administrative Regions as established by the President and set forth in OMB Circular No. A-105, April 4, 1974. The names of the States composing each region are presented below.
\end{abstract}

Standard Federal administrattve Regions Region I-Connecticut, Maine, Massachusetts, New Hampshire, Rhode Island, and Vermont

Region II-New York, New Jersey, Puerto Rico, and the Virgin Islands

Region III-Delaware, District of Columbia, Maryland. Pennsylvania, Virginia, and West Virginia

- Directive No. 6 supersedes section $7(g)$ and Exhibit D of OMB Cireular No. A 46 dated May 3, 1974.
Region IV-Alabama, Florida, Georgia, Kentucky, Mississippi, North Carolina, South Carolina, and Tennessee

Region V-Illinois, Indiana, Michigan,

Minnesota, Ohio, and Wisconsin

Region VI-Arkansas, Louisiana, New Mexico, Oklahoma and Texas

Region VII-Iowa, Kansas, Missouri, and Nebraska

Region VIII-Colorado, Montana, North

Dakota, South Dakota, Utah, and Wyoming Region IX-American Samoa, Arizona,

California, Guam, Hawaii, and Nevada

Region $\mathbf{X}$-Alaska. Idaho, Oregon, and Washington

Agencies may also putlish data for regions composed of different groupings of States whenever necessary for special analytical purposes or to maintain continuity of historical series.

\author{
Illustration 3. Office of Federal Statistics \& Policy Standard \\ Directive No. 6
}


Presentation of Coal Consumer Data

The Coal Distribution Report, or EIA-6, is used to collect data on shipments of coal, including their geographic destination and type of consumer receiving coal. There are seven categories listed on the EIA-6. These are:

- Electric Utilites

- Coke Plants

- Agriculture, Mining and Construction

- Manufacturing

- Residential/Commercial

- Transportation

- Unknown/Not Revealable

Of these categories, electric utilities and coke plants account for more than 90 percent of coal shipments. Manufacturing, agriculture, mining and construction account for an additional 8 percent while transportation and residential/commercial consumers account for less than 2 percent (Coal Distribution Quarterly Jan-Mar 1980).

Although data on each type of consumer is important, consolidation of some of the smaller consumer categories may improve the nverall presentation of these data in the QCR. The seven lategurles listed above could be merged into the following four categories.

- Electric Utilities

- Coke Flarils.

- Other Industrial (including manufacturing agriculture, mining and construction, transportation and unknown/not revealable)

- Residential/Commercial

These consumer categories are consistent with those used in the Coal Distribution Quarterly and the Monthly Energy Review and will significantly simplify the presentation of these data. 
Of the four merged consumer categories only two, electric utilities and coke plants, have 100 percent respondent coverage on current EIA information systems. Approximately 90 percent of the category, Other Industrials, are zurrently surveyed. Residential/Commercial consumers, which account for approximately 1 percent of coal shipments, are not represented on any form. Two options exist for presenting Other Industrial and Residential/Commercial data in the receipts, consumption and stocks sections of the $Q C R$.

The first option is to estimate part or all of the missing data, based on shipment data taken from the EIA-6 Coal Distribution Report. This method is currently being used in the Monthly Energy Review.

A second option is to report only those data which are actually available to EIA, thereby excluding data on receipts, stocks and consumption for residential/commercial consumers.

Presentation of Coal Distribution Data

The distribution section should contain three types of data. These are:

- The amount of coal shipped from coal producing districts of the U.S. during a period of time

- The method of transportation

- The destination of shipments, including consumer category by state.

A central issue concerning the distribution section is what type of data presentation will most clearly and efficiently depict the relationship between the three types of distribution data. 
The potential breakdowns for distribution data are listed below:

SHIPMENT

- 24 Mining Districts (The EIA-6, which is the only source for shipment data, reports the locations of the shipper by producing district. State data are not available.)
TRANSPORTATION

- Rail

- River

- Great Lakes

- Tidewater Piers

- Truck

- Tram Cuivieyur

- SIurry ripeline
DESTINATION

- State

- Foreign (If exports are included in this section)

- Electric Utilities

- Coke Plants

- Drher Induotrial (including manufartiring, agritullurL, mining, construction, transportation and unknown/not revealable)

- Residential/Commercial

Of the 7 methods of transportation listed above, 3 - rail, river and truck account for 90 percent of domestic coal transported. Tram conveyor and slurry pipeline, when combined account for 9 percent while Great Lakes and tidewater piers and coastal ports account for less than 3 percent (CDQ, Jan-Mar, 1980). The consistency of data presentation throughout can be enhanced if these 7 methods are consolidated into 4 major categories. Suggested categorles are:

- Rail

- Water (including river, Great Lakes and tidewater piers)

- Truck

- Other (including tram conveyor, slurry pipeline and unknown/ not revealable).

These categories are currently used in the Coal Distribution Quarterly publication. Several potential methods of displaying shipment data are listed in Table 4. The simplest format is to present each type of data separately. The most complex presentatinn identifies the geographic origin of each ton of coal shipped and the method of transportation used in each state. 
Table 4. Types of Data Display for Shipment and Transportation Data

- Shipments of Coal by Coal Producing District

- Shipments of Coal by Method of Transportation

- Shipments of Coal by Geographic Destination

- Shipments of Coal by Consumer Category

- Shipments of Coal by Coal Producing District and Method of Transportation

- Shipments of Coal by Coal Producing District and Consumer Category

- Shipments of Coal by Coal Producing District, Geographic Destination and Consumer Category

- Shipments of Coal by Coal Producing District, Geographic Destination and Method of Transportation

- Shipments of Coal by Coal Producing District, Method of Transportation, Geographic Destination and Consumer Category 
Although both types of presentation are options, data on shipments, transportation and destination can be presented efficiently and comprehensively in the QCR through a series of both general and somewhat detailed tables: These are:

- Shipments of Coal by Coal Producing District

- Shipments of Coal by Method of Transportation

- Shipments of Coal by Geographic Destination

- Shipments of Coal by Consumer Calegory

- Shipments of Coal by Coal Producing District, Method of Transportation and Geographic Destination.

The Consumption section of the proposed QCR, will contain consumer category receipts data by state. The reader is able to review shipments and transportation data from the state level in the distribution section of the QCR and trace the flow within each state in the consumption section. 
Presentation of Coal Rank and Economic Data

Coal rank data (whether coal is anthracite, bituminous, subbituminous or lignite) and economic data (the value, price, or transportation cost of coal) are currently collected from electric utilities, coke plants and manufacturers. The rank and price of coal produced at, and shipped from, the mine are not collected on a quarterly basis. The cost of transportation and insurance are also unavailable.

Date concerning the cost and quality of fuels are of major importance to users of EIA publications. There are three alternative forms of display for these data:

- Average Spot and Contract Costs of Fuel by Rank

- Average Spot and Contract Costs of Coal by Rank and Consumer Category

- Average Spot and Contract Costs of Coal by Rank, Consumer Category and State.

The three alternative forms of data display listed above range from the general to specific. Of the alternatives, Average Spot and Contract Costs of Rank, Consumer Category and State, is the most specific since it is the only alternative that breaks down costs of coal by geographic boundary (State). Where applicable (i.e., one coke plant in one state), data should be aggregated into an "Unknown/Not Revealable" category to avoid disclosure of company data.

Display of Coke Data

Production, disposition and stocks of coke and breeze are collected on one quarterly form, the EIA-5. All data are aggregated by state. The value of coke sold or used by the respondents is also reported. Currently, EIA does not collect dara on the consumption of coke and breeze. 


\section{Summary List of Tables and Graphs}

This section of the report consists of a list of tables and graphs that can be used in the QCR (see Table 5). This list is not intended to be a rigid set of recommendations, but rather is provided as illustration of some of the data display options discussed in the previous section. All tables, except those marked with an asterisk, display the time intervals in the spanner. The intervals are (from left):

- Current Quarter

- Previous Quarter

- Quarter During Prior Year

- Current Year to Date

- Prior Year to Date

Tables with asterisks only present data for the current reported quarter. Proposed graphs will present units of measurement on the vertical and time intervals on the horizontal axes respectively. 


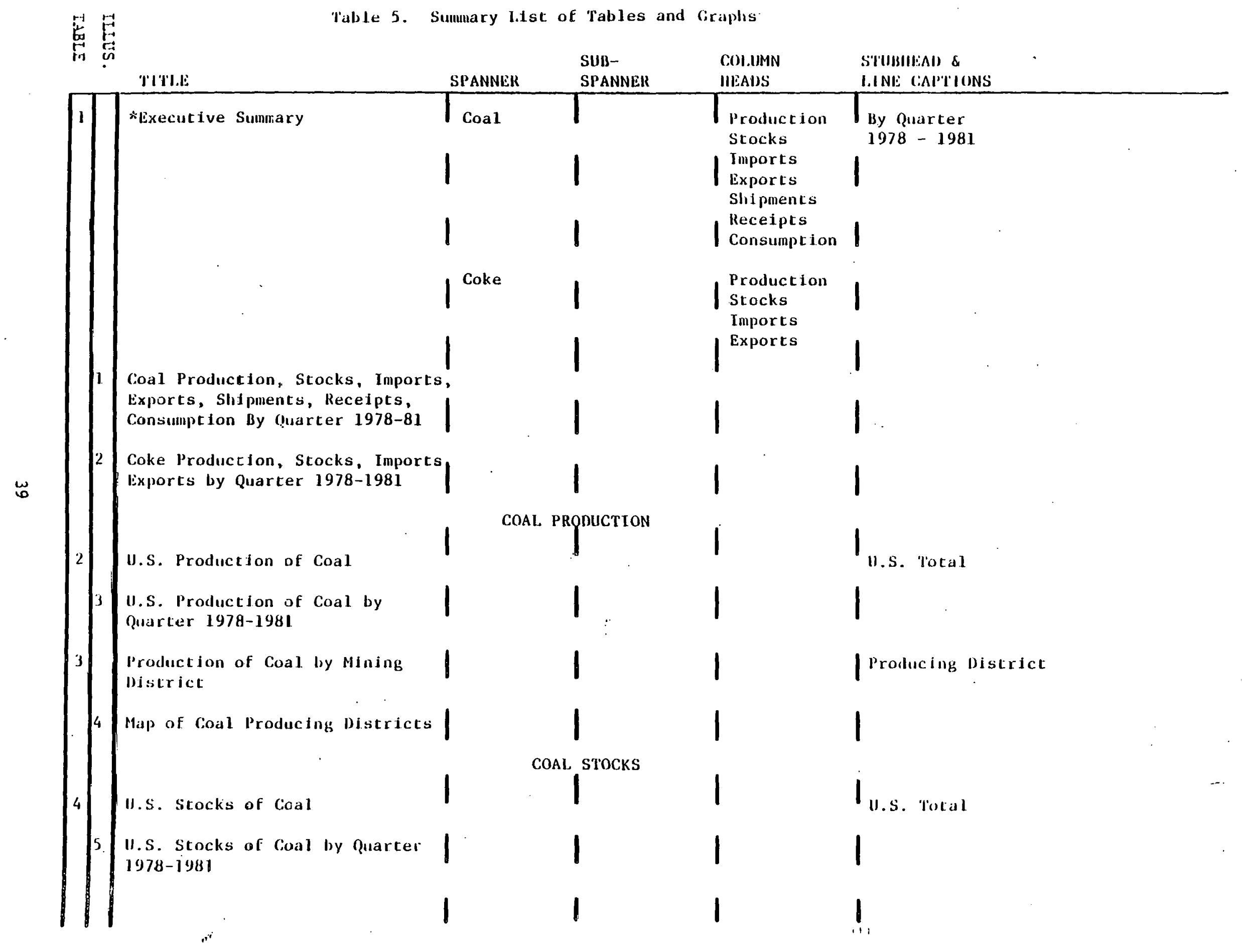




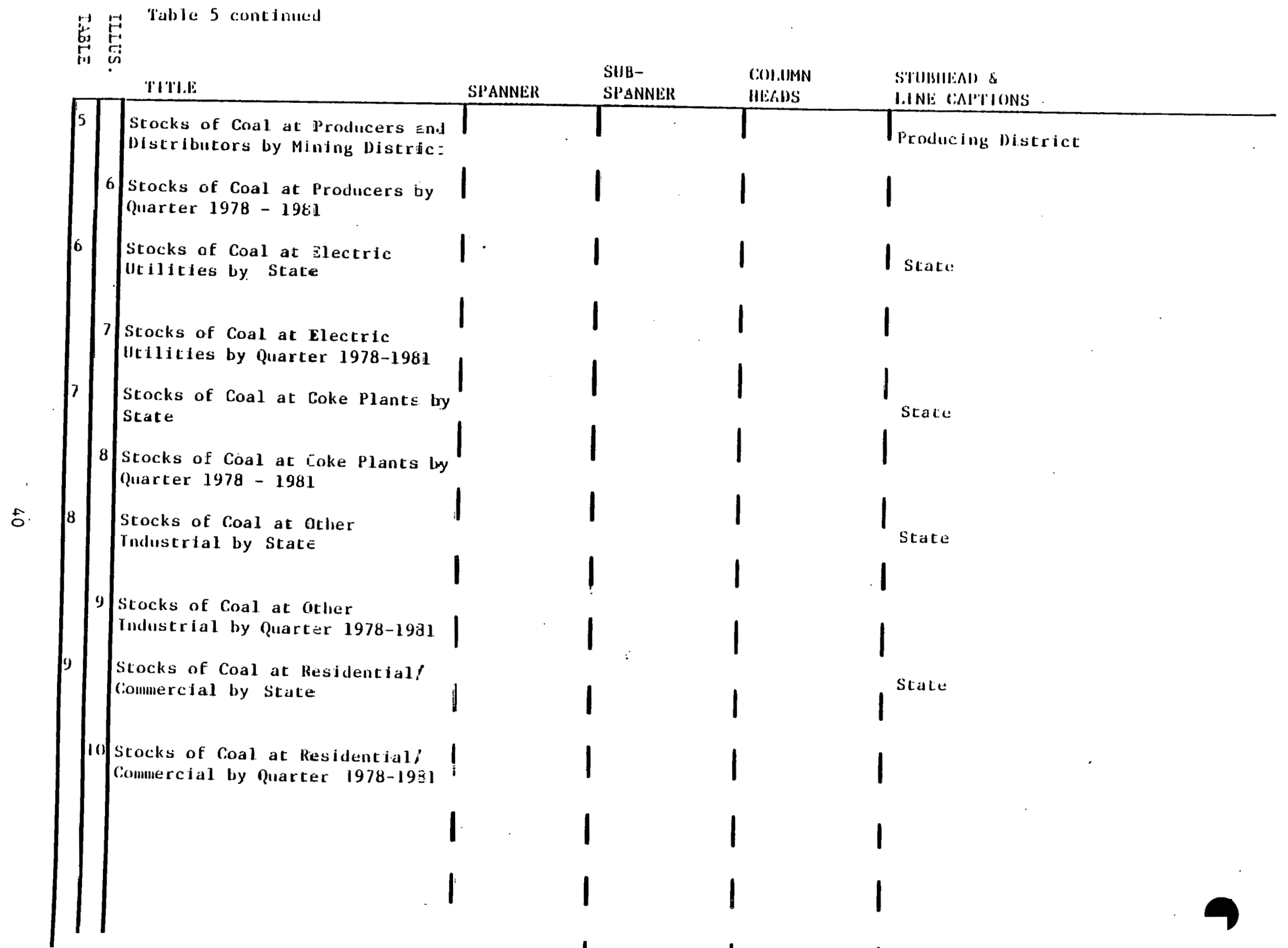




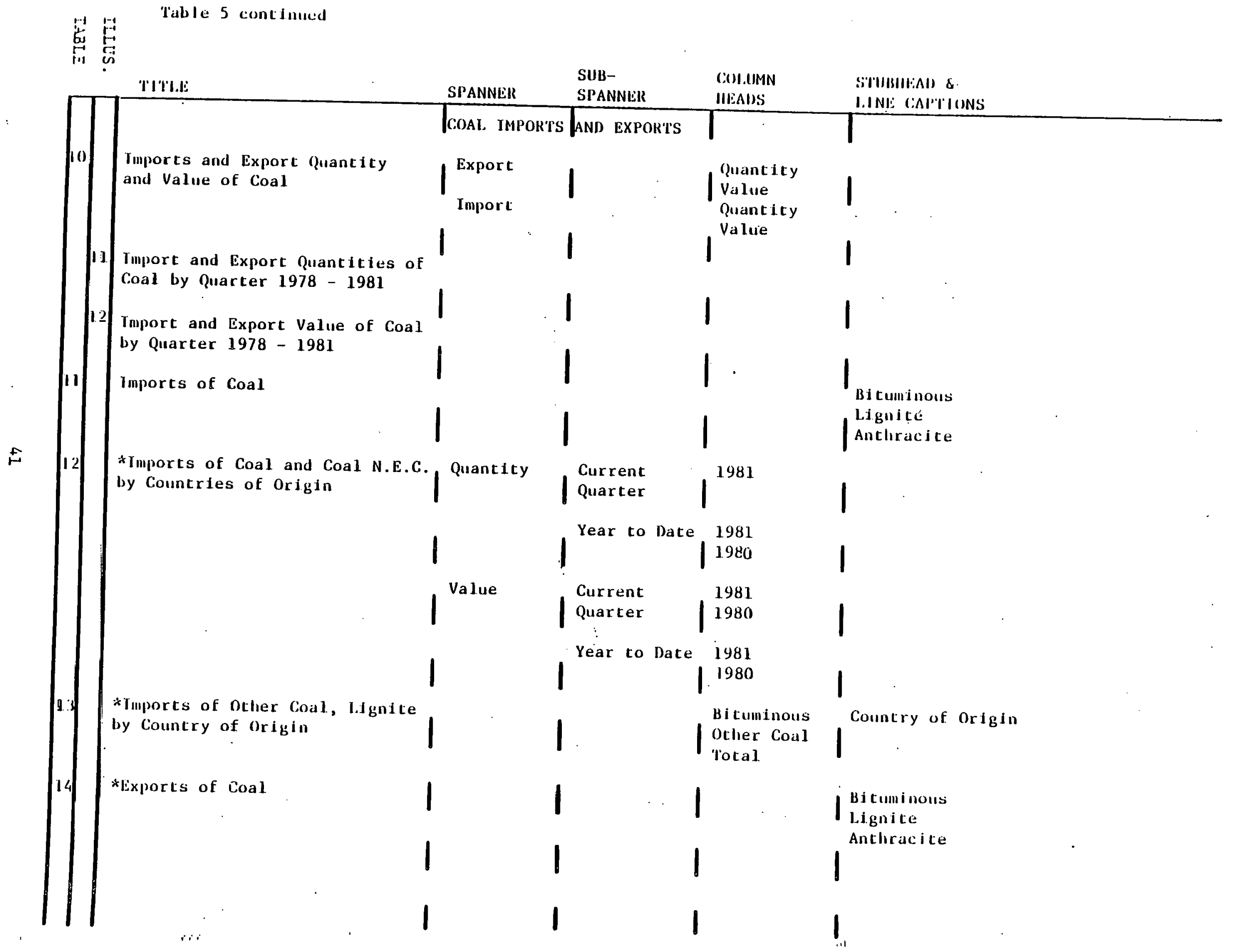




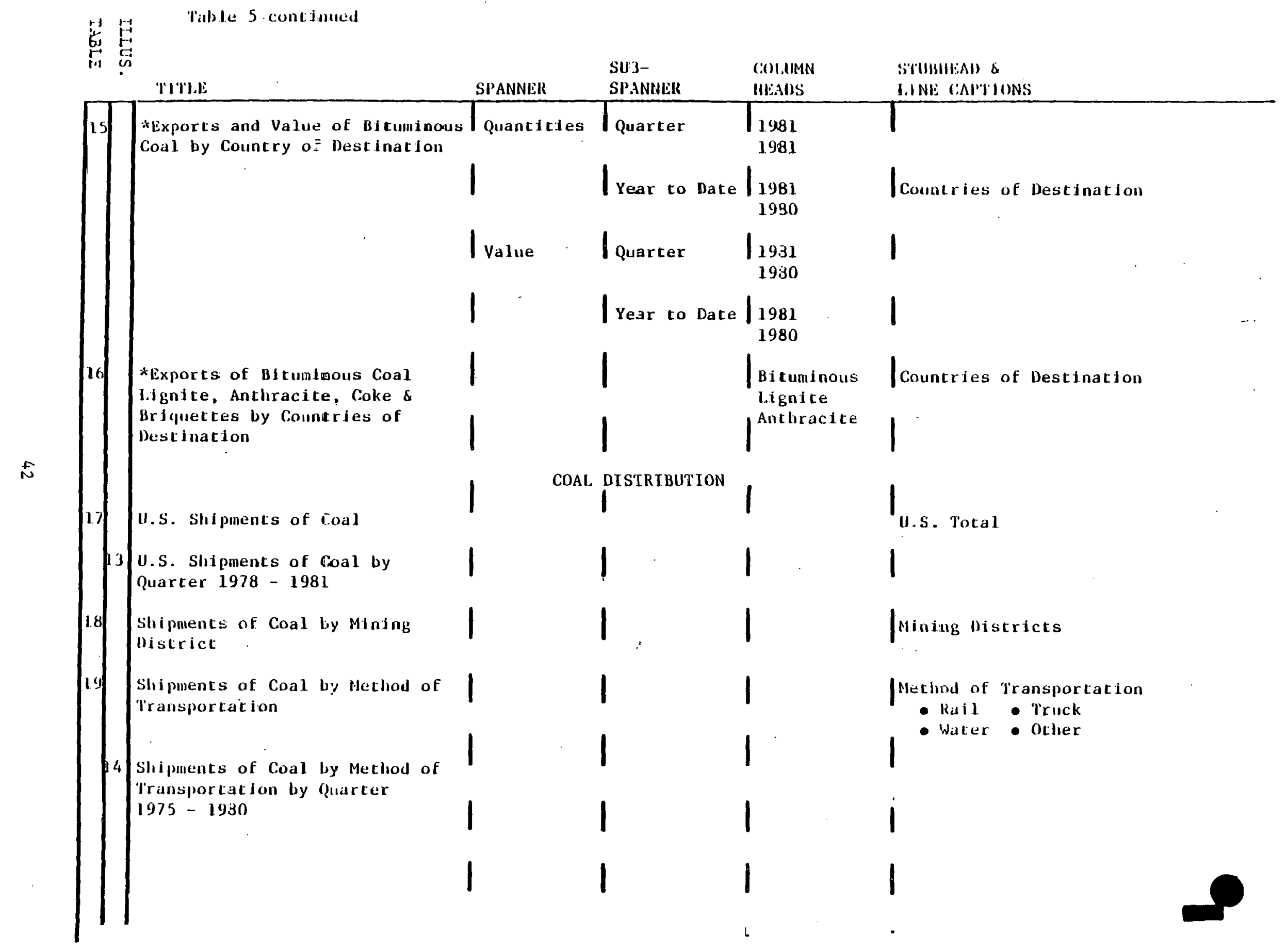




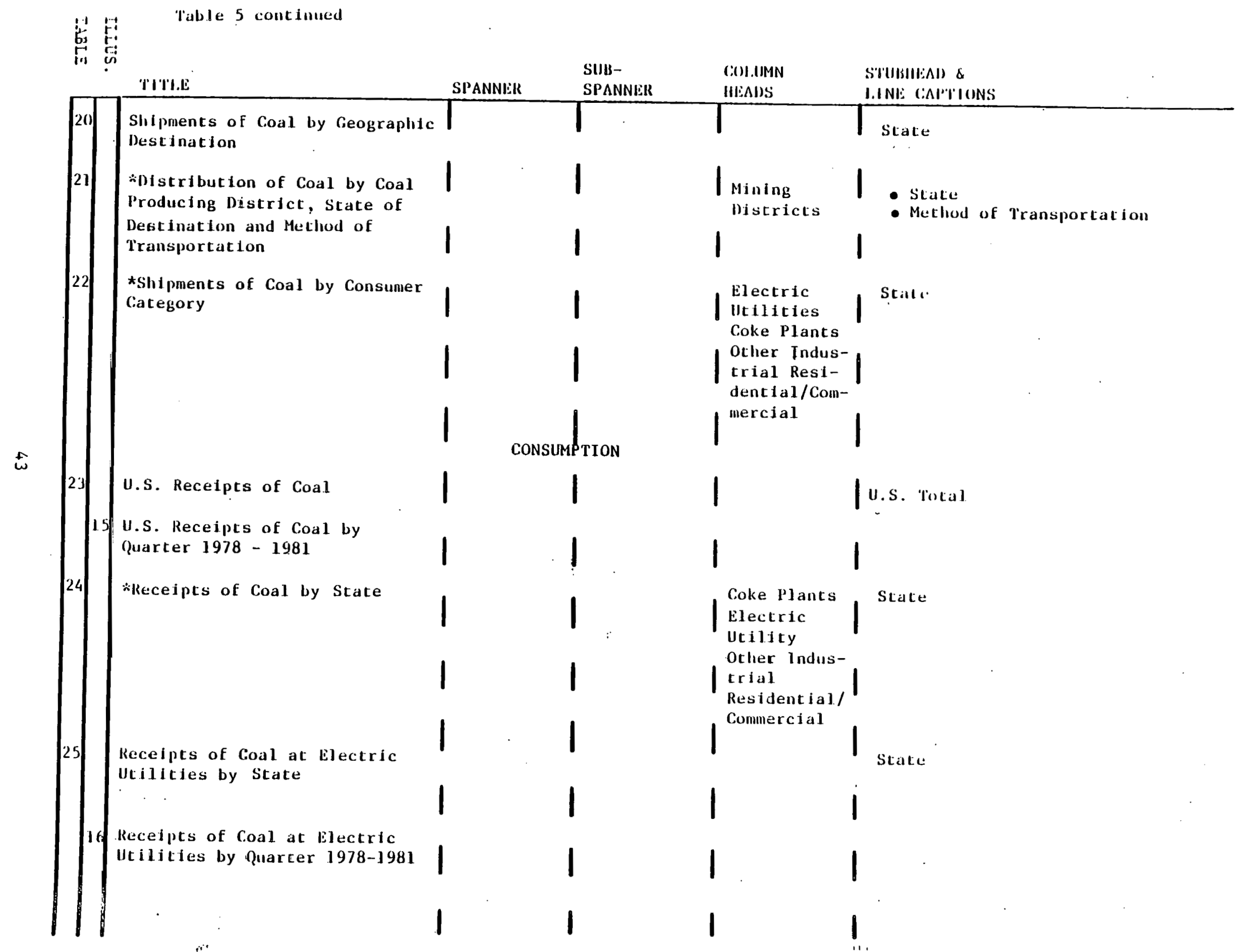




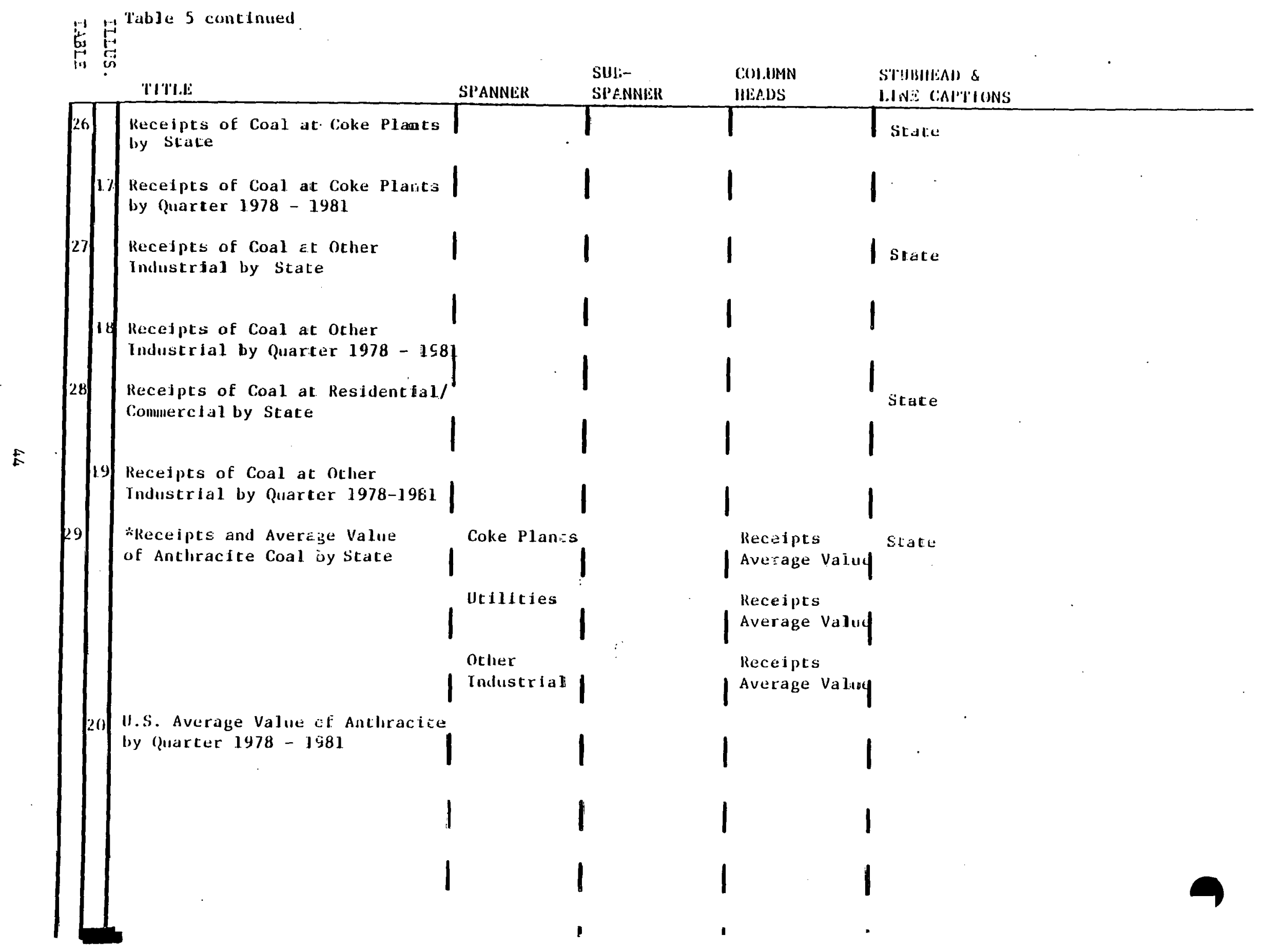




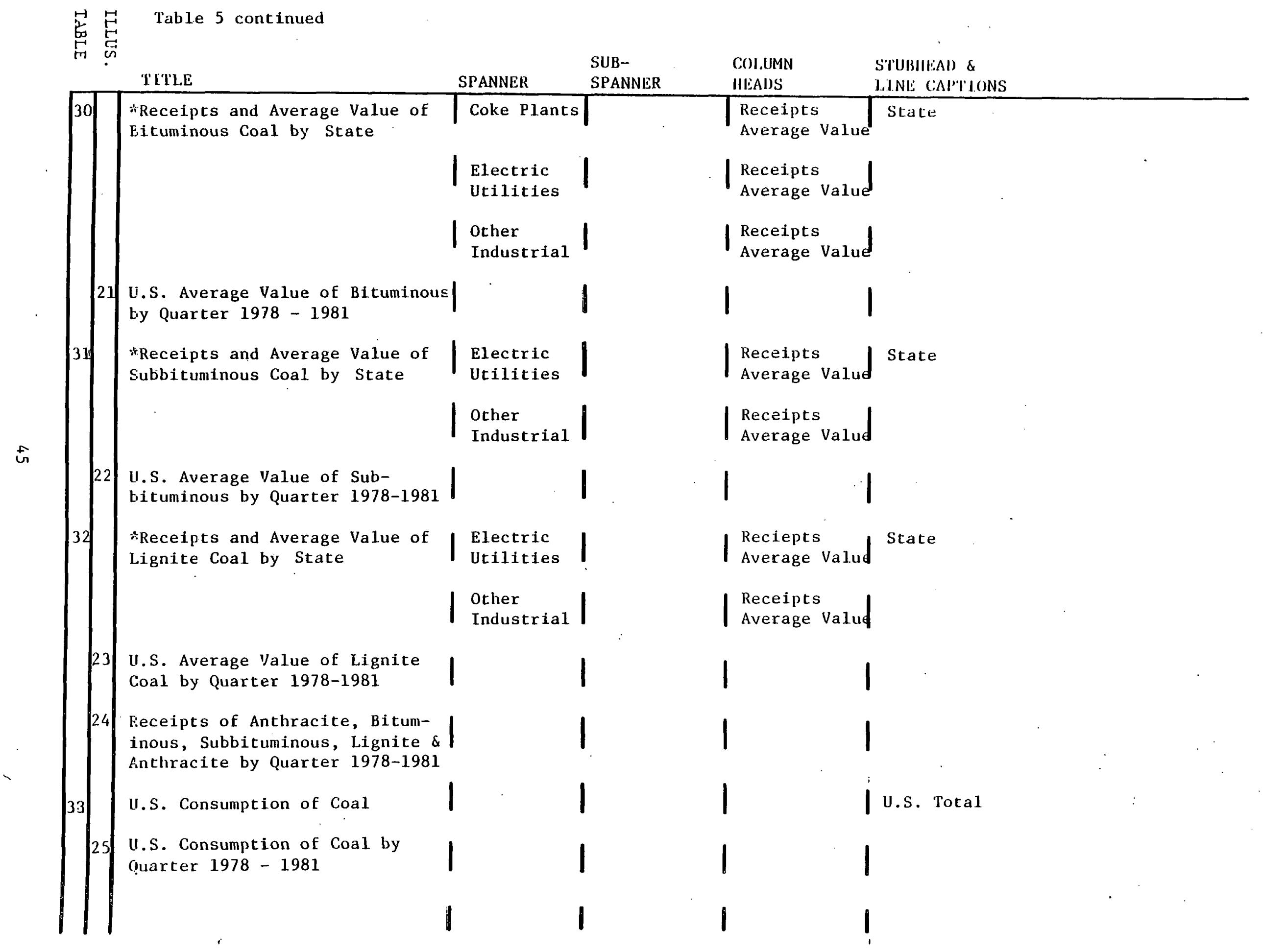




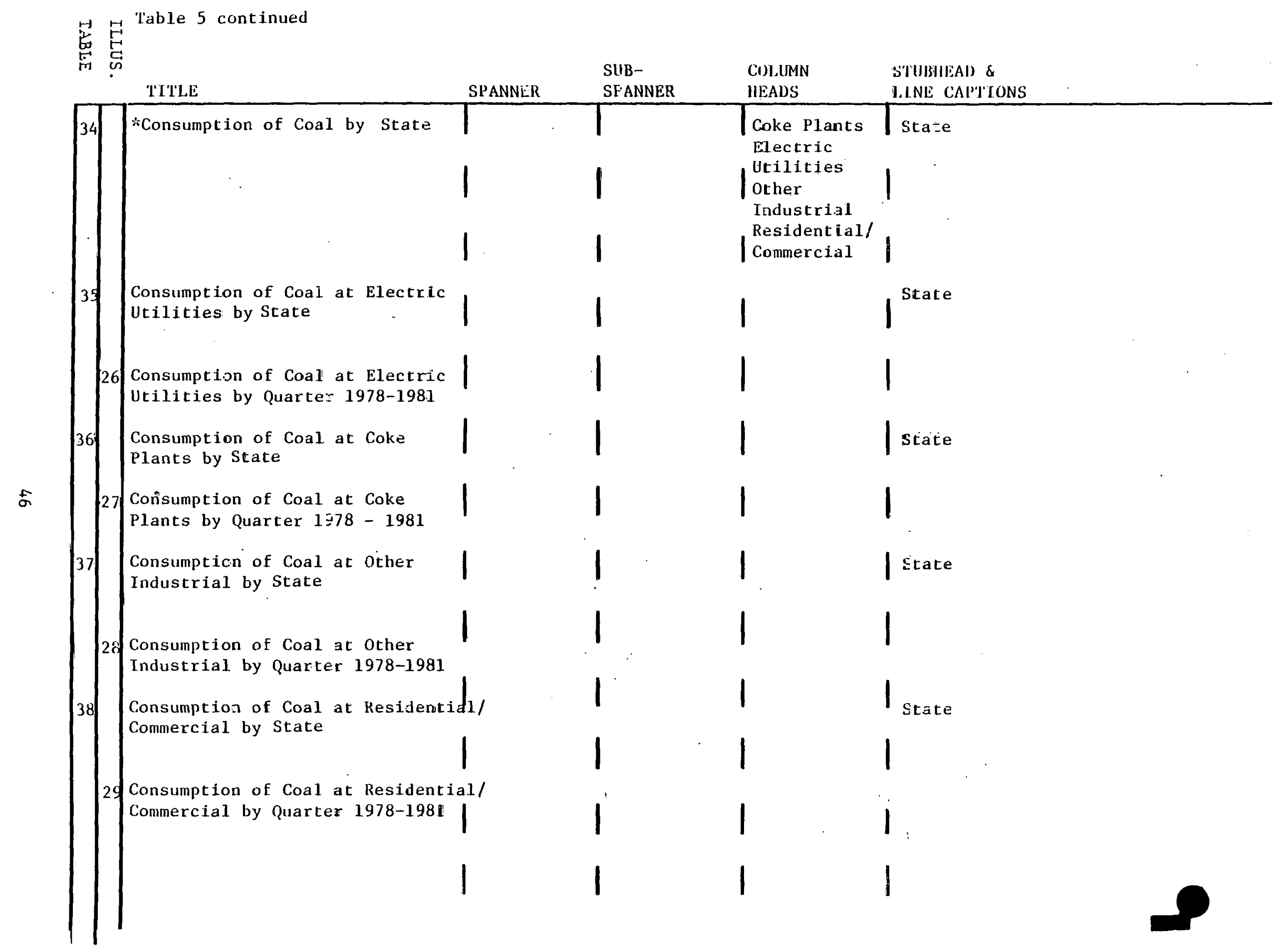




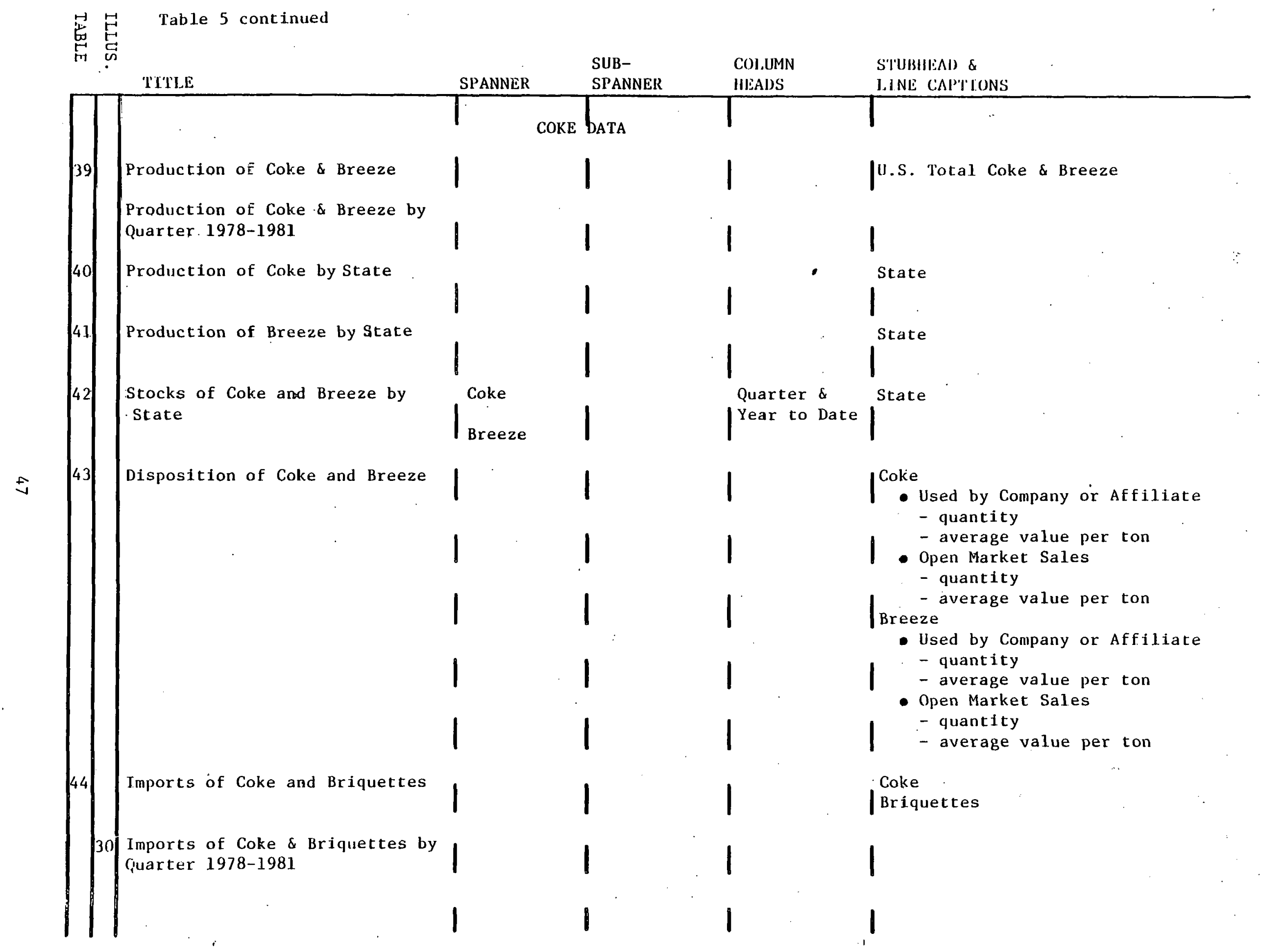




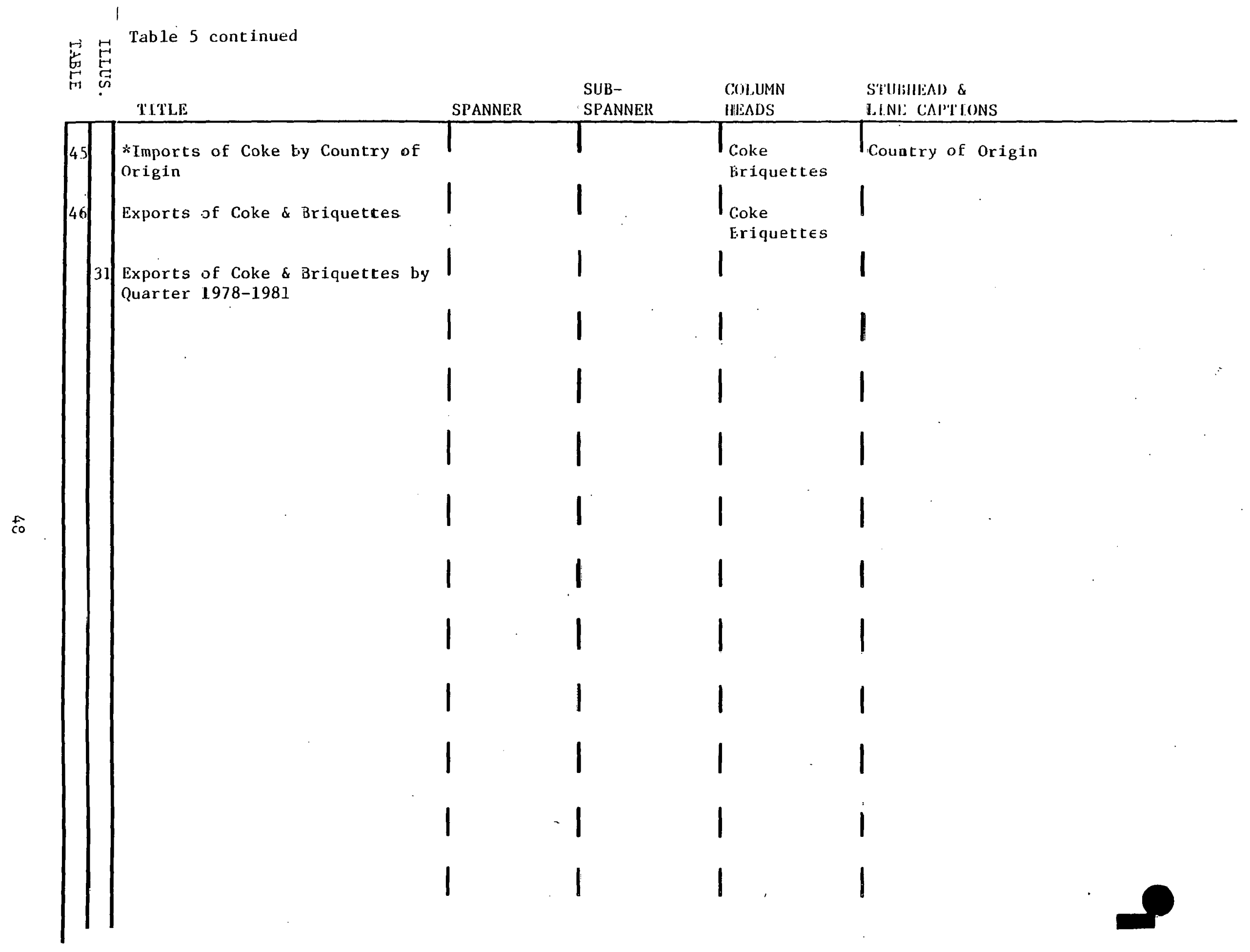




\section{Comparison of Proposed $Q C R$ with Other EIA Publications}

As a summary coal and coke publication, the QCR will contain data for each major function of respective industries. This section of the report consists of a comparison of the data included in similar EIA publications with those proposed for the QCR. This comparison of data content will indicate that the proposed coal/coke publication will include similar information presented in three current EIA publications.

The Coke and Coal Chemicals Monthly

Beginning January 1, 1981, this publication will be published quarterly. It contains data on the production, distribution, stocks, imports and exports of coke, coal chemicals and pig iron production. All data are taken from the EIA-5 with the exception of imports and exports data and pig iron production data which are collected by the Bureau of Census and the American Iron and Steel Institute respectively.

The Coal Distribution Quarterly

This publication has a 120-day time lag. from the end of the reporting quarter to the publishing date. In addition to distribution data (geographic origin and destination and transportation data), the publication also contains quarterly data on production and stocks at mines and distributors.

Bituminous and Subbituminous Coal and Lignite Distribution (annual)

The annual publication includes data for all four quarters and serves as an annual summary. Stocks and production data are omitted from this issue. All data are taken from the EIA-6, with the exception of historical data (19751977) used in the summary, which was collected on the BOM-6-1401A by the Bureau of Mines. 
In addition to these monthly and quarterly publications, EIA publishes a Coal Production Annual and a Coke and Coal Chemicals Annual. Although these Annuals contain more specific data than those recommended for the $\underline{Q C R}$, they could be published within annual supplements. These annual publications are:

The Coke and Coal Chemicals Annual

The Coke and Coal Chemicals Annual has a 270-day time lag between the end of reporting period and publication. The publication has data on coke and breeze production and distribution; vnlume, quality and origin of coal used at cuke plants; and coal chemical production and disposition. The publication rnntains both economic and volumetric data. The daca are collected on the EIA-5 (monthly) and EIA-5A (annual) surveys.

Bituminous Coal and Lignite Productions and Mine Operations

An extensive amount of state and producing district distribution data are published on a yearly basis. However, most of the information in this publication pertains to mining methods and other relatively esoteric information collected on the EIA-7A.

There are other important publications which present coal and coke data. However, these publications contain information which will not appear in the proposed QCR and should be retained. The following is a description of these publications and their relationship to the proposed QCR.

Monthly Energy Review (MER)

The Monthly Energy Review (MER) contains data on multiple energy sources unlike the proposed QCR which will present only coal and coke information. The MER publishes monthly and yearly data on U.S. coal production, coal stocks, and coal consumption by consumer catcgory. The information which is reported has a time lag of 60 to 100 days. 
The coal section of the MER encompasses five coal industry functions. Each function has a different source for data and will be discussed separately.

Production. Production data within the MER have a 90-day time lag. The source for these data is the Weekly Coal Production Report. Revisions are made quarterly and are based on data from the quarterly EIA-6 augmented by reports from state agencies.

Consumption. Consumption data are disaggregated into four subcategories:

- Electric Utilities - Electric utility consumption data has a 4050-day time lag. These data are taken from the monthly FPC 4.

- Coke Plants - Coke plant consumption data has a 90-day time lag. These data are taken from the monthly EIA-5. The EIA-5 will become a quarterly survey after January 1,1981 and the lag between the end of the first month of the quarter and the publishing date will probably increase by 90 days.

- Other Industrial Including Transportation - Data are collected on the quarterly EIA-3 and EIA-6 surveys. Because the EIA-3 does not have 100 percent coverage, an algorithm is used to estimate missing dara. A second algorithm is used to convert the reported quarterly data into monthly figures.

- Residential and Commercial - Data have a time lag of 120 days.

Stocks. Stocks data are organized into the same subcategories found under consumption. The data reported under each of these subcategories are taken from the same sources as those previously discussed in the consumption section. The time lag is between 40-50 days for data on electric utilities and coke plants, and 90-120 days for manufacturing and commercial consumers.

Imports/Exports. These data have a 90-day time $\mathrm{lag}$ and are taken from the Department of Commerce monthly reports.

Annual Report to Congress (ARC)

The Annual Report to Congress (ARC) contains annual U.S. total data organized by consumer category. No import/export data are published with the exception of figures on international coal production. Supply and demand information 
on coke is presented in the $\underline{A R C}$, but information on coal chemicals is not included. The ARC contains annual coal and coke data for a 30-year period, as well as data on oil, gas, solar, and other energy sources.

Quarterly Report to Congress (QRC)

A general report on coal figures is available in the Quarterly Report to Congress, however, no data are published on coke and coal chemicals. The emphasis in the $Q \bar{R} \bar{C}$ as in the Annual Report to Congress is on consumer information but there are more data in the $\mathrm{QRC}$ on exports.

Weakly Coal Production Rejull

The Weekly Coal Production Report is published each Friday and covers the previous week ending Saturday. The weekly data within this publication are estimated until revised figures are received. These estimated data are derived from an algorithm based on weekly carloading reports from the American Association of Railroads. These figures are revised when production data from the quarterly EIA-6 are available. EIA-6 data are augmenter hy state agency coal production reports. Import and export figures, published once a month, are taken from the Department of Commerce reports. These import/export f1gures have a time lag of 60 days. The Weekly Coal Pronuction Report is the most timely of EIA coal or coke publications and is the most widely used.

Cost and Quality of Fuel for Electric Utility Plants

As a monthly publication, the Cost and Quality of Fuels for Electric Utility plants contains annual coal information on the cost quality of fossil fuels delivered to electric utility plants in the United States. The publication includes plant-by-plant data which are reported on the FPC Form 423 and are grouped on a state and regional basis to enable the reader to compare prices of similar fuels delivered to other plants in the same stace and region. 
Electric Power Monthly (EPM)

This report presents monthly summaries of electric utility statistics at the national, regional, state, and local levels. With a time lag of approximately 90 days, the EPM details information as it pertains to all fuel sources. The specific coal data which appear include:

- Net Coal Generation

- Consumption by National Electric Reliability Council Area

- Stocks

- Deliveries by National Electric Reliability Council Area

- Deliveries by Coal Type

- Total Coal Deliveries

- Coal Price Information

Data collected for this report reflect the electric utility industry's commitment to minimize the use of oil and to increase the use of other energy sources, particularly coal.

The attached grids, indicating data contained in the various reports dealing with coal and coke, reveal the relationship between the proposed publication and its ancillary publications. Relative strengths and weaknesses appear, as does the unavailability of sales information. Value data appear in three publications, but their relationship to sales figures is not clear.

Tables 6, 7, and 8 indicate the extent to which the QCR is able to include most of the information in the coal and coke field. With the exception of some data covered in other publications, the QCR offers an inclusive collection of information. 
Table 6. Comparison of Data Elements in Selected EIA Publications

PERIODICITY OF DATA

- Yearly

- Monthly

- Quarterly

- Weekiy

- Year to Date

GEOGRAPHIC DIVISION

- State

- Distrirt

- Area

- Census, Region

- Continerieal Graup

- Loading Point

- Country

- Point of Entry

CONSUMER CATEGORY

- Electric Utilities

- Coke Plants

- Residential/Commercial

- Other Industrial

- Blast Furnace Piants

- Foundries

- Steam Planes

- Agglnmerating Plants

- Auñol Potees

MISCELLANEOUS

- Sales

- Valuc

- Transforers

- Transportation

- Coal Chemical Materials UNITS OF MEASURE

- Short Tons

- Thousands of Short Tons

- Millions of Short Tons

- Billions of Short Tons

- Gallons

LEGEND :

A-COKE \& COAL CHEMICALS (MONTHLY) B - MONTHLY ENERGY REVIEW

D-REPORT TO CONGRESS (ANNUAL)

* Indicates that this information will be found in the proposed QCR.
E-BITUMINUOUS \& SUBBITUMINUOUS COAL AND LIGNITE DISTRIBUTION (ANNUAI F-REPORT TO CONGRESS (QUARTERLY) G-WEEKLY COAL PRODUCTION

H-COAL DISTRIBUTION (QUARTERLY) 

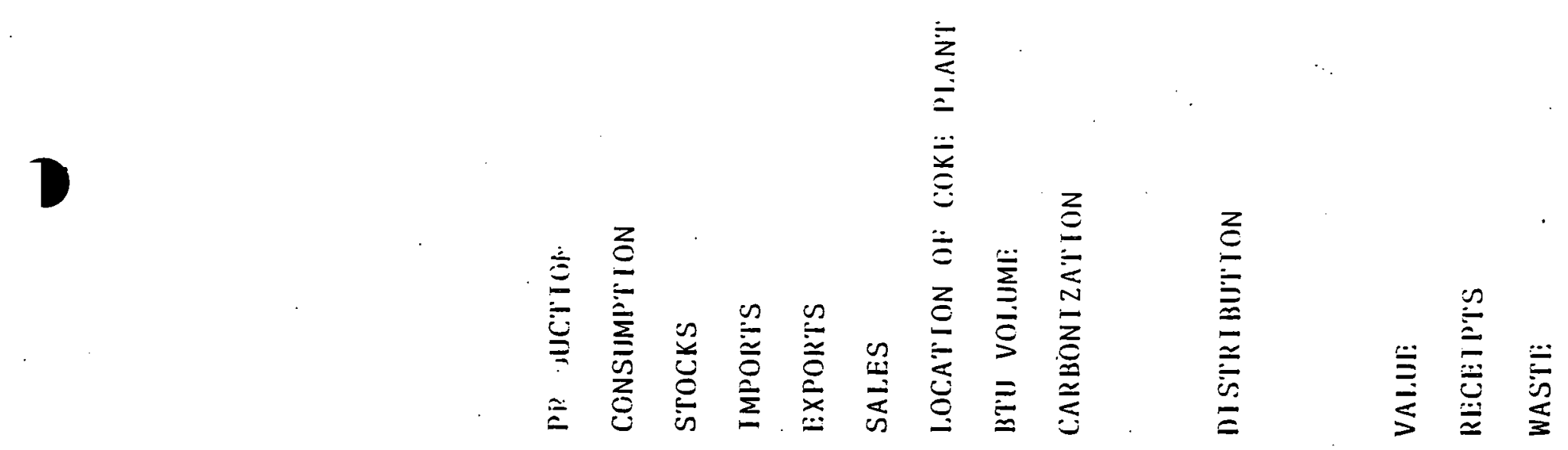

PERIODICITY

- Yearly

GEOGRAPHICAL DIV.

- State

- Country.

- County

CONSUMER CATEGORY

- Agglomerating PI.

- Steam Plants

- Other Industrial

- Blast Furnace

- Foundries

- Furnace plants

- Verchant Plants

\section{YI SCELLANEOUS}

- Coal Chemical Mat.

- Plant Type

UNITS OF YIEASURE

- Galions (1000)

- Short Tons (1000)

- Cubic Feet (Bils)

- Number

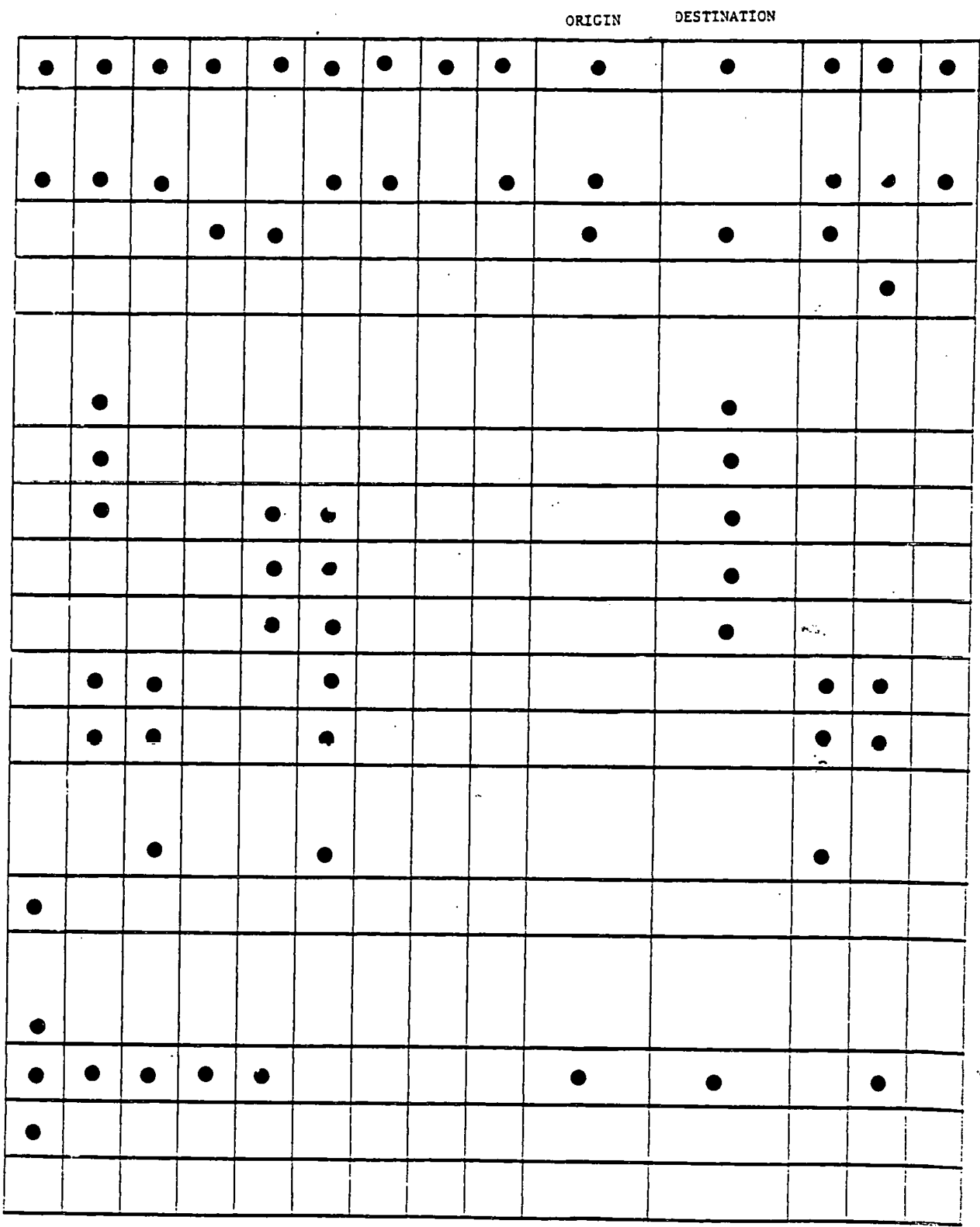

Table 7. Data Elements in Coke and Coal Chermicals Annual 


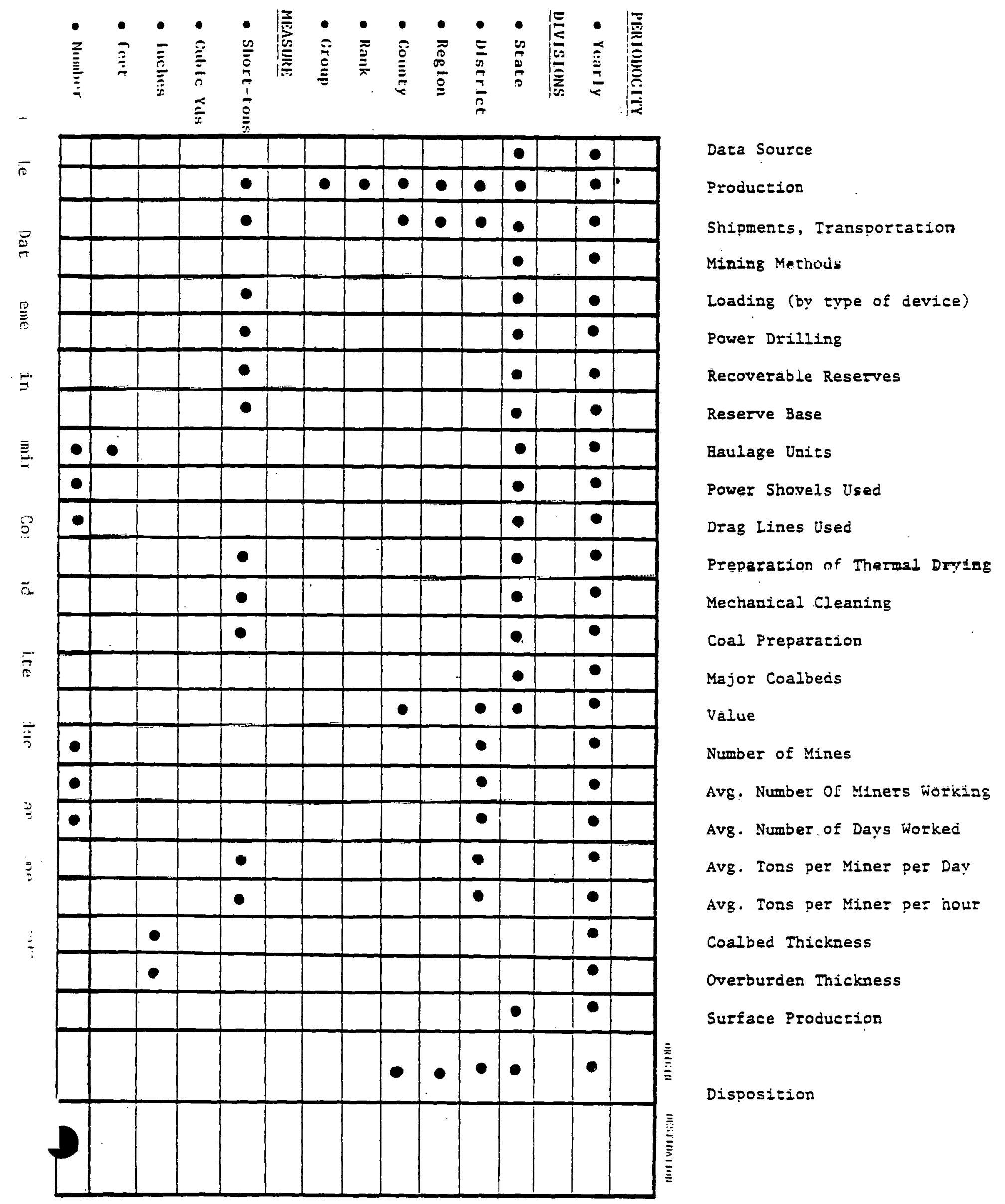




\section{Appendix A}

\section{Abstracts of Coal and Coke Reporting Forms}

This appendix consists of (five) grids that compare elements from eleven data collection forms. These forms are:

- EIA-6 Coal Distribution Report

- FPC Form 4 Monthly Power Plant Report

- FPC Form 423 Monthly Report of Cost and Quality of Fuels for Electric Power Plants

- MSHA 7000-2 - Quarterly Mine Employment and Coal Production Report

- EIA-7A Bituminous Coal and Lignite Production Annual

- EIA-5 Coke Plant Report - Annual Supplement

- EIA-3 Quarterly Coal Consumption Report - Manufacturing Plants

- OSM - 837-1 Coal Production and Reclamation Fee Report

- IRS 720 Quarterly Federal Excise Tax Return

- EIA-26 Western Coal Development Report 


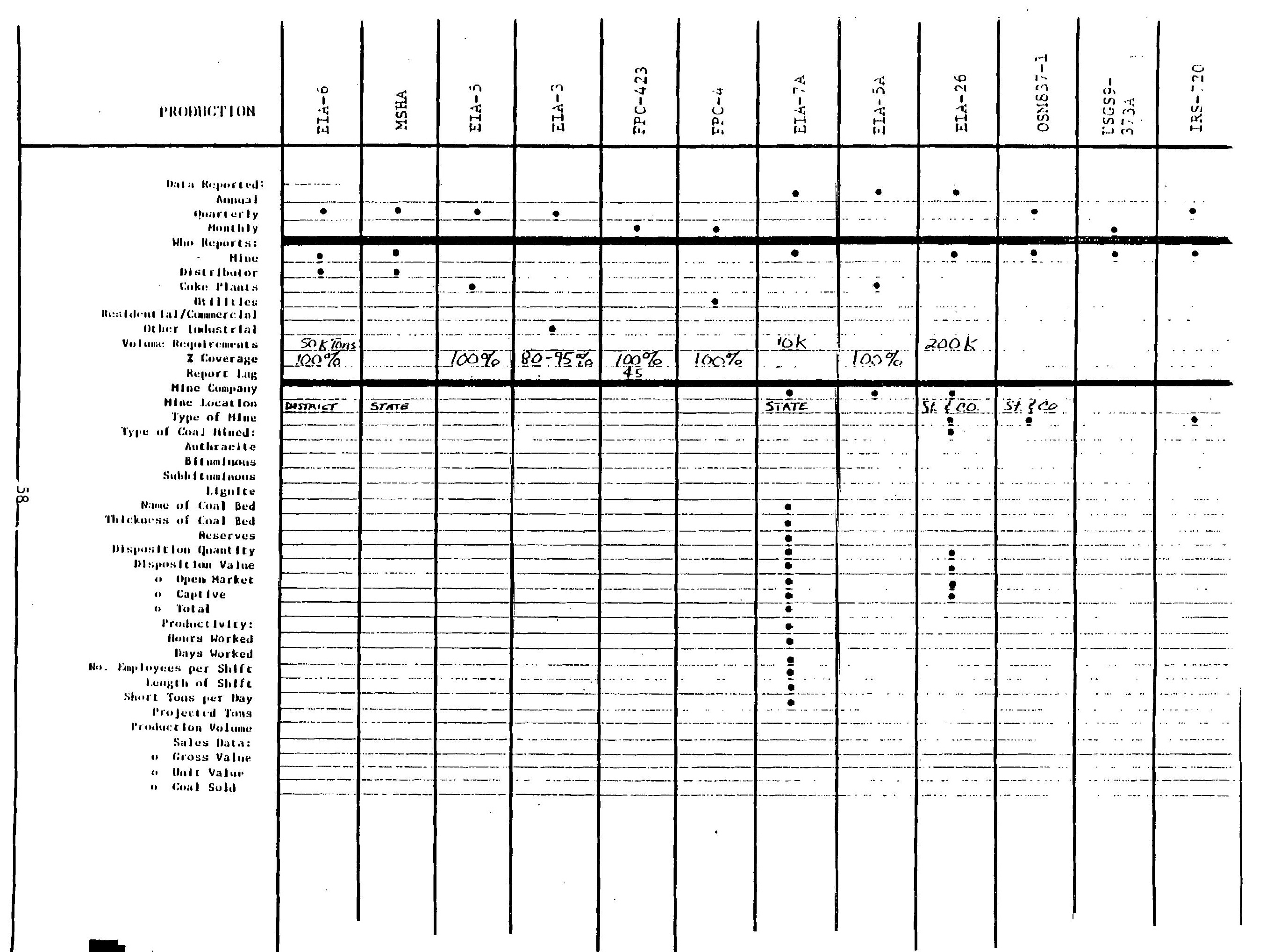




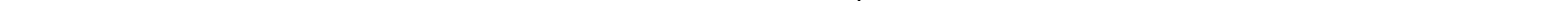




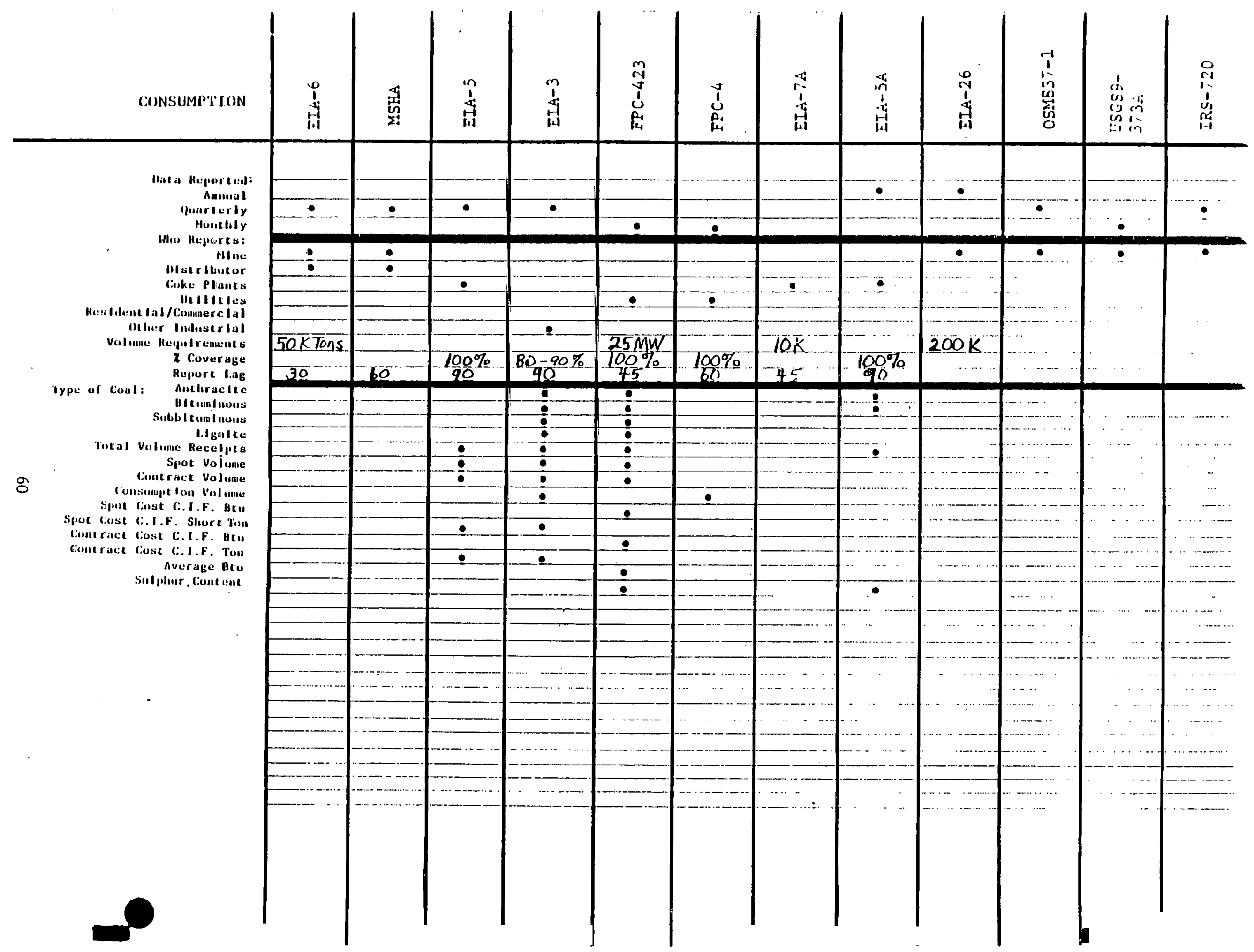




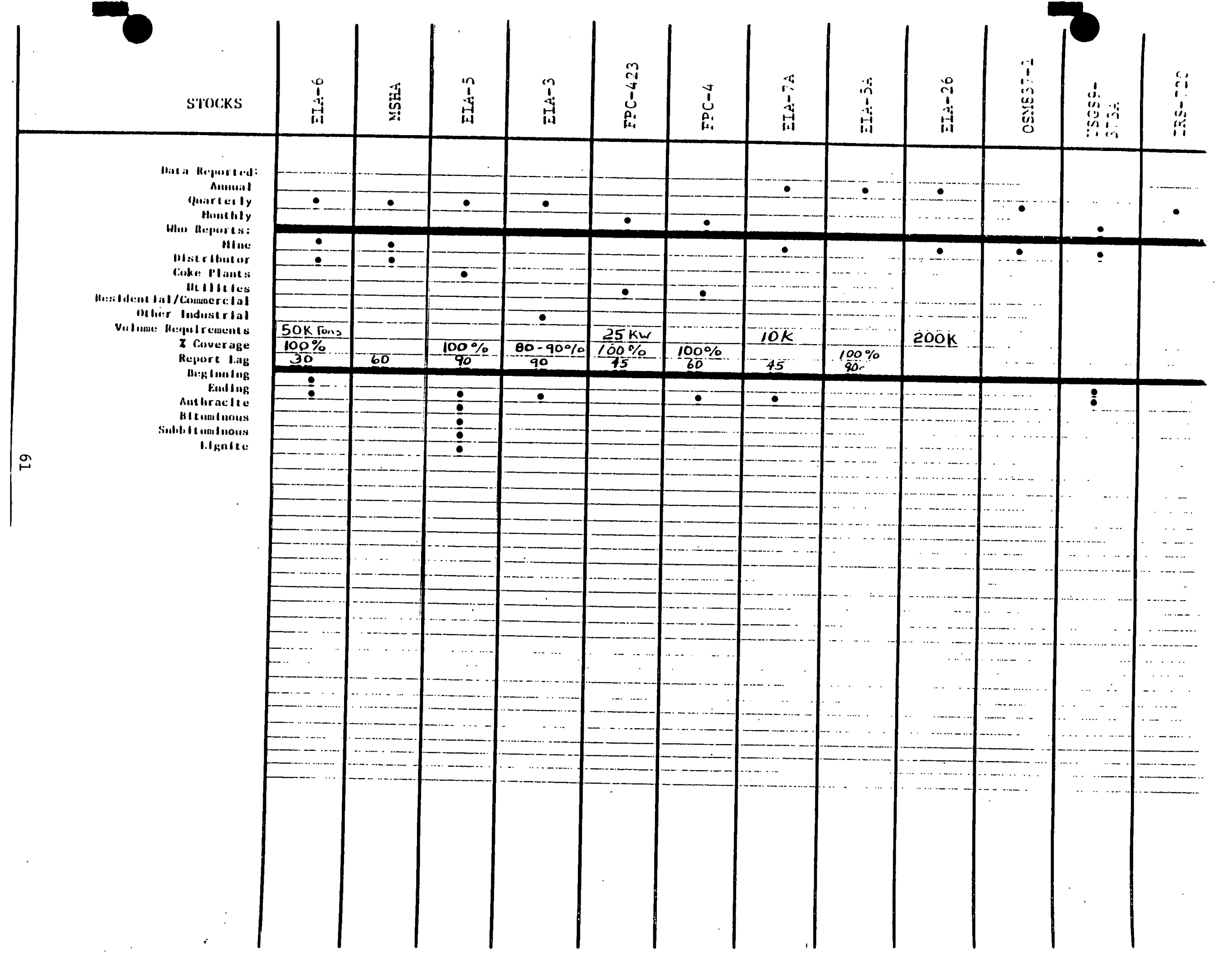




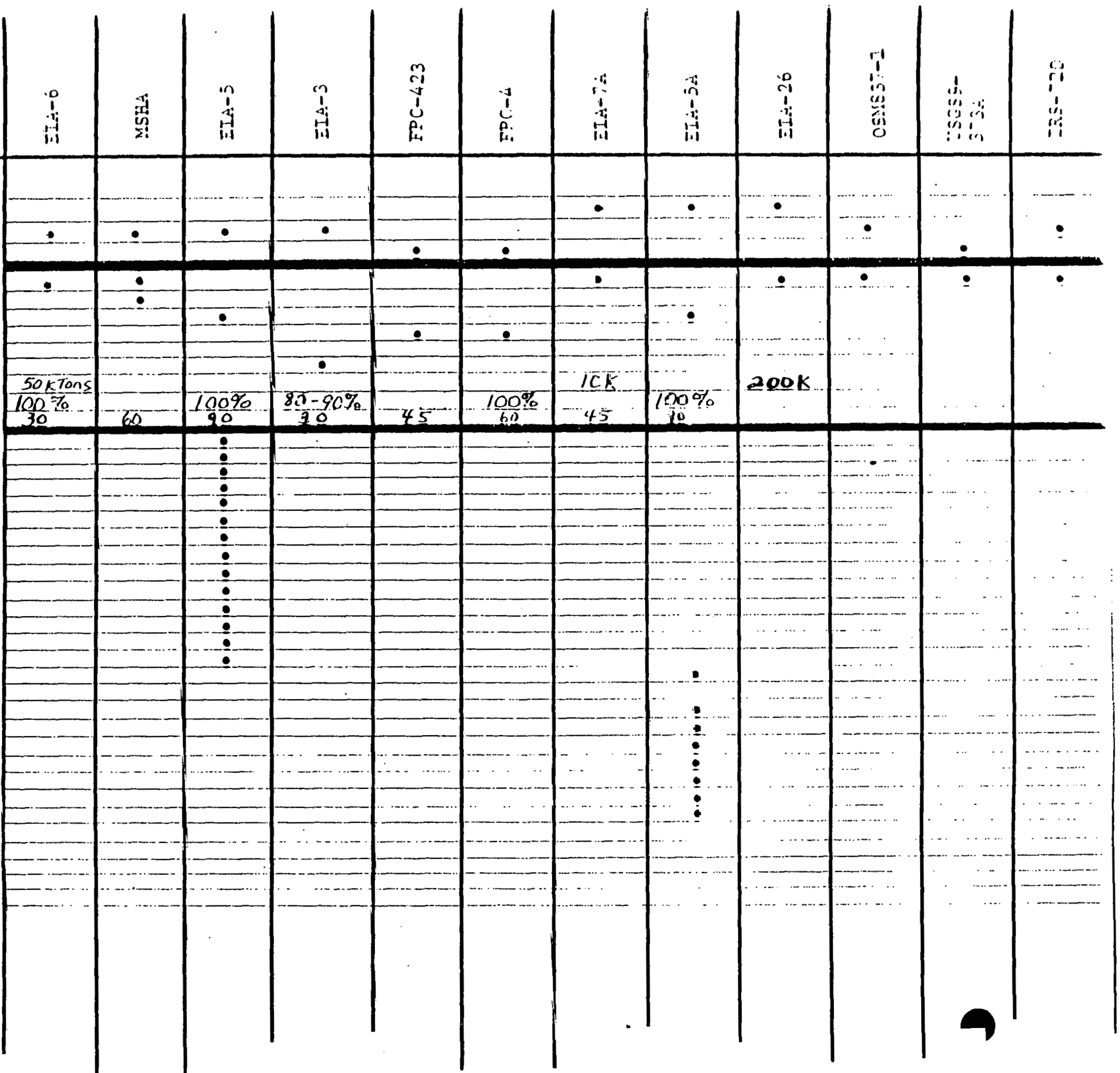




\section{Appendix B}

\section{Coal and Coke Data Reporting Forms}

This appendix consists of the following forms:

- EIA-6 Coal Distribution Report

- FPC Form 4 Monthly Power Plant Report

- FPC Form 423 Monthly Report of Cost and Quality of Fuels for Electric Power Plants

- MSHA 7000-2 - Quarterly Mine Employment and Coal Production Report

- ElA-7A Bituminous Coal and Lignite Production Annual

- EIA-5 Coke Plant Report - Quarterly

- EIA-5A Coke Plant Report - Annual Supplement

- EIA-3 Quarterly Coal Consumption Report - Manufacturing Plants

- OSM - 837-1 Coal Production and Reclamation Fee Report

- IRS 720 Quarterly Federal Excise Tax Return

- EIA-26 Western Coal Development Report 
: the uave namp anri address label is incorrect, please make changes in the space provided at the right.

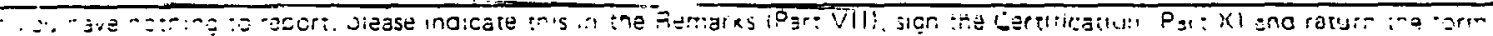

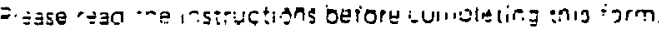

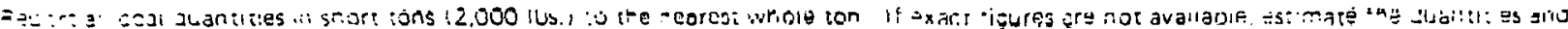

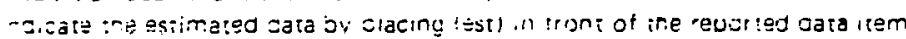

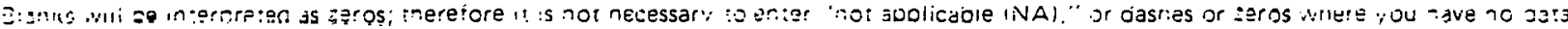

$\therefore$ :320r:

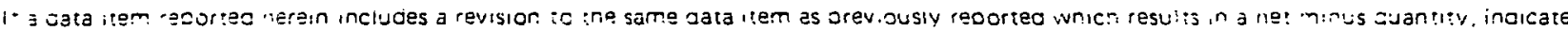

:-is zy znc!osing :-e reoorted quanticy in oarentreses (1)

After anterina your data, please check its consistency using the equations given in Part VI to ensure that your data submission can be processed. If you desire a copy of the publication," Coal Distribution", Quarreriy, please check here.

A. Coal Producing District

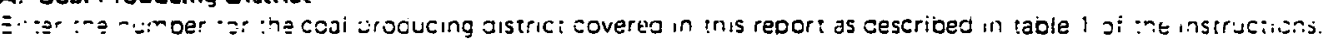

A SEPARATE FORM EIA.6 MUST BE SUBMITTED FOR EACH COAL PRODUCING DISTRICT IN WHISH COAL WAS MINED.

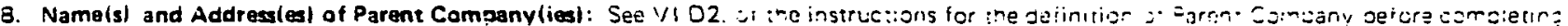
- s sec:i zn. It adait!onji soace is neeged. use a sebarate sheet of f.aver.)

\begin{tabular}{|c|c|c|}
\hline Name of Parent Company & \multicolumn{2}{|l|}{ Address (Street, Citv, State, Zip) } \\
\hline \multicolumn{3}{|l|}{ 11. MINE ORIGIN OF COAL } \\
\hline \multicolumn{3}{|c|}{ 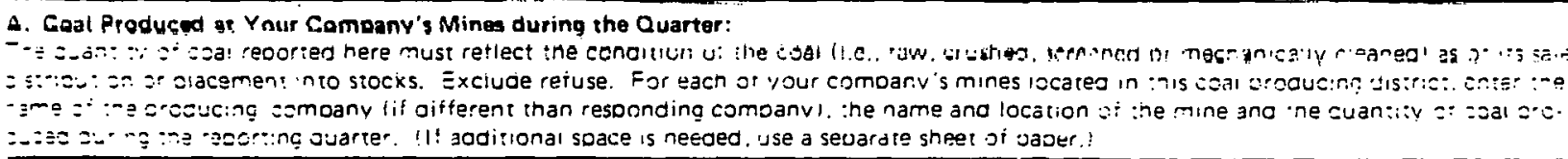 } \\
\hline \multirow[t]{2}{*}{$\begin{array}{ll}\text { Name of Mine } & \begin{array}{l}\text { Name of Producing Company } \\
\text { (if different than } \\
\text { (esponding company) }\end{array} \\
\end{array}$} & $\begin{array}{l}\text { Mine Location } \\
\text { (County) }\end{array}$ & $\begin{array}{l}\text { Quantitv Produced } \\
\text { Ishort tonsi }\end{array}$ \\
\hline & 1 & \\
\hline
\end{tabular}

Total coal oroduced in this District at your comuariy's mines during the quartar ex rfuding refuse.

B. Coal Purchased from Other Companies during the quarer which was produced in this District:

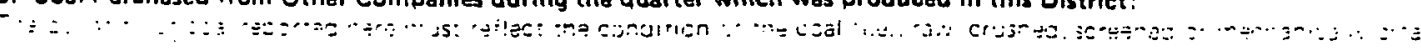

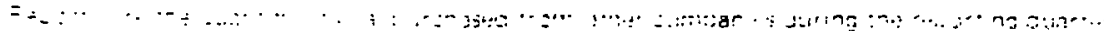

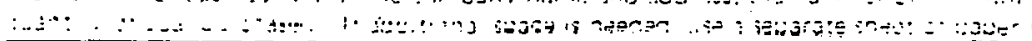

Name of Company $\begin{aligned} & \text { Address } \\ & \text { iStreet. Giv. State. Ziv) Name of Producing Mine(s) }\end{aligned}$

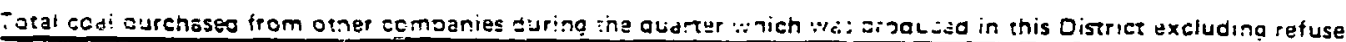


$\therefore=2 \cdot \because-j \vdots \vdots \vdots$

111. DISTRIBUTION WHERE THE CONSUMER IS KNOWN

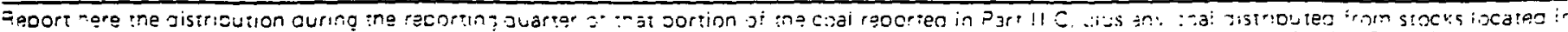

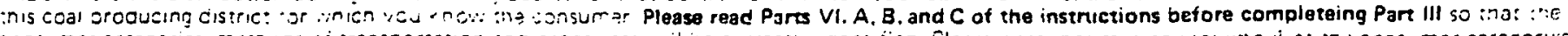

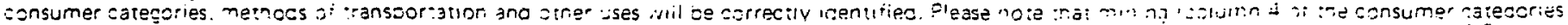

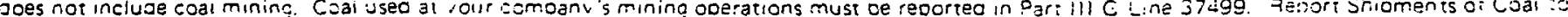
Tiqewarer Piers or Cuastai Por:s ior Overseas Exoorts iexcec: Canada and Mexicol on Line 34802 oi Parilll D

A. Shipments by Rail

\begin{tabular}{|c|c|c|c|c|c|c|}
\hline \multirow[t]{2}{*}{ Destination } & \multicolumn{6}{|c|}{ Quantity Distributed by Consumer Categories (Short Tons) } \\
\hline & $\begin{array}{l}\text { Eectriz } \\
\text { - inuties } \\
\text { (1) }\end{array}$ & $\begin{array}{l}\text { Cxid }=\text { ants } \\
\text { (2) }\end{array}$ & 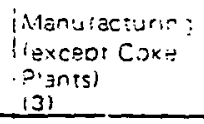 & $\begin{array}{l}\text { iagricuture. } \\
\text { lamining ano } \\
\text { Consiruction } \\
\text { (14) }\end{array}$ & $\begin{array}{l}\text { Resian'is: } \\
\text { Commers.a! } \\
\text { Com } \\
\end{array}$ & $\begin{array}{l}1 T: 3 . \\
161 \\
\end{array}$ \\
\hline $\begin{array}{l}\text { U.S. } \\
\text { Aladama }\end{array}$ & 1 & $\vdots$ & i & (7) & 5 & 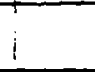 \\
\hline Mlaska & $T$ & $!$ & $i^{\prime}$ & 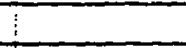 & i & 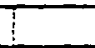 \\
\hline \multicolumn{7}{|l|}{ Arizona } \\
\hline Arkansas & 1 & & 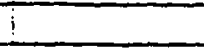 & & T & \\
\hline Caiiiornia & 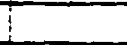 & & 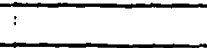 & 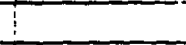 & : & \\
\hline \multicolumn{7}{|l|}{ Co!oraoo } \\
\hline \multicolumn{7}{|l|}{ Connecileut } \\
\hline Selaware & ! & $\vdots$ & & & 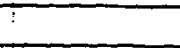 & \\
\hline \multicolumn{7}{|c|}{ Sistric: oi Columola } \\
\hline Fioriaa & ! & & $!$ & & & \\
\hline \multicolumn{7}{|l|}{ Earnia } \\
\hline Igano & & & 1 & & 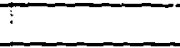 & \\
\hline Ininois & $\vdots$ & & 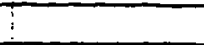 & & $!$ & \\
\hline inciana & & & 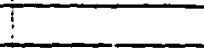 & & 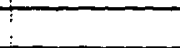 & $i$ \\
\hline \multicolumn{7}{|l|}{ Piva } \\
\hline \multicolumn{7}{|l|}{ Sansas } \\
\hline \multicolumn{7}{|l|}{$\because=n \because j \times x v$} \\
\hline L- :uisiana & : & . & 1 & & $\vdots$ & \\
\hline $\operatorname{lng} 104$ & $:$ & & in & $i$ & - & \\
\hline Wariting & 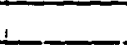 & $\therefore$ & $i$ & & $:$ & \\
\hline Massacr:iset:s & $i$ & 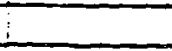 & 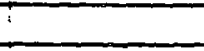 & $i$ & 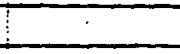 & $\therefore$ \\
\hline wic-liagr & $\vdots$ & 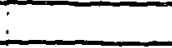 & $\vdots$ & $i$ & $i$ & $\bar{\vdots}$ \\
\hline birn=scia & 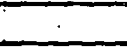 & $\bar{\vdots}$ & 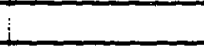 & $i$ & 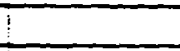 & \\
\hline iniss,ssicel & 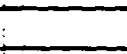 & $!$ & $i$ & & $i$ & \\
\hline Oisscurn & 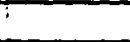 & $i$ & & - & 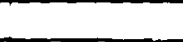 & \\
\hline Der tana & 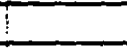 & $T$ & $\div$ & & 7 & 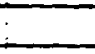 \\
\hline Veoraska & I & & $i$ & & . & 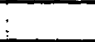 \\
\hline Vevada & 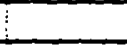 & & $i_{1}$ & $\bar{\vdots}$ & t & i \\
\hline Vewn tamosniro & $\vdots$ & & 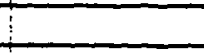 & $!$ & $!$ & $\vdots$ \\
\hline yew Jersev & $!$ & $\vdots$ & 1 & $i$ & $!$ & 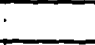 \\
\hline vew Mexics & $T$ & $i$ & & 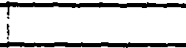 & $T$ & \\
\hline Vew $/ a r k$ & 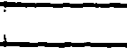 & 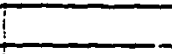 & & 1 & $!$ & \\
\hline Nrir:= Caroling & 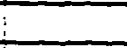 & 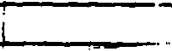 & $I$ & $i$ & $\vdots$ & \\
\hline \multicolumn{7}{|l|}{ Torm Dakota } \\
\hline Sro & · & $!$ & & 1 & & \\
\hline Zs:ancma & & & $!$ & & 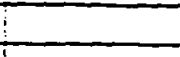 & \\
\hline \multicolumn{7}{|l|}{ 5oman } \\
\hline \multicolumn{7}{|l|}{ Oonnswivanda } \\
\hline \multicolumn{7}{|l|}{$=-x c+1 \sin s$} \\
\hline S.: : Carbinna & & 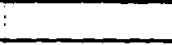 & 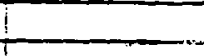 & 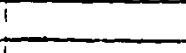 & & \\
\hline Sow:- Dekota & & 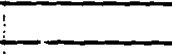 & & 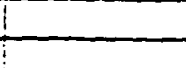 & & \\
\hline Thnessar & & 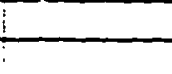 & 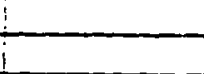 & $\vdots$ & 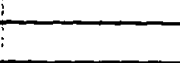 & \\
\hline$\frac{T \sum x a s}{\text { si:an }}$ & & & & & 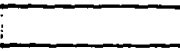 & \\
\hline$\frac{\text { li:an }}{\text { fermani }}$ & & & 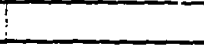 & 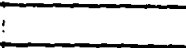 & $\vdots$ & \\
\hline J:m:inia & & 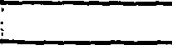 & & $!$ & & \\
\hline$\therefore$ asnngign & & 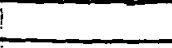 & & & & \\
\hline \multicolumn{6}{|l|}{$\therefore=5::: \div \ln : a$} & \\
\hline \multicolumn{7}{|l|}{ Miscansin } \\
\hline Moritina & & 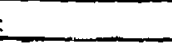 & . & & & - \\
\hline \multicolumn{7}{|l|}{$\sin 323$} \\
\hline \multicolumn{4}{|l|}{$\frac{\text { eves }}{\text { Total rall shipments }}$} & & & \\
\hline
\end{tabular}




\begin{tabular}{|c|c|c|c|c|c|c|}
\hline j.S. (itist by starel & i 181 & (2) & $\begin{array}{l}\text { !? } 3 \text { ?nts! } \\
\text { (3) } \\
\end{array}$ & $\begin{array}{l}\text { Consiruc:ion } \\
\text { (4) } \\
\end{array}$ & : & $(0)$ \\
\hline & $\vdots$ & 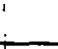 & 1 & $i$ & & $:$ \\
\hline & $i$ & 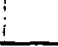 & 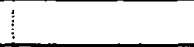 & $\vdots$ & & $\therefore$ \\
\hline & $i$ & 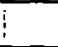 & 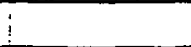 & T. & $!$ & \\
\hline & $!$ & $\vdots$ & 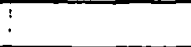 & 1 & 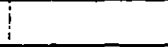 & . \\
\hline & $i$ & & 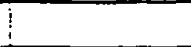 & T! & $!$ & ! \\
\hline & & & & 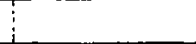 & 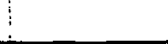 & 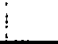 \\
\hline & & & & ! & $\vdots$ & \\
\hline & & & & $i$ & $i$ & . \\
\hline Total shipments via river & 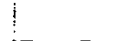 & 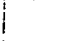 & ! & $i$ & $?$ & ; \\
\hline \multicolumn{3}{|c|}{$\therefore-s=a: a$ now coal was dellvered in ine iver } & \multicolumn{3}{|c|}{ Quantity in short tons delivered by - } & \\
\hline
\end{tabular}

\section{Shipments Via Great Lakes}

Dostination

U.S.

1 :inois

-riạna

Gicrig̣an

Yinnesota

Vew vork

Vortn Dakota

Znio

Sonnsvivania

South Dakota

:Visconsin

Canada

Total shipments via Great Lakes

Indicate how coal was delivered to the Great Lakes.

\begin{tabular}{|l|l|}
\hline & \\
\hline & \\
\hline & \\
\hline & \\
\hline & \\
\hline & \\
\hline & \\
\hline & \\
\hline
\end{tabular}

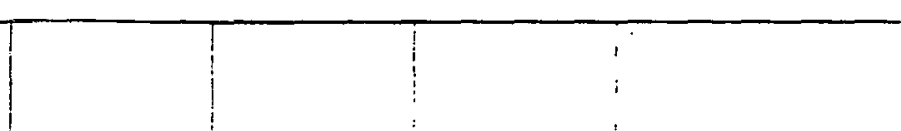

D. Shipments Via Tidewater Piers and Coanal Ports

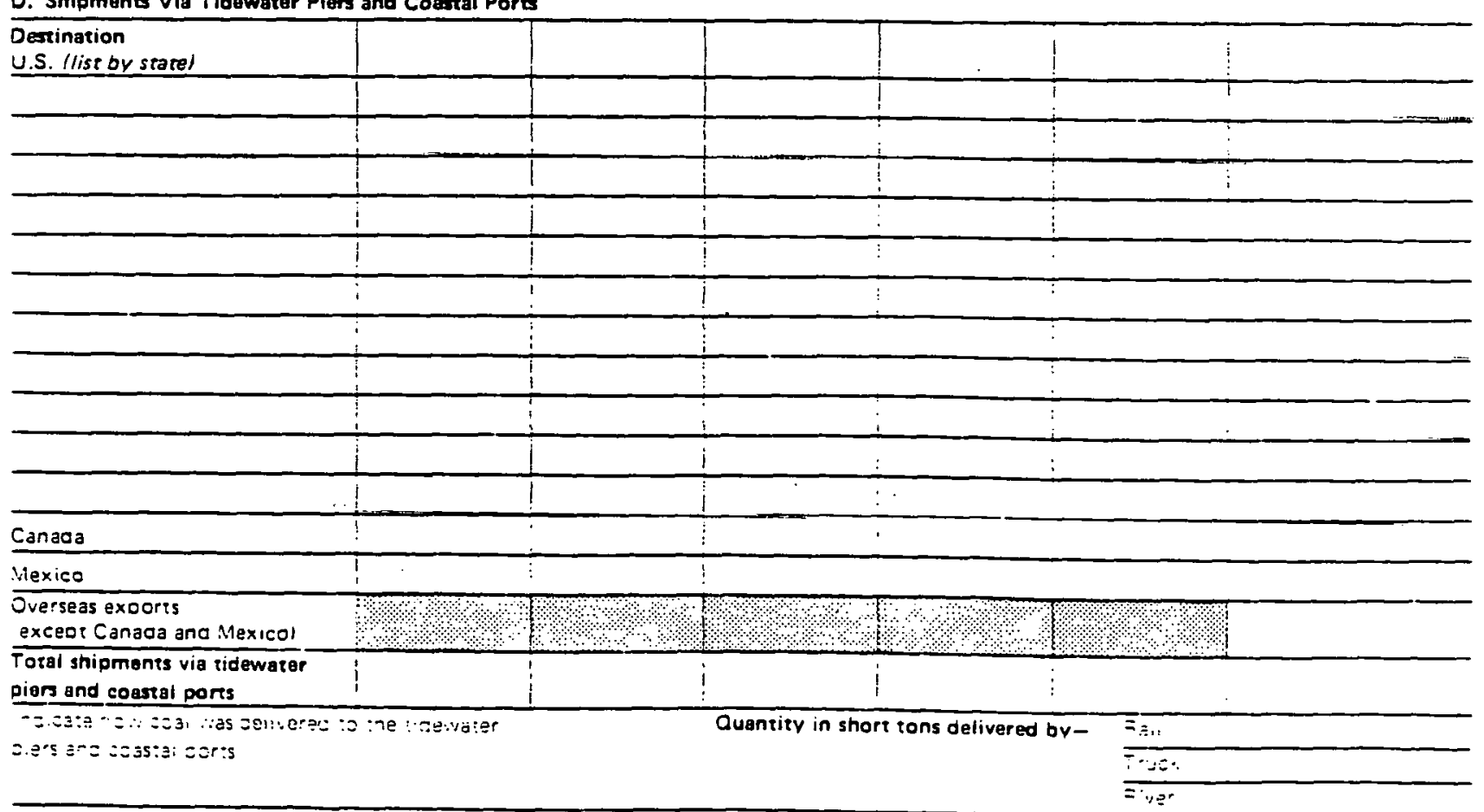

Quantity in short tons delivered by - Rail

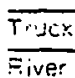




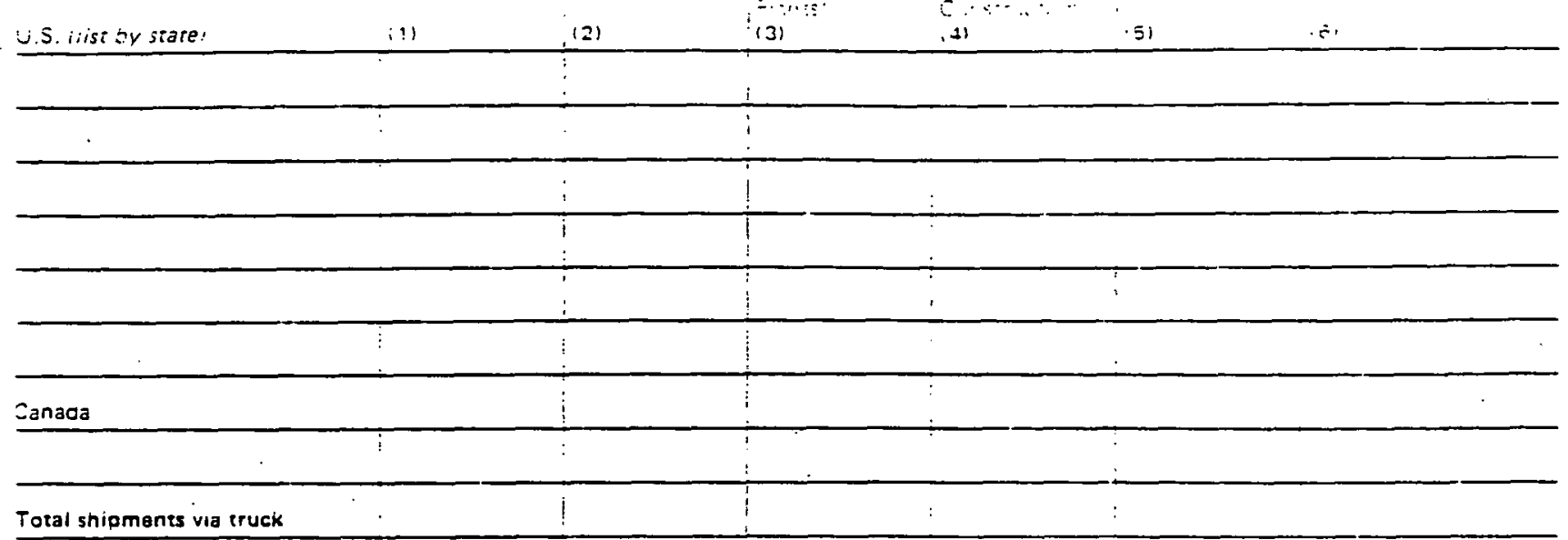

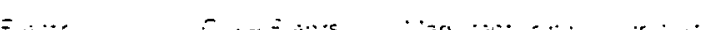

\section{$\equiv: \cdots$ \\ E.... $=4$}

Total shipments via truck

F. Shipments Via Tramwav/Conveyor or Slurry Pipeline (list by stare of destinatior)

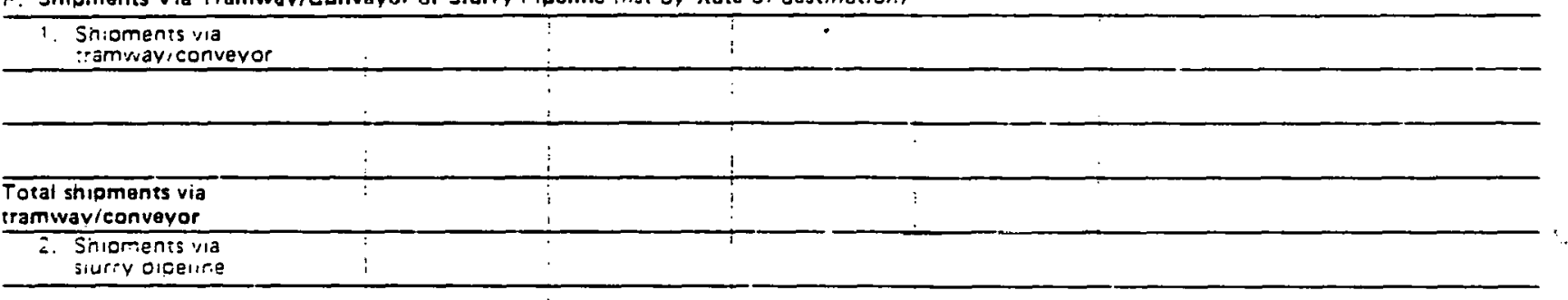

(20)

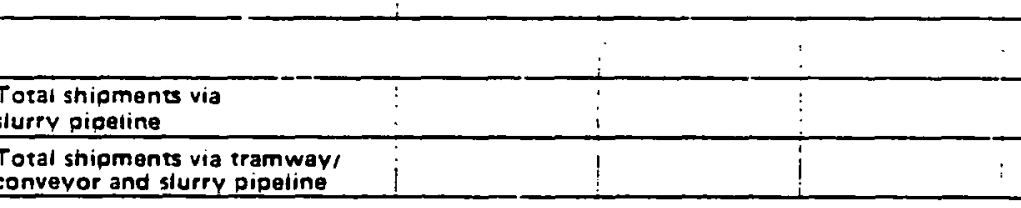

G. Other Uses

Totai Quantity Distri. buted Short Tonsi

Pauroad iver

Essei.sinio suel

Dist gasificat:on iliquefacrion

Eaal useo at your comoany's mines

jus sold :0 emolovees

H. Sales of Coal to Other Snal Distribution Companles where you know and reported the consumer

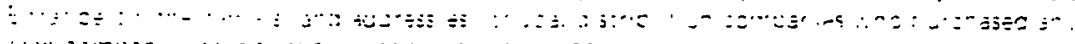

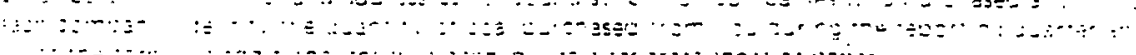

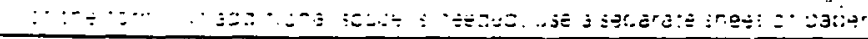

Empany that Purchased Your Coal
$\vdots \cdots=$


Toxal quantity of your coal purchased by other coal distribution comoanies where the consumer is unknown.

$\therefore$ Sol proouced in this oistric: which was heid in stocks oy you comoany at the start of the redorting quarter lexclucie retusel.

E. Soal produced in this district which was held in stocks by vour

'11. JATA CONSISTENCY CHECKS

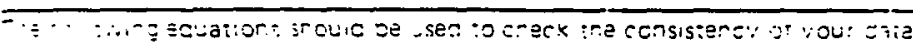

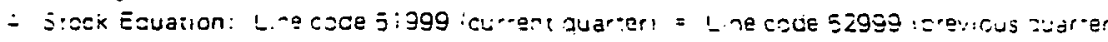

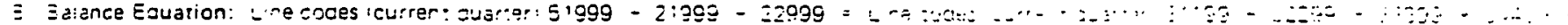

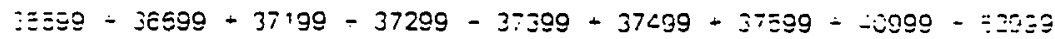

: :- zse equations are not satısfied it means that your data are inconsistent and some data elements are missıng t:om your recort !such as stocksi o; entereo "corractiy. These equations must be satisified bofore your data can be processed by EIA.

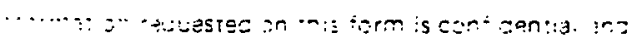

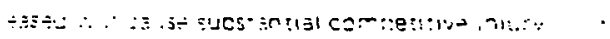

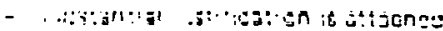

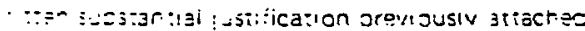

\section{EERTIFICATION}

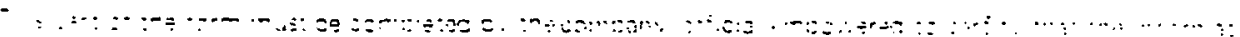

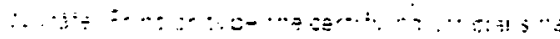

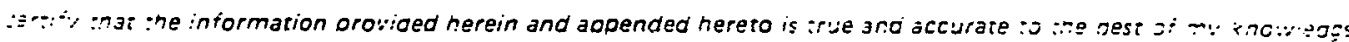

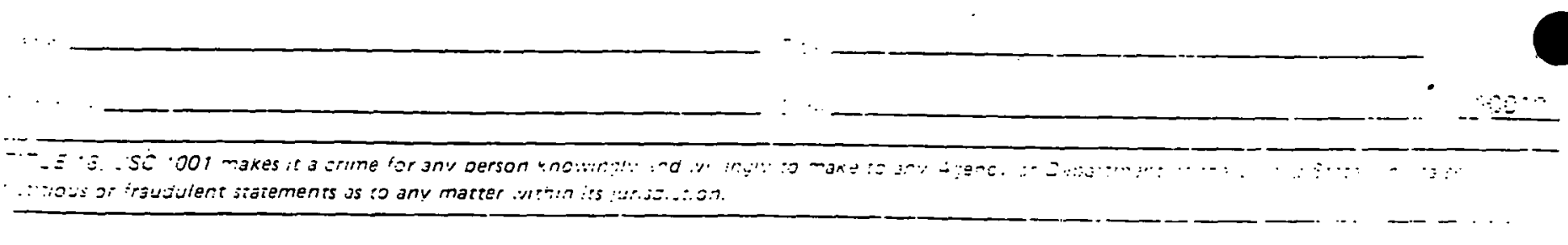




\section{Purpose}

= orm झIA.0 is desıgneo to orovide volume cata for coal distribution by mode of transoortation and consumer category. The data collecteo

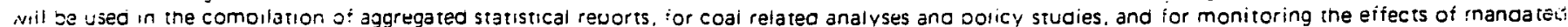
sol orograms. This iorm is a mandatory reporting requirement under the Federal Energy Administration (FEA) AC; of 1974 (P. L. $93-275$ i ano the Powerciant and inqustriat F.jei 'se $\Delta$ ct of 1978 IP. L. 95.6201

\section{Who Shall Submit}

All comoanies in the 50 States and the District of Columbia that owned or purcinased and distributed in excess of 50.000 tons of 5 sal ourıng the year zefined by the current reporting quarter and the previous inree reporting quarters. These comcantes include coal mining comnanies. wholesale coal déalers lincluding orokersl. and retail coal dealers Companies that take custooy (ohysical possession) of the coal and transport but never own or purchase the coal or companies that only negotiate the sales of coal but never own or purcnase the coal need not report. Retain ine coov marked "File Cony" for vour recoros.

III. Where to Submit

Somvanies shall return comolered $\equiv \mid A .6$ forms :0.

Energy Information Administration, El-34

Mail Station: 8G-086. FORSTL

U.S. Department of Energy

Wasnington, D.C. 20585

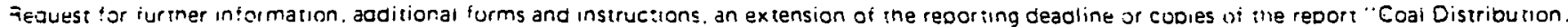
Duarterlv" mav be directed to the address above or by teleonone to (202) 252.6886

IV. When to Submit

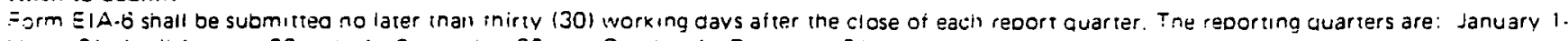
Marcn 31. Aorit 1. June 30. Juiv 1. Seprember 30. ano Ocrober 1 . December 31

\section{Sanctions}

The timely submission of Form EIA.6 bV a comoanv required to report is a mandatorv requirement. Late filing. fallure to file. Jr fallure otherwise !o

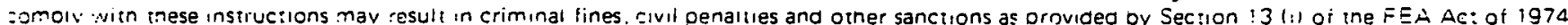
.?. $93 \cdot 2751$.

\section{V1. Definitions}

\section{A. Consumer Categories}

1. Electric Utilities - All privatey owned companies and all publicly owned agencies engageo in the oroduction of electrir oower for public use. Publicly owned agencies include the following: Municipal electric utilities: Federal oower projects. such as the Tennessee Vallev Authority (TVA): and rural electrification, cooperatives, oower districts, and State power projects.

2. Coke Plants - All plants where coal is carbonized for the inanufacture of coke in slot or beenive ovens. Reoort only coal that is carbonized to produce coke. Shipments of coal to coke plants for use in suace heatıng or electric power generation should be included with "Manu facturing lexceot Coke Plantsl." Do not reoort coal used to produce form coke. Include ccal used tor torm coke with "Manufacturing lexcept Coke Plants)."

3. Manufacturing (except Coke Plants) - Those industrial users/olants, not including coke plants, that are engaged in the mechanical or cneinical :ransiormation of materials or substances into new (i.e.. tinished or semifinished) products.

4. Agriculture, Mining, and Construction - Companıes engaged in agriculture, minıng loiher inan cual inı(ıngl, ur consiruction ingustries.

5. Residential/Commercial- Housing units: wholesale and retail businesses (exced coal wholesale dealers): health institutions (hosoitals): social and educational institutions (schools and universities); and Federal. State, and local governments (military installations. orisons, office buldings. etc.1. Exciude snioments to Fegeral Dower prolects. such as TVA; rural electrification cooperatives, Dower districts. and State power orojects: these are to be included in consurner caregory 1 (Electric Utilities).

8. Methods of Transportation to Consumers

1. Rail-Shoments of coal moved to consumers by rail lorivate or uublic/commerciall. Included is coal hauled to or away from a railroad siding by Iruck

2. River - Shioments of coal moved in eonsumers vie river by varge. Fot included are shioments to Grear Lakes Coal Loading Doexs or Tidewater Piers or Cuastal Ports.

3. Great Lakes- Shioments of cual moved to consumers via the Great Lakes. These shiomenis are moveo via ine Great Lakes Coal Loading Docks wnich are identıfied by name and location as follows

Sucerior Midwest Energy Terminal. Suderior. Wisconsin

Bessenter \& Lake Erte Coal Storage \& Transfer Facility. Cunneaut. Ohio

$3 \& O$ Railroad Coal Loading Dock, Lorain, Ohio

CaO Railroao Presque isle Docks. Tcledo. Ohio

Laketront Dock \& Railroad Terminal Comoany Coat Loading Dock. Toreco. Onio

V\&W Sandusky Coal Pier No. 3. Sandusky. Ohis

ConRall Coal Transfer Facilities. Ashtabula. Onio

Pall to Water Transfer Coro. Dock. Chicago. Illinois

4 Tidowater Piers and Cuastal Ports-Shipments of coal moved to Tidewater Piers and Coastal Ports iur further snioments :0 consumers via ccastal :vater cr ocean. The Tidewater Piers are identified by name and location as follows

$3 \& O$ Curris Bav Coal Piers. Saltımore. Maryland

C\&O Coal Piers Nos. 11 \& 15 . Newoort News. Virginia

V\&W Lamoerts Poin Coal Piers Nos. $5 \&$ 6. Norfolk Virginia

Llasama S̈tate Docks Bulk Hanating P!ant, Mobile. Alabama

Liaoama State DockssiMcOuftre Terminals. Mobile. Alabama

Canion Coal Pier. Saltımore Harbor on Chesaoeake Bay

Fennich Coal Pier Greenwich Point. Mhilajelühia. Pa. on Delaware River

a $=r$ : Aicimono Pier. Pier 18-Port Aicrmond. Philadelohia, Pa. on Celaware River

Galveston Regicnai Coal Distribution Center. Pelican Island. Gaiveston. Texas

international Marıne TerminassiPladuemines Parish Terminai, Mite 57 AHP-Mississiopi River. Aoorox. $30 \mathrm{miles}$ South of New Orleans

Energy Terminats of Houston. Inc., a Subsidiary of Soros Așoçiates. Hnistan. Texus

The Loastar Ports incluoe t.nose locared at Charteston. S.C.. New York. N. Y.. San Diego. Ca.. Los Anceles. Ca.. Seattle. Wa. 
5. Truck - Shipments of coal moved to consumers by truck. Not included is coal hauled to or away irom a railroad siding by truck.

6. Tramway. Conveyar, or Slurry. Pipeline- Shioments moved to consumers by tramway, convevor. or siurry dideline.

C. Other Uses

1. Railroad fuel- Shioments of coal to railroad companies to be used as fuel lengine. powernouse. etc.)

2. Vessel/Ship tuel- Shioments of coal to be used as vessel/shio fuel.

3. Coal gasification/liquefaction- Conversion of coal to gaseous (low to medium BTU gas) or (iauid (such as synthetic crude oil and metnanol) hydrocarbons.

4. Coal used at your company's mines - Coal consumed at your company's mines in this district during the redortiny quarter

5. Coal sold to employees- coal sold to employees during the reporting auarter.

\section{Miscellaneous}

1. Coal Producing Oistricts - See definitions of Coal Producing Districts in table 1 of the instructions.

2. Parent Company-A company which solely or jointly owns the reporting company and which is not itself a subsidiary of or owned by anotner company.

\section{General Instruetions}

A separate report snall be submitted for each coal producing district in which the ccal was mineo. Complcte all data items on the form apolicaole ts your operation. All figures should be rounded to the nearest whole number. Report all tonnage in short :ons $(2.000$ oounds). Blanks will be interorete as zeroes: therefore it is not necessary to enter "not applicable (NA)" or dashes or zeroes where you have no data to renort.

\section{VIII.Specifie instruation}

How to report the methods of transporting coal to a consumer:

A. If the shioment involved only one method of transportation from the point of origin to ine consumer, report the shioment in ine section sor that metriod of transportation.

8. If the shipment involved more than one method of transoortation from the point of oriqin to the consumer. use the foltowing guisieines in re. porting the method of transportation:

1. If water transportation was involved, regardless of other methods of transportation also involved, reoort the meinod of transportation as one of the three types of water shipments, i.e., river. Great Lakes, or Tidewater Piers and Coastal Ports. In addition, specify now the sinioment(s) wasiwerel delivered to the river (rail or truck), Great Lakes (rail, truck, or river) or Tidewater Piers or Coastal Ports (i.e., by rail. truck or riverl.

2. If rall ano truck are involved and no water transoortation was involved, then report the method of transoortation as rail.

3. Truck is to be reported as the method of transportation to the consumer oniy if the coal was snioped directly to ine consumer by truck.

\section{Disctoaure Information}

The information contained on form ElA.6 mav be (i) information which is exempt from disclosure to the public under the exemotion for trade secrets and confidential commercial information specified in the Freedom of Information Act (FOIA) [5 U.S.C. 552 (b) (4)] or (ii) oronibited from ouolic re. lease oy 18 U.S.C. 1905. However, before a determination can be made that particular information is within the coverage of eitner cf these statutory provisions, the person submitting the information must make a showing satisfactory to the Department concerning its confidential nature.

Therefore, you should state briefly and soecifically lon an element by element basis if possiblel, in a letter accompenying vour submission of ime form. why you consider the information concerned to be a trade secret or other proprietary information. whetner such information is customarily iraatad as conficential by your company and the industry. and the type of competitive harm that would fesult to your comoany from disclosure of the informa. tion. In accordance with the provisions of 10 C.F.R. 1004.11 of DOE's FOlA regulations. DOE will determine whether any iniormation submitted snould be withngld from public disclosure.

If DOE does not receive a request for exemotion from you, it will assume that you do not object to public disslosure nf any intarmation submittea on this form ov your companiv. A new written justification need not be submitted each time a form ElA-6 is submitteo if -

a) your views conceming information items identified by you as orivileged or confidential have not changed and

b) a written justification serting forth your views in this regard was previousiy submitted.

By statutory au thority DOE must provide this information, when requested. to the Congress or any committee of Congress ano the Genera! Accounting Office. 


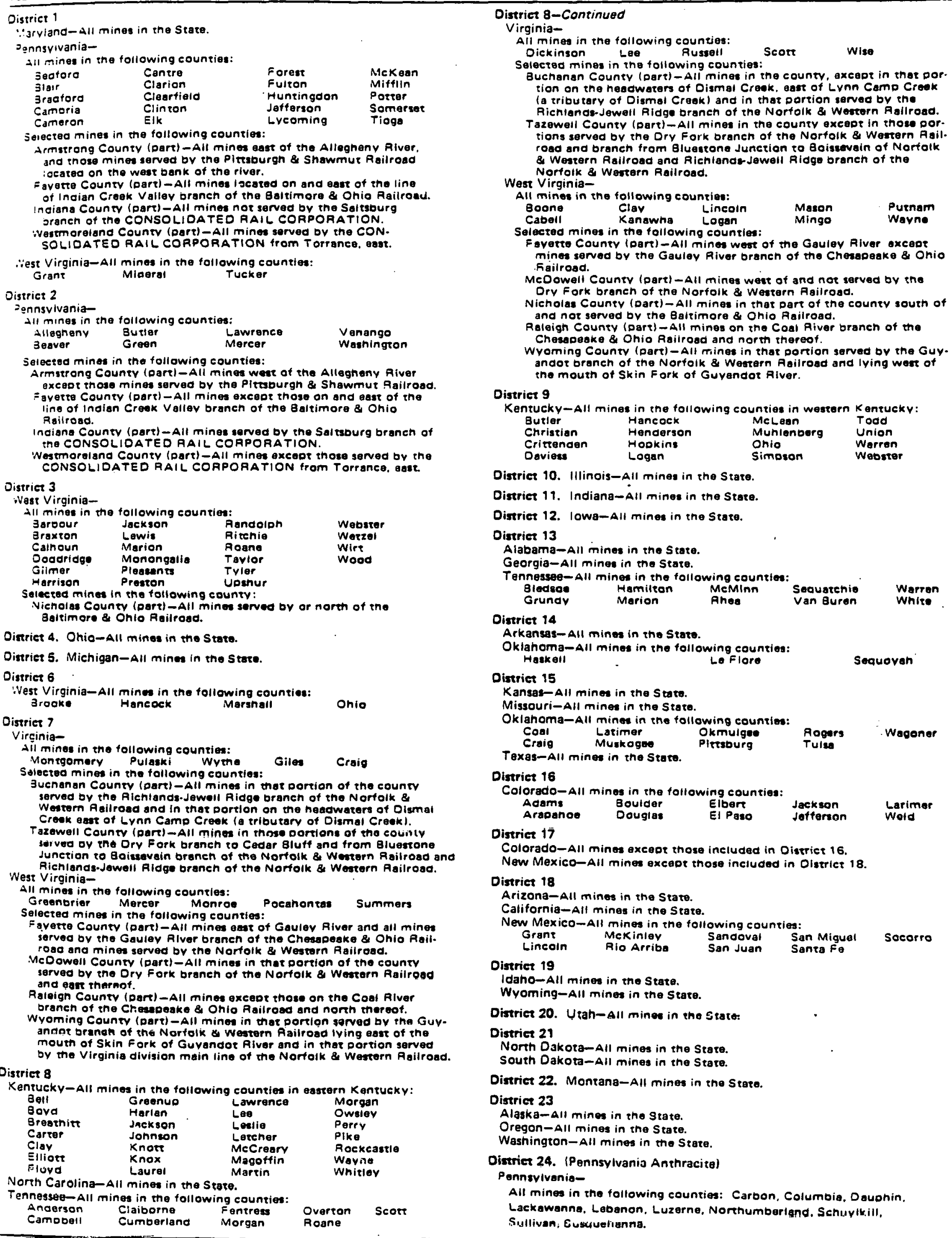




\section{DEPARTMENT OF ENERGY \\ MONTHLY POWEa PLANT REPORT} exclusive of auxwury of nouso

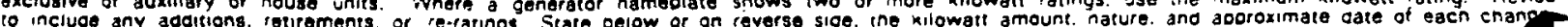

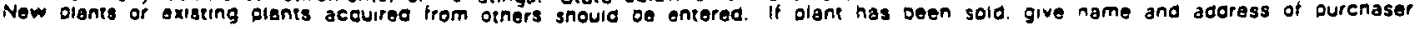

GENERATION - Rocon nat genoration (gross less use oy oower piant for auxitiary equioment) by water sower and by Each Kind of Fuel-anthracite. oituminous or lignite cost. coke. iuei oil. naturat gas. nuetear. or otner (Specily) Gibese give estimates if exact figures are not avaliabie.

FUEL CONSUMEO. Reoor actubl of estimated amount of fuel useo in generating dectric energy inclueing fuei for maintenance of stanaby service. A

WUEL STOCXS. Enter coai and fual orl neld for slectric energy generation including regular stoeks at olant and in cars or barges at olant site. Amounts neld in centrat storage yards snould be incisded mith approoriare note. Reoort io nearest whole unit.

PQIME MOVER TYOE
INC

\begin{tabular}{l}
\hline INSTALLEO CAPACity \\
imaYiuUM NaMEPLATE
\end{tabular}

SIND OF FUE




\section{QUALITY OF FUELS FOR ELECTRIC PLANTS}

\section{GENERAL INSTRUCTIONS}

1. A separate form is to be completed by each electric power producer for each of its electric generating plants (including leased plants) with a total combined steam-electric, combustion turbine and internal combustion ergine powered generating capacity of 25 megawatts or greater during the reporting inonth. Units of fuel to be reported separately for the month are total quantities representing individual laboratory analysis, combination of samples or any other basis used for determining payment to each f'uel supplier for the total receipts for the month.

2. The completed form is due the 45th day after the close of the reference month and is to be sent to the Department of Energy, Energy Information Administration, 1000 Independence Ave., S.W., Mail Code 2914, Room BG-042, Washington, D.C., 26585. (Send six coples Including the originals.)

\section{SPECIFIC INSTRUCTIONS FOR EACH ITEM OR COLUMN ON PAGE ONE OF THE FORM}

Show electric utility company and plant names, location and plant number as shown on FPC Form 67. If a new plant, obtain a plant number from the EIA.

Use a separate line for reporting each delivery of fuel received at the plant during the repcrting month. FSee also instruction for column (7).] Fili in each line coaplete-yi do not use ditto marks.

(0) For each purctase report separately the quantity of fuel that is to be used for (S) stean turbine, (GI) combustion turbine or (IC) internal combustion engine.

(1) Report separately for coal and oil purchases and use only the following codes: (S) for "spct" purchase, (NC) for new or newly renegotiated contract purchases under which deliveries were first made during the rem porting month, (CE) for contract purchases under which the price is changed from the price of the previous delivery under an existing contract due to provisions for automatic price adjustment, or (C) for all other contract purchases.

Fol gao purchases use only the codes (I) for "interruptible", (F) for "firm" हnd (OP) far "off peak".

(2) For contract purchases indicate "Yes" if contract expires within 24 month following the reporting monlh; otherwise indicale "No".

(3) Identify fuels using the following abbreviations for Coal - ANT = anthracite, $B / 1=$ bituminous, SUB = sub-bituminaus, $116=1$ ignitei for $0 i l$ F02, F04, F05, F06, Cru $=$ crude, I0P $=$ lopped crude, KEA $=$ kerbsine, JF :jet Fuel, $L P G=1$ liquef. petroleum gas, $P C=$ petroleum colte, for Gas - NG = natural gas, SNG = syrithetic natural gas, LNG = liquefied natural gas, RG :refinery gas, $B F G=$ blast furnace gas, $\mathrm{COG}=$ coke oven gas; for other fue MIH = methariol, otherwise $x=$ specify in footnote. Include starter fuel.
(4) For coal show (S) for surface mined or (U) for underground mined.

(5) Show state and Bureaw of thines coal producing district.

(6) For coal, show name of mine and county from which coal originated, if avallables for oil, show supplier and refinery or port of entry for gas, show pipeline (supplier) or distributor, producing area by state or port of entry.

(7) Specify quantities in units of a thousand(use thousands of tons for coal, thousands of barrels for oil and other liquid fuels and thousands of Mcf for gas). For exenple, if 213,000 tons of coal is delivered during the reporting month, report 213 . Show separate quantilies for eacii :lass of fuel. To derive the quantity, group all luels for eacil $\therefore i s$ of fuel. To derive the quantity, group all luels
recolved within the month from the supplior for which the price wasbased recelved within the month from the supplier for which the price was based upon a given ur related set of laboratory analysis. For quantities of fuel received from a given supplier during the month for which no laboratory analysis is made, report on the basis of the last previous labor on the basis of contract specifications or estimates, and specify in a footnote the basis used.

(8) List the average BIU content of each fuel in terms of BIU per pound for cual, Blu per gallon for oil (and other liquid products), or BIU per cubic foot for gas.

(9) Show sulfur content of each unit of fuel in lerms of percent sulfur by weight. Show accurate to nearest $0.01 \%$.

(10) Show ash content of each unit of fuel in terms of percent ash by weight. Show accurate to nearest $0.1 \%$.

(11) Specify in cents per million BTU F0B plant. Show accurate to the nearest 0.1 cent. 


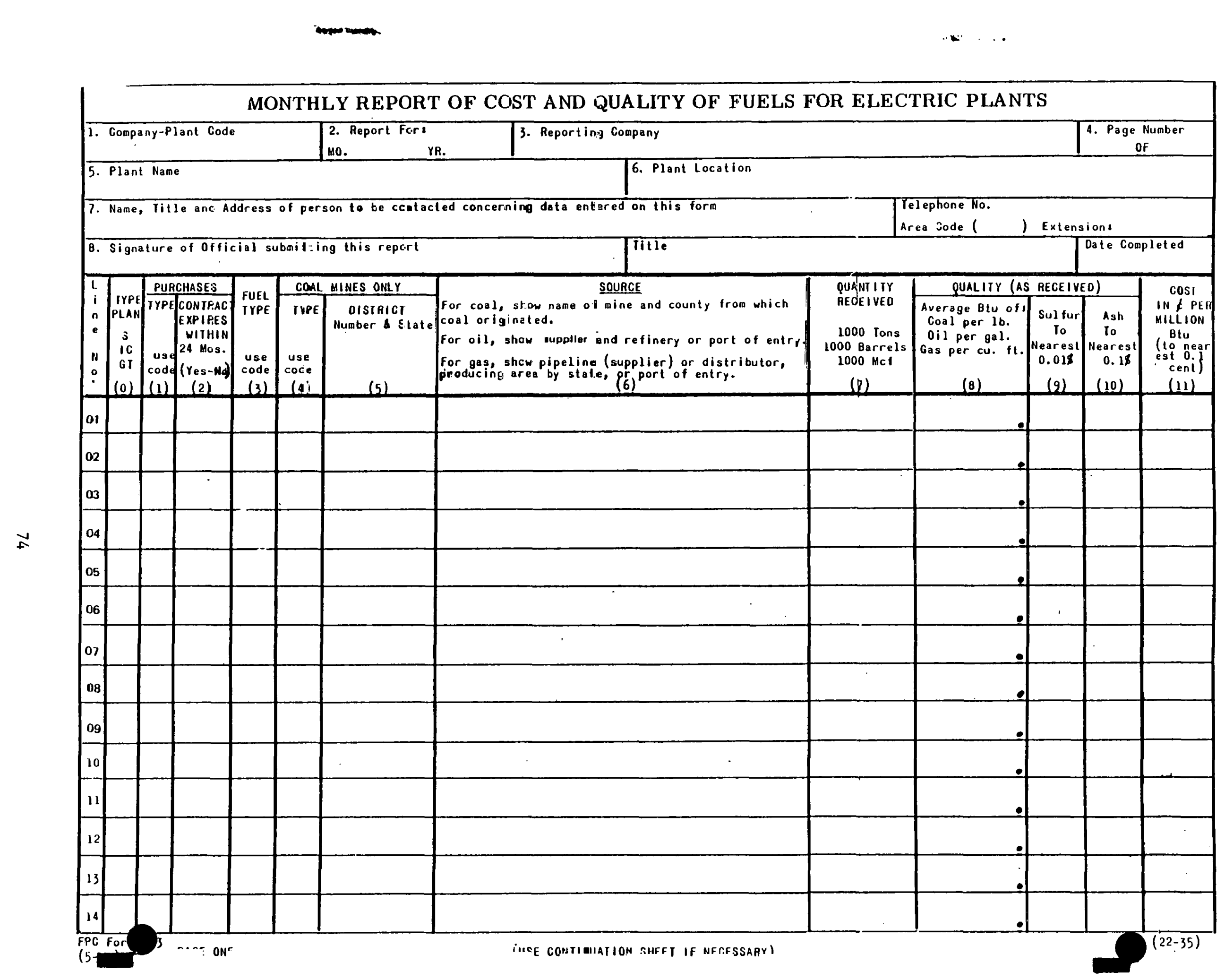




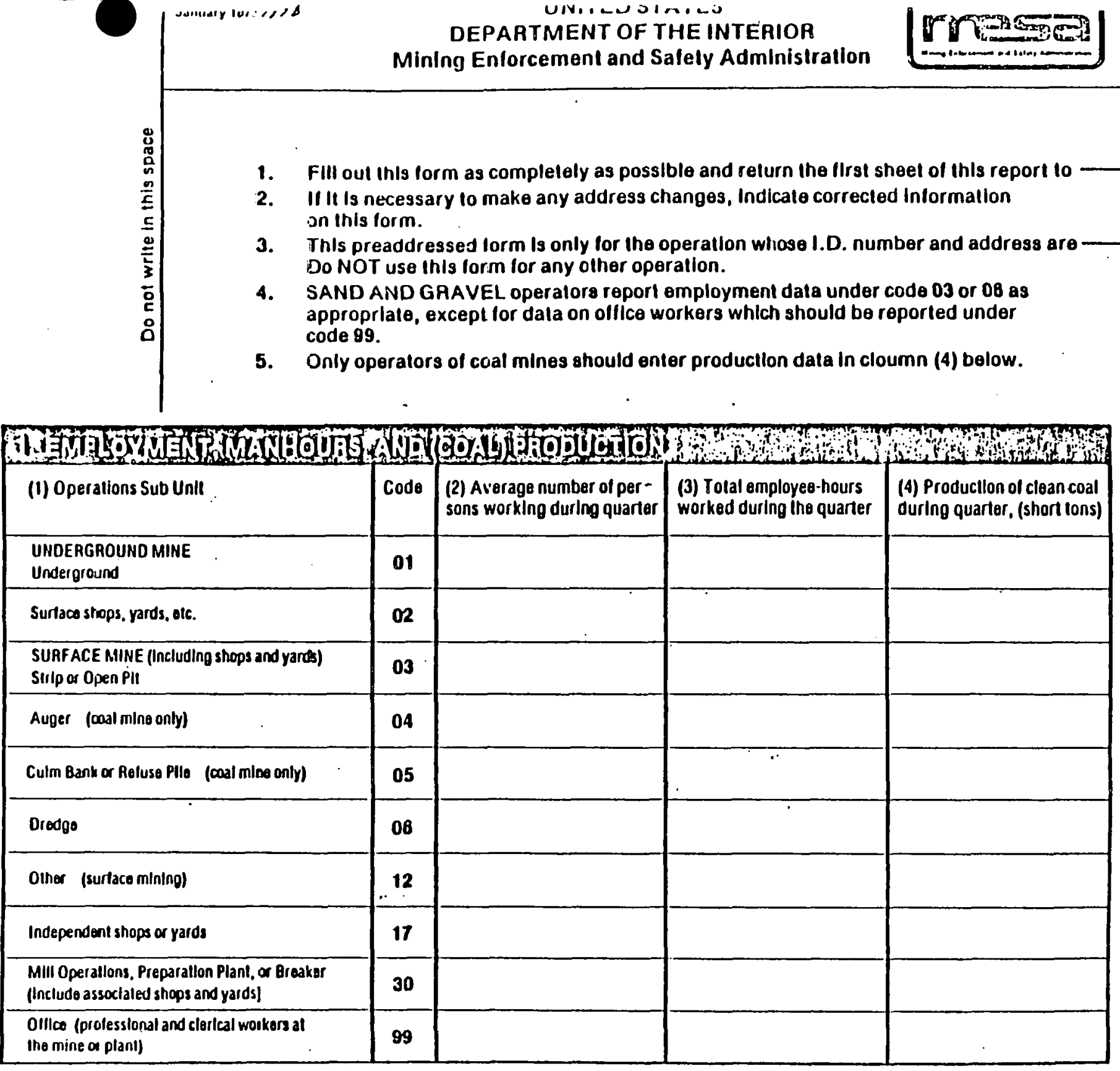

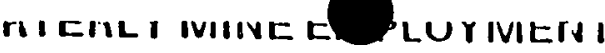
AND COAL PAODUCTION REPORT

fó

DId you have any reportable Infurles or Ilinesses durlng inls reporl perlod $\begin{array}{lll}\text { (1) } \square \text { Yes } & \text { (2) } \square \text { No }\end{array}$

MESA I.D. NO.

DATE REPOAT COMPLETED

MEALTH AND SAFETY ANALYSIS CENTER

P.O. BOX 25387, FEDEAAL CENTEA DENVEA, COLORADO 80225

I.D. NO

$\therefore \cdots$

$\rightarrow$ ADD

\section{PLANY INFORMATION BELOW IS INCOARECT PLEASE ENTEA CORAECT INFORMATION \\ COUNTY \\ TAT:ON}

operating COMPANY NAME ANO ADDRESS

IF THIS REPORT IS BEING SUBMITTED OY A CONTRACTOA ORLESSOR CHECK HERE

If Yes, lolal number of Injurles and illnesses

Person to be conlacled rogarding thls report:

\section{MINE OR PIT NAME}

OPERATINO COMPANY NAME AND ADDRESS 


\section{DEFINITIONS}

Average Number of Persons Working During the Quarter. Show the average number of employees on the payroll or other persons working during all active periods in the quarter. Include all classes of employees (supervisory, professional, technical, proprfetors, owners, operators, partners, and service personnel) on your payroll, full or part-time. REPORT EACH EMPLOYEE UNDER ONE SUB-UNII ONLY. For example: If one or more persons work both in the mine and the mill, report data on them to the sub-unit where they spend most of their time. If necessary, you may estimate for the major activity. The average number of employees may be computed by adding together the number of employees working during each pay period and then dividing by the number of pay periods. Do not include in the count pay periods where no one worked. We can use as an example a quarter with five pay periods in which employees worked. The number of employees in each pay period was $10,12,13,1.4$, and 15 , respecrively. To compute the average, add the number of enployees working each pay period $(10+12+13+14+15=64)$; divide by the number of pay periods ( 64 divided by $5=12.8$ ). Rounding 12.8 to the nearest whole number, we get 13 as the average number of persons working.

Total Employee-hours Worked During the Quarter. The total hours worked by all employees for each sub-unit reported during the quarter. The hours that should be reported are actual exposure hours worked. Report each overtime hour as one hour worked, not as the overtime multiple. Do not include vacation, holiday, sick leave, and all other off-duty time, even though paid for. The hours may be obtained from payroll or other time records if those records show straight time hours actually worked. If actual hours are not available, they may be estimated on the basis of scheduled hours.

Production of Clean Coal (Short Tons). This section is to be completed only by nperators of underground or surface coal mines, but nnt by operators of sentral or independent coal preparation plants or operators of metal or nonmeral mines. Enter the total production of clean coal from the mine. The production figure must Include coal shipped from the mine and coal used for fuel at the mine, but exclude refuse and coal produced at annther mine and purchased for use at the uine. 
Auger Mine (Coal only)

Auger mines report data on all employees and short tons of clean coal produced on the fourth line (Code 04). Include associated shop and yard employees.

Culm Bank or Refuse Pile (Coal only)

Culm bank or refuse pile operations report data on all employees and short cons of clean coal produced on the fifth line (Code 05 ). Include associated shop and yard employees.

Dredge

Dredge operations report data on employees on the sixth line (Code 06).

Enployees included are those on the dredge and all associated plant, shop, and yard employees, both dredge and land based. Coal dredge operators should report short cons of clean coal produced from dredging on this line.

Other Surface Mining (Metal/Nonmetal only)

Any other surface mine operations not included above should be reported on the seventh line (Code 12). Include associated shop and yard employees.

Independent Shops or Yards

Independent shops or yards or both are those operations not associated directly with a specific mining operation. Such operations have a unique MSHA ID number which is not shared with any other mining activity. Report data on the employees of all such operations on the eighth line (Code 17).

Processing Plants (Mill Operations, Preparation Plants, or Breakers)

Processing plants report data on all employees on the ninch line (Code 30$)$. Include crushing, sizing, grinding, concentrating, and associated shops and yards that are not a part of any mining operation and not reported under any of the above categortes.

office

Report data on all professional and clerical officeworkers at the thine or plant. The data should be reported on line ten (Code 99).

Other Reportable Daca

Indicate reportable injuries or illnesses for only the quarter being reported. If you have reportable injuries or illnesses, show the total number on the line provided; if none occurred, write "none." Reportable injuries are those for which Part 50 requires a Form $7000-1$ be submitted.

Give the name, eltle, and phone number (including area code) of the person who should be contacted regarding any data reported on the form. 
GENERAL REPORTING INSTRUCTIONS: Form EIA.7A must be submitted by all coal mining comoanies that cwried a mining oderation that produced. srocessed. or predared bituminous cọl or lịgnite during the rennrting yaar. A. ceparato form Ela.7A must be submilleu fur talih mining operation, i.e., mine and/or preparątion plant, and/or tipple.

Vining oderations that produced processed or prepared 10,000 or more short tons of coal should report as follows:

(i) For mines only or mines with preparation plants or tipples. complete all parts of the form,

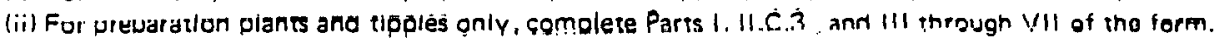

If this mining operation produced. orocessed or prepared under 10,000 short tons during the year, check this box $\square$, complete Sections 1 (Identification) and 6 (Certification) and return this form in the enclosed envelode.

Operating subsidiaries and contractors who are unable to provide the data requested should forward form ElA-7A io the parent company ut con. ifactee for comoletion prior to submission to the Energy Information Administration.

1. Idemificarion

A. Enter the Name and Address of the Reporting Mining Operation Name

8. Enter the Name and Address of the Compeny Operating this Mining Operation Name

C. Opersting Company Poim of Contact

Enter the name. title, telephore number, and address for the operating company representative who can answer questions regarding the information provided on this form.

Name Title Teleonone No. (Area Codel

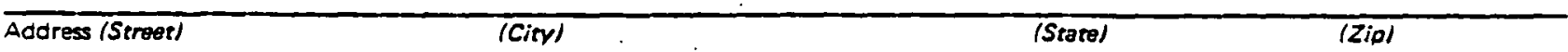

D. Type of Company Operating this Mining Operation (Check ane.) (SAee instructions for dofinitions of the Lompanty iphes.)
DIndeoendent Producer/Operator
Dooerating Subsidiary
므ontractor

E. If you checked the box tirled Operating Subsidiary or Contractor above, provide the following information about your Parent company or Contractee: (If there is more than one Parent company or contractee, provide additional names and addresses on a separate sheet of paper.) Vame of Parent CompanyiContractee

Lugress (Strset) $\quad$ TCity) (State)

F. Parent Company/Contractee Paint of Contact

Enter the name. title. teleohone number and address for the Parent company or contractee representative who can answer questions regard. ing the information provided on this form. If there is more than one Parent company or contractee. provide additional names, titles. teleonone numbers and addresses on a separate sheet of paper.

Name

\begin{tabular}{llll}
\hline Address (Streer) & (City) & (State) & (Zip)
\end{tabular}

G. Kind of Mining Operation: (Check the boxes that apply.)

ㅁi1) Underground Mine (Orift, Shaft or Slope)

$\square(2)$ Surface Mine $\square$ (a) Strio

$\square$ (b) Auger

$\square(c)$ Strip/Auger combination

EIA.7A (Rev. January!980)

D(3) Silt. Culm, Refuse Bank or Slurry Dam

[ (4) Preoaration Plant

$\square(5)$ Tipple 
H. State Permit/License/Mine Numberis) (if applicable) of mining operation reported on this form. If there are additional num. bers, use the remarks section or a separate sneet of paper to list them.

1. Mine Safery and Health Administration identification IMSHA (D) number of this mining oderation.

J. Status Change
Did mining oderation name and/or mine owner/oderator cnange during year?
i ill Yes
(2) No
If "yes." give dare of cnange

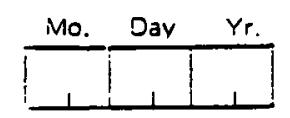

snd. as sopiicade. name of mining operation and name and address of new ownericcerator.

Yew Name of Mining Ooeration

Name of New Owner/Operator

Address of New OwneriOperator

(Street)

(Ciry)

(County)

(State)

(Zip)

11. Production

A. Coal Bed(s) Mined

Report the nameis) and thicknessiesl of each coal. bed mined during the reporting year. Exclude partings of thickness greater than one inch. \begin{tabular}{l|l|l|l|l|l}
\hline Name of Coal Bed Mined & Average Thickness of Coal Bed (in inches)
\end{tabular}

(1)

8. Recoverable Reserves

1. Enter the estimated recoverable coal reserves remaining in this mine at the end of the reporting year:

Quantity (short tons)

2. Enter the recovery percentage used in estimating recoverable coal reserves at this mine:

Report recovery percentage to the nearest whole percent.

C. Production Quantity and Value by Disposition

Recovery percentage

The company owning the coal produced at this mining operation should report, by disposition (as of the end of the reporting year). the quantity and f.o.b. value of all coal produced at this mining operation during the reporting year. The quantity and value figures reported here must reflect the condition of the coal (i.e., raw, crushed, screened. or mechanically cleaned) as of its disposition. Pedort open market disposition on a first sale basis, i.e., as of its first sale or first change in ownership. Report captive market disposition based on use. i.e.. as consumed at this mining operation, sold or transfarsed to and for usa by the oarent company or any subsidiaries of the parent company. or: " stockpiled. Calculate open market values using actual sales prices. Calculate captive market values using the actual accounting values recorded by vour company for this coal. Exclude purchased coal and refuse.

\begin{tabular}{|c|c|c|}
\hline Dispostition & $\begin{array}{l}\text { Quantity (short tons) } \\
\text { (1) }\end{array}$ & $\begin{array}{l}\text { Valuo- } \text {.o.b. mining operation } \\
\text { (dollars) } \\
\text { (2) }\end{array}$ \\
\hline $\begin{array}{l}\text { Open Market Sales } \\
i \text { Total coal oroduced at this mining operation and sold } \\
\text { to ntner coal mining companies and coal dealers/ } \\
\text { brokers (wholesale and retail) during the year. } \\
\end{array}$ & & \\
\hline $\begin{array}{l}\text { 2. Total coal oroduced at this mining operation and sold } \\
\text { to all consumers other than coal mining companies } \\
\text { and coal deaters during the year. Include sales to } \\
\text { employees. }\end{array}$ & & - \\
\hline $\begin{array}{l}\text { Captive Market UsesiSales } \\
\text { 3. Total coal oroduced and used/consumed at this } \\
\text { mining operation during the year. }\end{array}$ & & \\
\hline $\begin{array}{l}\text { 4. Total coal oroduced at this mining operation wnich } \\
\text { was sold or transferred to and for use by the parent } \\
\text { company or any other subsidiaries of the parent } \\
\text { company during the year. }\end{array}$ & . & \\
\hline $\begin{array}{l}\text { 5. Total coal produced at this mining oderation } \\
\text { which was remaining in stocks at the end of } \\
\text { the year. }\end{array}$ & & \\
\hline $\begin{array}{l}\text { Total Prnduction } \\
\text { o. Total oroduction at this mining operation during the } \\
\text { year. (Sum of } 1.5) \text {. }\end{array}$ & & \\
\hline
\end{tabular}


Report all coai, whather produced or purchased, that was in stock at this mining operation.

\begin{tabular}{l|l}
\hline & Quantity (short tonsi \\
\hline A. Total Coat Stocks at this mining oderation at the & \\
start of the year & \\
\hline 3. Total Coai Stocks at this mining operation at ine \\
end of the year
\end{tabular}

IV.Productivity

A. Manoower

Report diect labor-hours for ail emolovees at this mining oceration who were engaged in production. preparation. orocessing, development. maintenance, repair. shop or yard work at the mining operation including mining operations management and tecnnical/engineering per-

sonnel. Exclude office workers.

1. Total direct labor hours worked at this mining operation during the year. (hours)

Quantity

2. Total number of days worked at this mining operation during the year. (days)

3. Average number of emplovees per snif?.

4. Number of shifts per dav.

5. Average length of a shift. (report in hours to the nearest hundredth of an hour
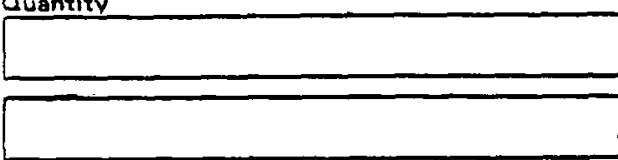

8. Producrive-Capacity

1. Productive capacity of this mining operation at the end of the reporting year. (short tons/day

2. Projected oroduction for this mining operation during next year. (short cons)

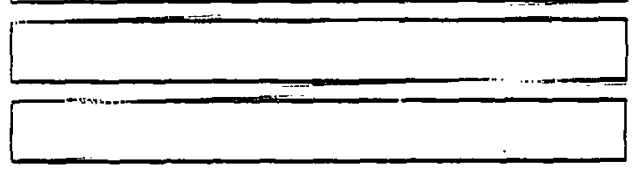

. If this mining operation includes a preparation plant, i.e., if you check box (4) in Part 1.G. of this farm, then complete the following statement:

(Chack one.)

The origin of coal prepared at this mining operation was: $\square$ (1) Underground mines only

$\square(2)$ Surface mines onity

$\square(3)$ Both

V. Disctosure Statement

PLEASE READ SECTION H 2 OF THE SPECIFIC INSTRUCTIONS BEFORE COMPLETING THESE QUESTIONS.

A. Does the information supplied on this form contain trade secrets and/or privileged or confidential commercial or financial information? $\square$ Yes $\square$ No

B. Have you attached a written justification for exemption from the Freedom of Information Act (FOIA)?

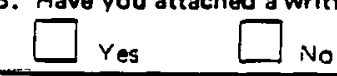

VI. Cartifleationt

This part of the form is to be completed by the official of the reporting company empowered to certify the truth and accuracy of the information provided on this form. Print or type the name and titte of the certifying official. The certifying official must sign and date the certification.

I certity that the information provided herein and appended herero (if any) is true and accurate to the best of my knowledge.

Name Titie Signature and Date

Title 18 USC 1001 makes it a crime for any person knowingiv and willfully to make to any department or agency af the United States any false, fraudulent statements or representations as to the matter within its jurisdiction.

VII. Remarks

Uee thio port of the form for additional space, explanations where necessary, or to request the ElA report summarizing data from this survey, additional forms or business reply envelodes. 


\section{A. Purpose}

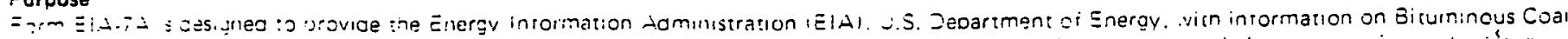

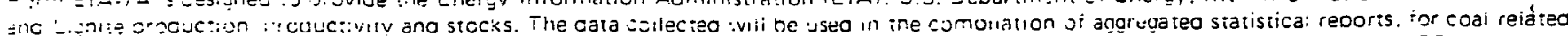

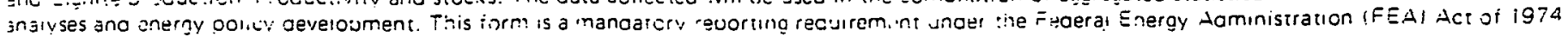
$F$.. 33.275 ! and ine Powerplant zno Inaustriai $\bar{r}$;el Use Ac: Ji :978 (P L. 95.020$)$.

\section{Who Must Submit}

= arm $\equiv i A . i A$ must be submirted oy all coal minirig comoanies that owned a mining oderation inat oroduced. processed or prebared bituminous coal or

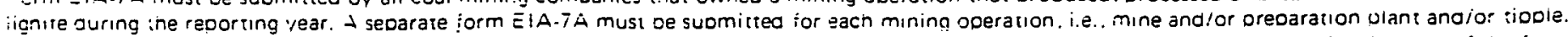
Mining operations that oroduced. processed. Or prepared 10.000 or more short tons of coal during the year must comulete all applicable parts of the form whereas thcse that produced, processed or preoared less than 10.000 short tons of coal during the year must complete only Parts I (ldentification) and VI (Certification).

\section{Where to Submit}

Form EIA.TA snould be returned in the ousiness reply envelope provided with the form to:

Energy Information Administration, El-34

Mail Station: 8G-086, Forrestal.

U.S. Department of Energy

Wasningron, D.C. 20585

Zequests for further iniormation, aditional forms, or ousıness revly envelopes should be direcred to :se zadress abore or by reteonone to (202) 252.6881.

D. Whon to Submit

Form EIA.7A must be submitted by February $15 \mathrm{ch}$ of the year following the revorting year.

\section{E. Sanctions}

The timely submission of form ElA.7A by a combany required to report is a mandatory requirement. Lare filing, fatiure io file. or farlure otherwise to make intormation available to EIA in accordance with these illstructions. mav result in criminal fines. civil penalties and other sanctions as provided bv Section i3(i) of the FEA Ac: (P L. 93-275).

\section{F. Definitions}

1. Auger mine-a surtace inine in which the coal is removed trom the coal bed by means of a large diameter arill. Usually operated onily when the overburden becomes too thick lor economical strip mining.

2. Captive coal-dil coai croduced and consumed by the independent producer/operator or operating subsidiary or procuced for consumption by a parent combany.

3. Coal bed $\rightarrow$ beo or stratum of coal. Also called a coal seam.

4. Drift mine- a mine that opens horizontally into the coal bed or cral outcroo.

5. f.o.b. (Free On Boardl mining operation value-the price of coal at the mining operation. Does not include ireight or shipping costs.

6. Independent producer/operator-a company which operates a coal inıning operation and has no overating subsidıarıes or parent companies.

7. Mining operation-a inıne and/or preparation plant and/or tıpple at a singie physical location having a single iNine Safety and Health Administration IMSHAl identification number.

8. MSHA 10 number-seven (7) digit code assigned to a minıng operation by the Mine Safety and Healtn Administration (MSHA).

9. Open market coal-coal sold in the open market. i.e., coal sold to comounies other than the reporting company's parent company or an uderating subsidiary of the oarent company.

10. Operating subsidiary-comoany which operates a coal mining operation and is owned by another comoany (i.e.. the parent crmoany).

11. Parent company -a company which solely or joinity owns a subsidiary which operates a coal mining operation and is not owned itself by another company.

12. Report year-ihe calendar year beginning at 12:00 a.m. January 1 and ending at 11:59 o.m. December 31

13. Shaft mine-a mine that reaches the coal bed by means of a vertical opening.

14. Slope mine $\rightarrow$ mine that reaches the coal bed by means of an inclined opening.

15. State permit/ticense/mine number-code assigned to a mining operation by the state in which the operation is located.

16. Strip mine- an open cut mine in which the overburden is removed from a coal bed pritor to removal of the coal.

\section{G. General Instructions}

Mining operations that produced. processed or prepared less than 10.000 short tons of coal during the year check the appropriate box above Part 1 of the form and comolete Parts I lldentification) and VI (Cerification).

Vines only a mine with prebaration plants or unples that produced 10.000 or more short ton's or coal during the year complete all parts of the form.

Preparation plants or tipples only that prepared or processed 10,000 or more short tons of coal during the year complete Parts I. II.C.3. and III through VII of the form.

Pedort all quantities in short tons $(2.000$ pounds), io the nearest whole ton. Report value in dollars to the nearest collar. Operating subsidiaries and contractors who are unable to provide the data requested should forward form ElA.7A ro the parent comoany or contractee for combletion prior to jubmission io ine Energy Information Administration.

\section{H. Specitic Instructions}

\section{i. Disciosure of Information}

The information contained on these forms mav be (i) information which is exempt from disclosure to the oublic under the exemption for trade secrets and confidential commercial information specified in the Freedom of Information Act (FOIA) 5 U.S.C. 552 (b) (4) or (ii) pronibited from Dublic release bv 18 U.S.C. 1905. However. before a determination can be made that particular informaticn is within the coverage of either of these statutory orovisions. the person submitting the information must make a showing satisfactory to the Department concerning its confidential nature.

Therefore, you snould state briefly and soecifically (on an element by element basis if possible), in a letter accompanying your submission of the form. why ycu consider the information concerned to be a trade secret or other proprietary information. Ninether such information is customarilv ireated as conficential by your company and the industry, and the type of competitive harm that would result to vour company irom disciosure of the iniormation.

In accordance with the provisions of 10 C.F.R. 1004.11 of DOE's FOIA regulations, DOE will determine whether any information submitted should be witnheld from public disciosure.

If DOE aoes not receive a request for exemption from you, it will assume that you do not objec: to oublic disclosure of any information submitted on this form oy your combany.

By statutory authority DOE must provide this information, when requested to the Congress or any Committee of Congress and the General Account. ing Office. 
-

tnergy Informasion Adatnicetration

Coke plone kadost - Querterty

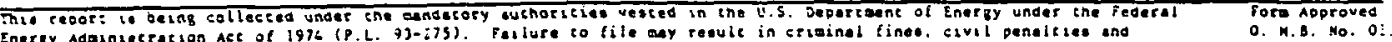
Enerey Adestater cion ouboscted on tBis tom. See secsion vill of the inecructiona.

1. RESPONOENT IOENTIFICATION

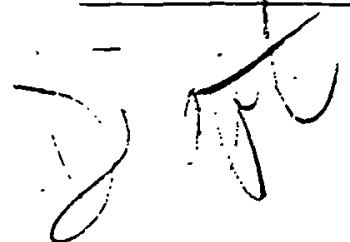

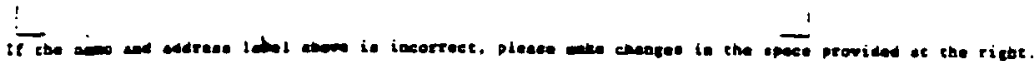

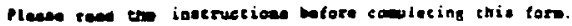

11. Coning coele

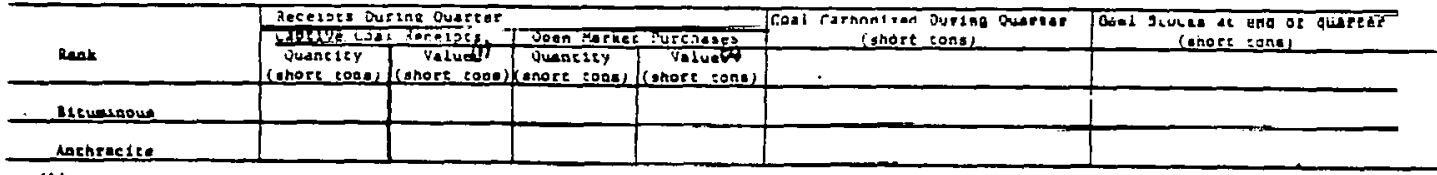

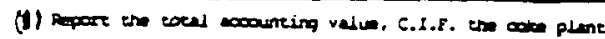

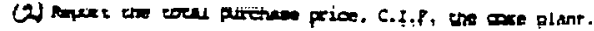

III. Cole sou sremse

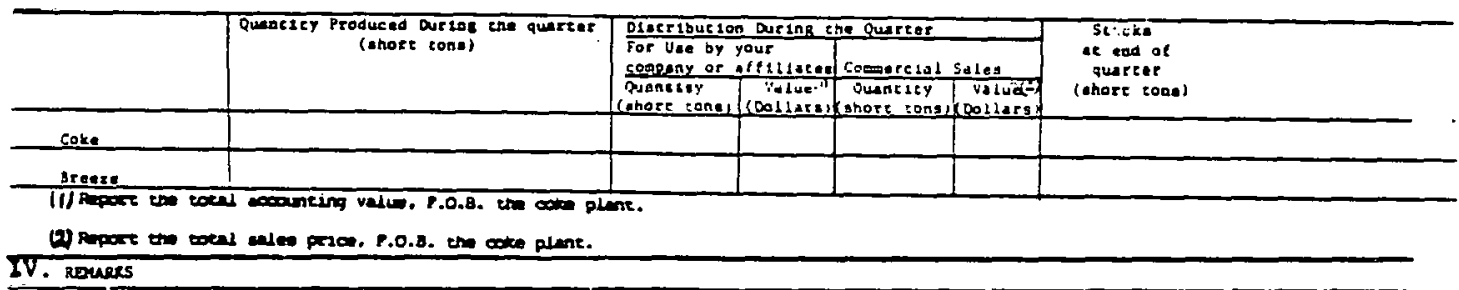

IV. RDuses

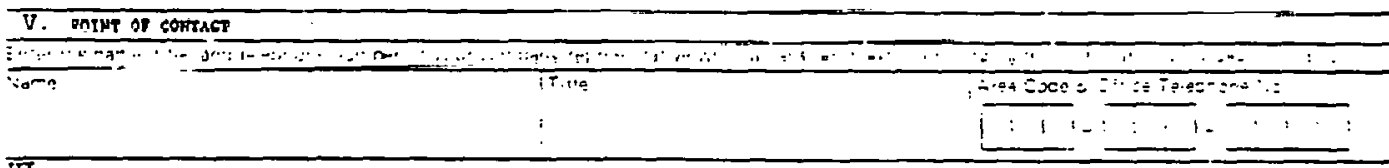

VI.comportulitr statereort

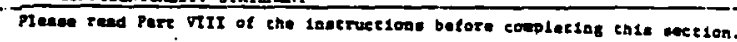

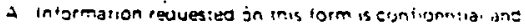

$\therefore$ in:eases will cause suostantiat comnefitive injur:

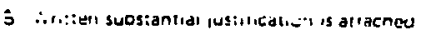

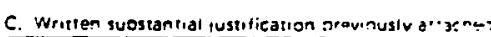

\section{Ginncarior}

$$
\begin{aligned}
& -\cdot- \\
& ={ }^{-1}= \\
& --
\end{aligned}
$$

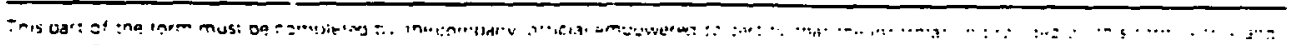

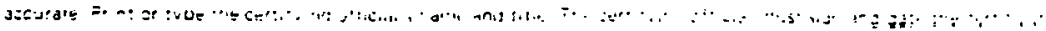

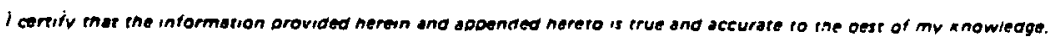

vima

$T: !$

Siunature

$\vdots \mathbf{j}:$

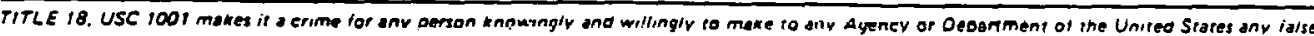
fietrious or fraudulent starements as to anv matrer wienin irs ufrisorction.

EIA-5 


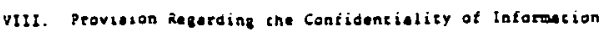

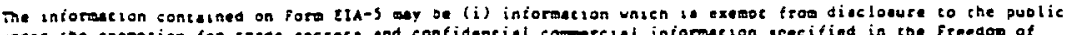

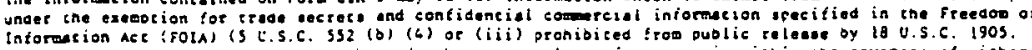

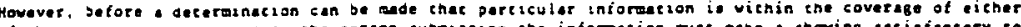

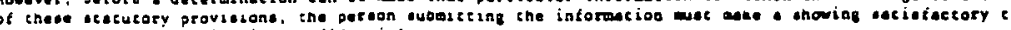
the Departsens concerning iso contidential naturo.

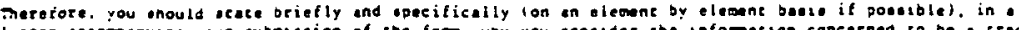

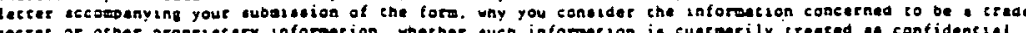

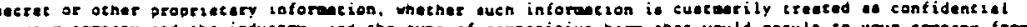

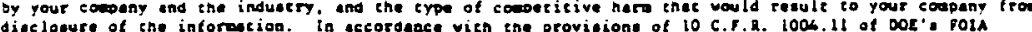

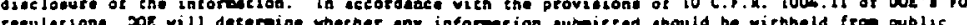

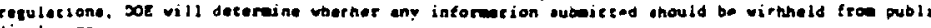

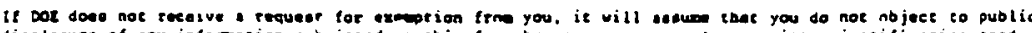

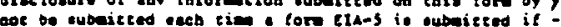

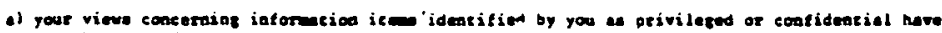

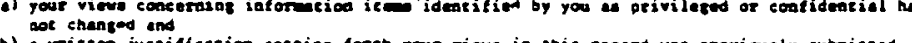

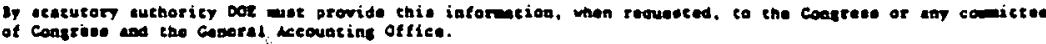

\begin{tabular}{|c|c|c|c|c|c|c|c|c|}
\hline \multirow[t]{2}{*}{$\overrightarrow{\mathrm{Cl}}$} & \multirow[t]{2}{*}{ Grovo } & \multicolumn{2}{|c|}{ 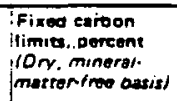 } & \multicolumn{2}{|c|}{ 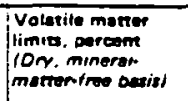 } & \multicolumn{2}{|c|}{ 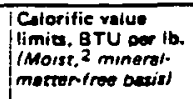 } & \multirow[t]{2}{*}{$\begin{array}{l}\text { Aggiomerning } \\
\text { icherecier }\end{array}$} \\
\hline & & $\begin{array}{l}\text { Equal or } \\
\text { greater } \\
\text { inan }\end{array}$ & $\mid \begin{array}{l}\text { Less } \\
\text { than }\end{array}$ & $\begin{array}{l}\text { Greater } \\
\text { inan }\end{array}$ & $\left\{\begin{array}{l}\text { Equal or } \\
\text { Lens: } \\
\text { thon }\end{array}\right.$ & $\begin{array}{l}\text { Eausl or } \\
\text { greater } \\
\text { inan }\end{array}$ & | Lest & \\
\hline \multirow[t]{3}{*}{ 1. Anthrasitic } & 1. Meta-aninracite & 98 & - & - & 2 & - & - & \multirow{3}{*}{ Non-oggiomerating } \\
\hline & 2. Aninracite & 92 & 98 & 2 & $\mathbf{8}$ & - & - & \\
\hline & 3. Semiantnrocite ${ }^{3}$ & 86 & 92 & 8 & 14 & - & - & \\
\hline \multirow[t]{6}{*}{ II. Bituminous } & 1. Low-vasatile bituminous coal & 78 & 86 & 14 & 22 & - & - & \multirow{5}{*}{ commoniv, aggiomeraungs } \\
\hline & 2. Medium.volettle bituminous coat & 69 & 78 & 22 & 31 & - & - & \\
\hline & 3. Hign-volatile A oituminous coal & - & 69 & 31 & - & $: 4,000^{4}$ & - & \\
\hline & \multirow[t]{2}{*}{4 Mign-volatile 8 bituminous coaı } & \multirow[t]{2}{*}{-} & \multirow[t]{2}{*}{-} & \multirow[t]{2}{*}{-} & \multirow[t]{2}{*}{-} & $13.000^{\circ}$ & 14.000 & \\
\hline & & & & & & $\int 11.500$ & 13.000 & \\
\hline & 5. High-volatule $C$ bituminous coal & - & - & - & - & $\{10.500$ & 11.500 & Aggıomerating \\
\hline \multirow[t]{3}{*}{ III. Suboiruminous } & 1. Subortuminous A coal & - & - & - & - & 10.500 & 11.500 & \\
\hline & 2. Subdituminous $B$ coal & - & - & - & - & 9.500 & 10.500 & \\
\hline & 3. Suboituminous $C$ sObi & - & - & - & - & 8.300 & 9.500 & 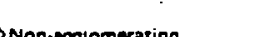 \\
\hline \multirow[t]{2}{*}{ IV. Lignitic } & 1. Lignite A & - & - & - & - & 6.300 & 8.300 & \\
\hline & 2. Lignite 8 & - & - & - & - & - & 6.300 & \\
\hline
\end{tabular}

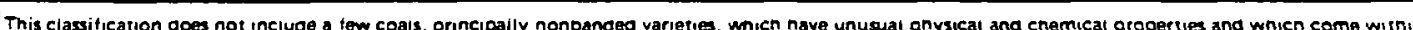

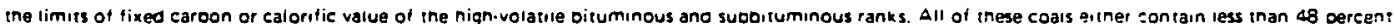
an. mineral.matter.tree tixed caroon, or have more than 15.500 gritish thermal units Der oound. calculated on ine moist, mineral.matter.tree dasis.

2.Moist reters to call containing is naturat innerent moisture out not including visibie water on the surface of the coal.

It aggiomerating, ctassity in low-volatile grous of the bituminous clas.

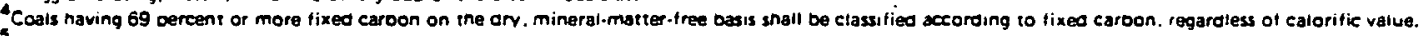

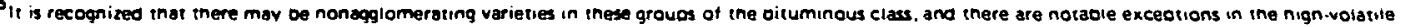

C bituminous groud. 
Energy Sntorgecion Adasnistration

1. Puroone

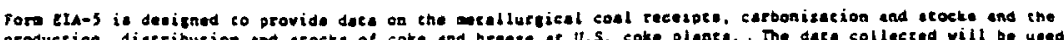

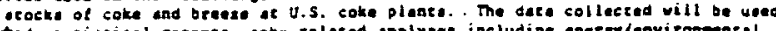

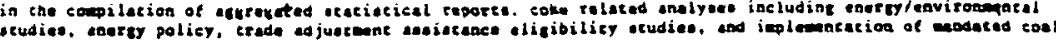
propean.

11. the nust subaic

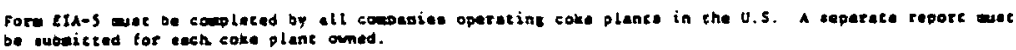

III. Snen to Subeis

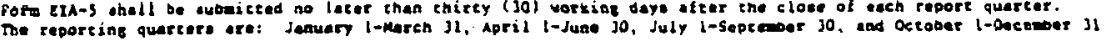

IV. Unere to Subast

Subait one copy so:

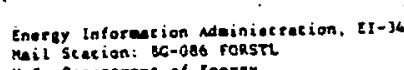

U.S. Depurtment of Eneray
Weothington, o.c. 20sss

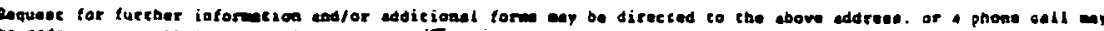

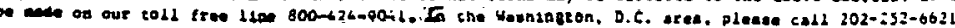

v. Seactione

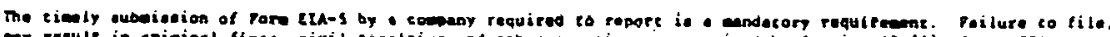

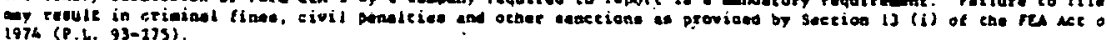

4t. Ganeral inocruerione

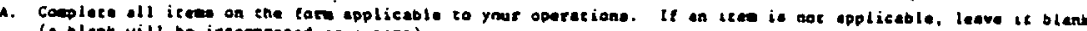
(1) olank vill be idecerpreted at a zero).

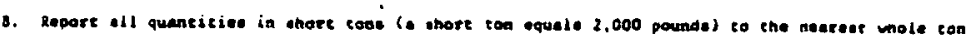

c. Repose all valuet is dollar, to the netreat mole daller.

viz. Definiciane

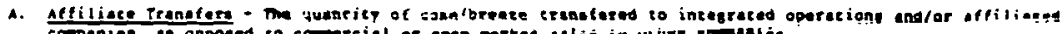

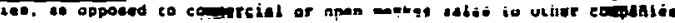

B. Anenrecite conl - Sae table 1 below.

c. Biruninove cael - soe sable 1 below.

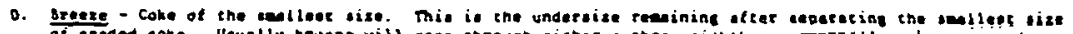

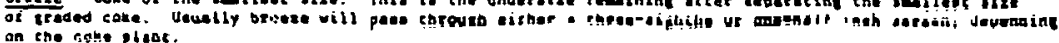

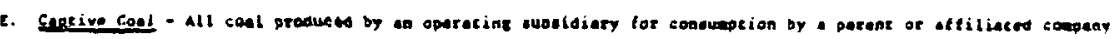

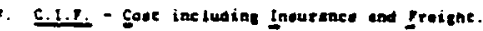

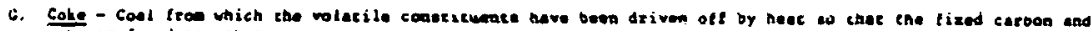
ins are luned colochee

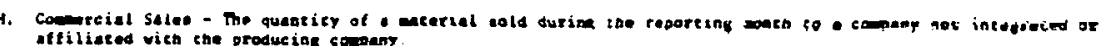

1. P.0. - Iree on sourd.

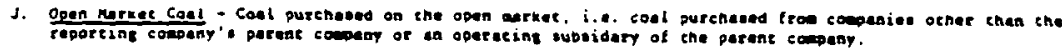




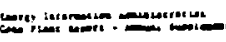

a.s.

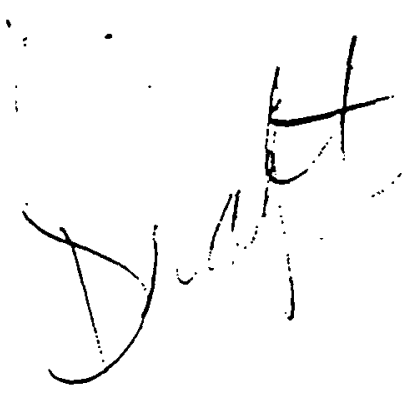

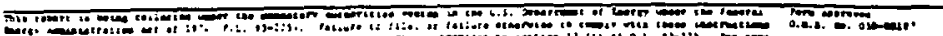

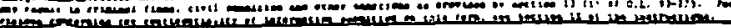

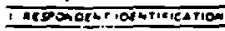

-

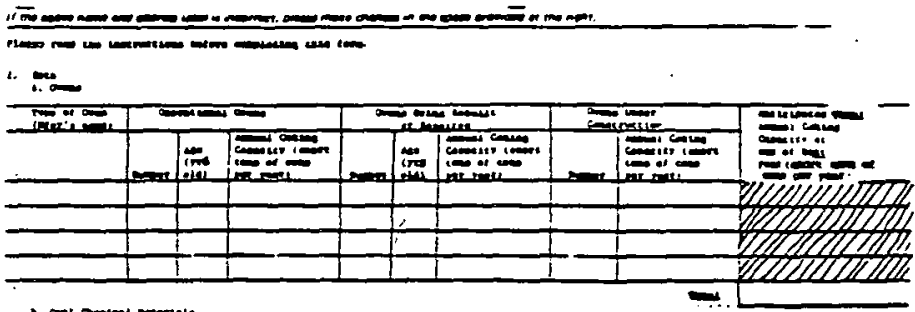

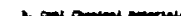

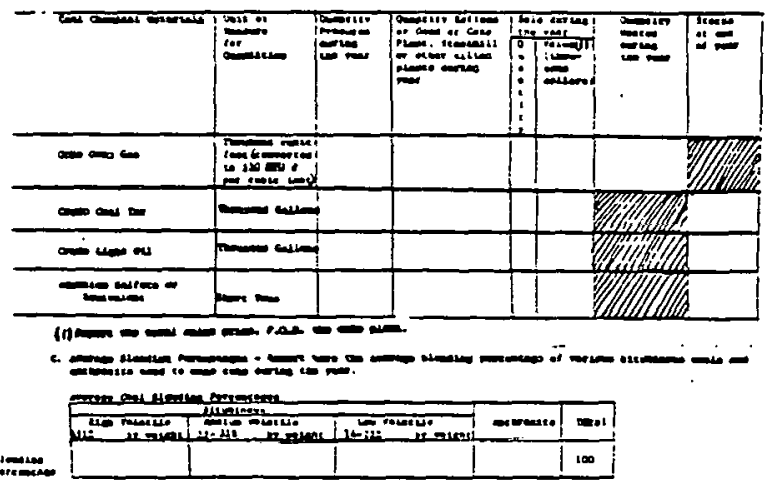

(1)

Irfinaaㅗ

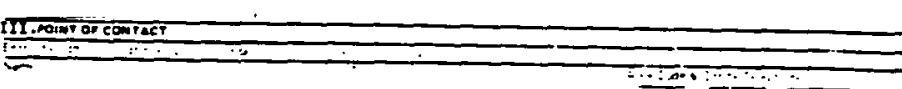

Iv
1.

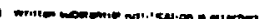
$\equiv=$

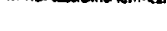
$\because \cdot \boldsymbol{n}$
$=$ =

Texprifreario

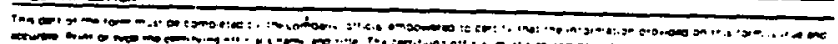

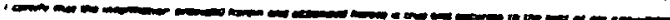

-

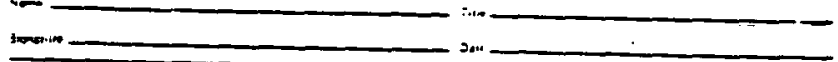

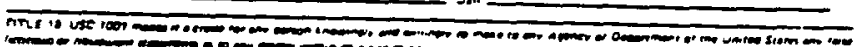
เu-sa

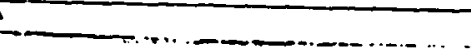




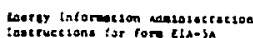

:astructions :sr ron clis-sh

t. Pucoose

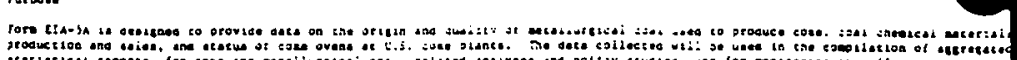

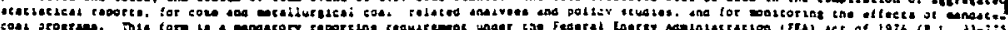

11. mo snocis sumass

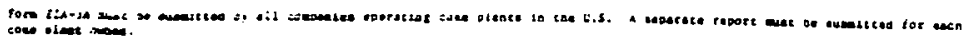

111. nore co suele

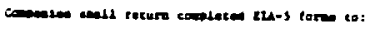

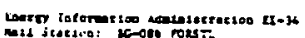

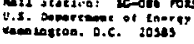

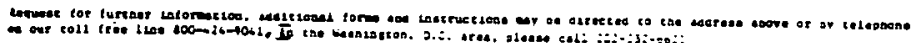

iv. wee to subart

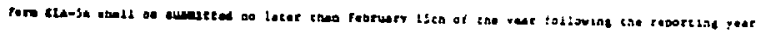

7. Sacessone

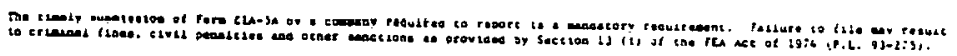

v. Det testione

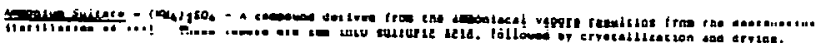

manrocike cuet - 100 table 1 beloo.

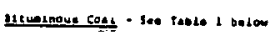

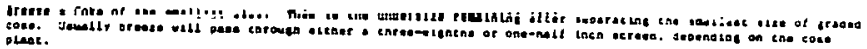

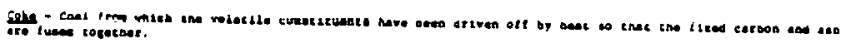

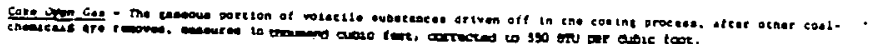

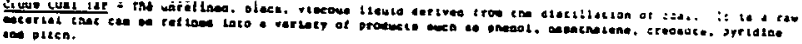

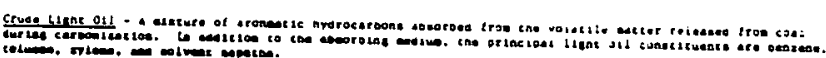

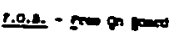

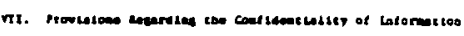

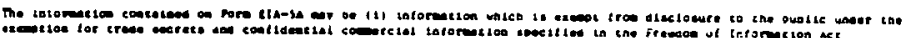

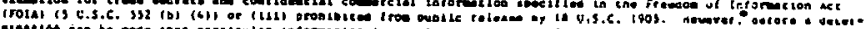

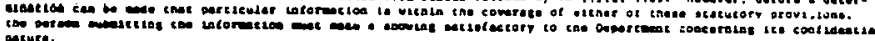

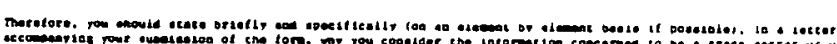

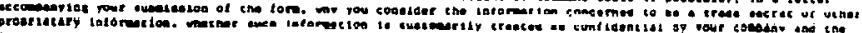

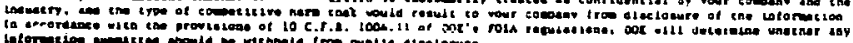

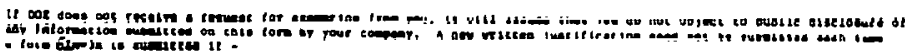

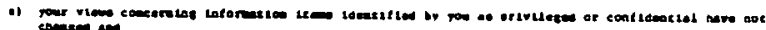

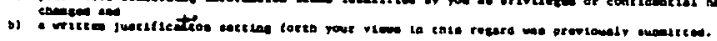

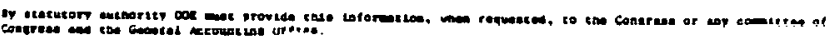

\begin{tabular}{|c|c|c|c|c|c|c|c|c|}
\hline \multirow[t]{2}{*}{ en } & \multirow[t]{2}{*}{ anenes } & \multicolumn{2}{|c|}{ 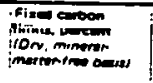 } & \multicolumn{2}{|c|}{ 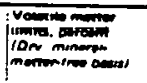 } & \multicolumn{2}{|c|}{ 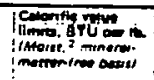 } & \multirow{2}{*}{$\begin{array}{l}\text { onemen } \\
\vdots\end{array}$} \\
\hline & & 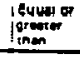 & $i^{\text {Inen }}$ & $\operatorname{liman}^{1}$ & $\left.\right|_{\operatorname{liman}} ^{\text {Geser or }}$ & 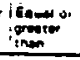 & $\operatorname{lom}_{\operatorname{man}}$ & \\
\hline \multirow[t]{2}{*}{ isninecertic } & 1 Motenenmrecite & จด & - & . & 2 & - & $=$ & \\
\hline & 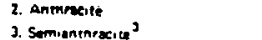 & $\begin{array}{l}72 \\
36\end{array}$ & $\begin{array}{l}98 \\
92\end{array}$ & 2 & 3 & - & - & von.opgiomert \\
\hline \multirow{5}{*}{ "1. Blitumitions } & 1 Lom-vostim ortuminous conl & : & & & & & & \\
\hline & 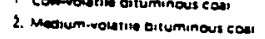 & 69 & $\begin{array}{l}36 \\
78\end{array}$ & $\begin{array}{l}14 \\
: 2\end{array}$ & 32 & 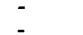 & $\dot{-}$ & . \\
\hline & 3. Mion-vasarive A Dituminous seal & $=$ & fa & it & & $14000^{\circ}$ & . & 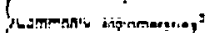 \\
\hline & 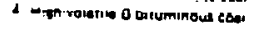 & - & - & - & - & $: 3.500^{\circ}$ & 14000 & \\
\hline & 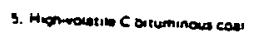 & - & - & - & - & $\left\{\begin{array}{l}11.500 \\
10.500\end{array}\right.$ & $\begin{array}{l}13.000 \\
: t .500\end{array}$ & 2opomeroting \\
\hline \multirow[t]{3}{*}{ I" Sweornmminars } & 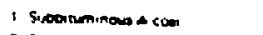 & - & - & - & - & & & \\
\hline & 2. Sucortuminows a cose & - & - & - & - & $\begin{array}{l}10.9000 \\
9.500\end{array}$ & 10.500 & \\
\hline & J. Scooituminous $C$ cosi & - & - & - & - & 9.300 & $9 \operatorname{son}$ & \\
\hline \multirow[t]{2}{*}{ 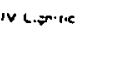 } & $\cdot \operatorname{lng}(\tan 2)$ & - & - & & & & & \\
\hline & 2. bonte = & - & - & - & - & -2 & $\begin{array}{l}0.300 \\
0.300\end{array}$ & \\
\hline
\end{tabular}

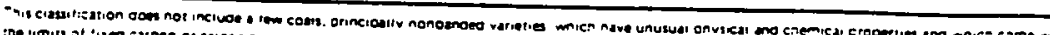

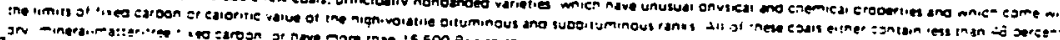

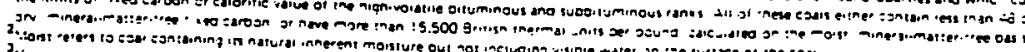

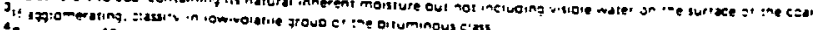

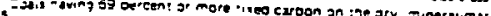

G 
Plesse make any corrections co mis mailing labes in the sasce provided at the right. Pleme resed the instruetiors on the reverse side before comptering this form.

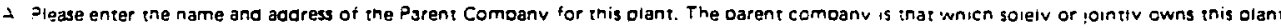
Ind whicn is not utself the suosidiary of another comoanv. If there are acditional oarent somoanies for this olant. atease give thesr names 3na adcresses on a seoarate Diece of paner. vame

Address (Streat) TCiryt IZio Codel

3. Please enter the name. dodress, title and teleshone number of the olant of oarent comoany reoresentative wno can answer questions regarding ine iniormation orovideo on this form.

\begin{tabular}{|c|c|c|}
\hline Name & Title & Tel. No. LArea Codel \\
\hline Aedress (Seroer) & (Ciry) & (Zip Code) \\
\hline
\end{tabular}

II. Coal A weripts. Consumption, and Stocks

- Cumolete all data items abolicable to this olant. Blanks will be interoreted as zeroes.

- Do not reoort coal usec to oroauce coke.

- Reoor quantities in whole snort tons 12.000 Dounosi ano costs in dollars.

- C.I.F. means Cost incluating Insurance ano fereight.

- In Seot Purenases (columns $C$ and Di. report coal ourenased on the oden market, i.e., not under an existing contract.

- In Ner Stock Adiustment (columns F. G and HI. report the net cnange in stocks during the quarter resulting trom anv revisions to the orevious auarer's enaing stock estimate lcolumn II. and any stock losses, transfers of coal stocks to other olants owned by ine same oarent company or sales of coal srocks to oiner comoanies.

\begin{tabular}{|c|c|c|c|c|c|c|c|c|c|}
\hline \multirow{2}{*}{ 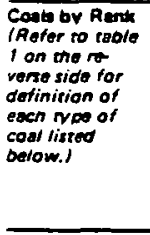 } & \multicolumn{2}{|c|}{$\begin{array}{l}\text { Recaipts } \\
\text { Contract Purenases }\end{array}$} & \multicolumn{2}{|l|}{ Spor Purchases } & \multirow{2}{*}{$\begin{array}{l}\text { Comaump- } \\
\text { tion } \\
\text { Quantity of } \\
\text { coal Con- } \\
\text { sumed Dur- } \\
\text { ing ino } \\
\text { quarter } \\
\text { fshon tons) } \\
\text { (e) }\end{array}$} & \multicolumn{3}{|c|}{$\begin{array}{l}\text { Stocks } \\
\text { Net Stock Adiustment }\end{array}$} & \multirow{2}{*}{$\begin{array}{l}\text { Stocks at } \\
\text { the End } \\
\text { of the } \\
\text { Quarter } \\
\text { (shor } \\
\text { coms) } \\
\text { (1) }\end{array}$} \\
\hline & $\begin{array}{l}\text { of Coai fie- } \\
\text { ceived during } \\
\text { the Quarter } \\
\text { (shor rons) } \\
\text { (A) }\end{array}$ & $\begin{array}{l}\text { Coal Received } \\
\text { on a C.I.F. } \\
\text { basis } \\
\text { (dollanal } \\
\text { (a) }\end{array}$ & $\begin{array}{l}\text { of Coal Re- } \\
\text { ceived during } \\
\text { the Quarter } \\
\text { isnore tonst } \\
\text { (c) }\end{array}$ & $\begin{array}{l}\text { Coal Received } \\
\text { on a C.I.f. } \\
\text { oasis } \\
\text { follsers } \\
\text { (0) }\end{array}$ & & $\begin{array}{l}\text { Troe } \\
\text { lcheck on } \\
\text { Addl. } \\
\text { tian i+1 } \\
|F|\end{array}$ & $\left\{\begin{array}{l}\text { Roodue. } \\
\text { tion i-t } \\
\text { (c) }\end{array}\right.$ & $\mid \begin{array}{l}\text { Quantity } \\
\text { (short tons) } \\
\text { (n) }\end{array}$ & \\
\hline \multicolumn{10}{|l|}{ Bituminous } \\
\hline \multicolumn{10}{|l|}{ Subbituminous } \\
\hline \multicolumn{10}{|l|}{ Lignite } \\
\hline Antnracite & & & & & & & & & \\
\hline
\end{tabular}

Nas caal consumed for ine procuction of electricitv auriny the reoorting guarter? $\square$ Yes $\square$

\section{Oisetocure Strement}

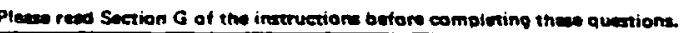

Does the information sudosied on this form contain trace secrets andor orivileged or confidential commerctal or financial in formation? $\square_{\text {Yes }} \square_{\text {No }}$

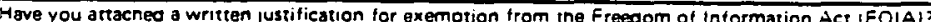

$\square_{\text {Yes }} \square$ No

H\&s a written justification for exemption from ine FOIA been previousiv submittea?

Wyes. cate

iv. Certification

This oart of ine form is to de comoleted bv ine otficial oi the reporting comoanv emoowered to cersity ine truth and accuracv of the :niorma. tion orovided on this form. Print or tvoe name and title of the certifying official. The certifving official must sign ano date the certification.

I cernty that the intomation provided herein and spoended herevo (if any) is true and accurate to the best of my knowtedge.

Name Tille Sig̣nature Date

Ttie 18 USC 1001 makes ir a orime for ony person kinuwingly and willfuily to make to any oedonment or agancy of the Uniced Stares any fa/se. Fravoulent starementr of represenestions as to the motter within irs iurisoliction.

EiA.3 'Rev. January 1980$)$ EIA (Whito CopyI - RESPONDENT (Yollow Copy) 
A. Purdo:

Form E tA.3 is designed to orovide information on coal used for generating neat and electricitv and processing raw or manuiactured materrais by manu. facturers. This reDor is necessary for " fulty iniomea monitoring and guicance" bv ine Energy iniormation Admihistration (E)Al in accorcance witn

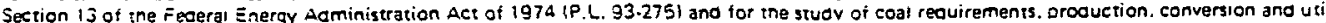
tion mancated oy Sections 741 and 742 of the Powerdiant and industrial Fual Use Act of 1978 (P.L. 95-620).

8. Who Shall Submit

Form EIA-3 snatl be sudmitteo ov all manuiacturing comoanies that consume antnracite, bituminous. sudbituminous coal or lignite for all uses orner Dan cora yollow copy.

C. When to Submin

Form ElA.3 must be submitted no later than thirv (30) days after the end of the reborting quarter. The redorting quarars are: January 1-Maren 31 (first). Adoril i June 30 (seconal. July 1 -September 30 (thira) and Ocrober 1 -Oecember 31 (fourth).

D. Where to Submit

The ElA-3 shovid be returned in the business redly envelope orovided with the form. If you do not receive an envelode, Dlease send form ElA-3 to: Enorgy information Administration, El-34 Mail Station: BG-086 Forat U.S. Department of Enerty Washington, O.C. 20585

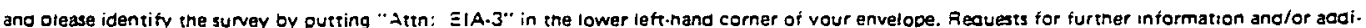
ional forms. instrustions, or ousiness reply envelodes may oe oirecteo to the sodress acove or oy teteonone to 12021252.6868 .

E. Sunction

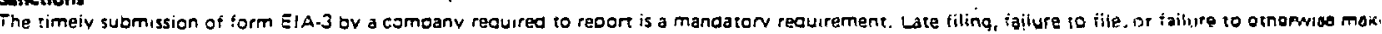

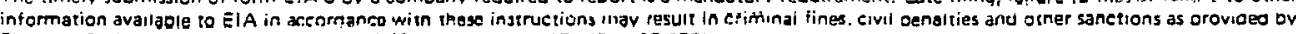
Section 13 (i) of the Feoeral Energy Administration Aet of 1974 (P. L. 93.275 ).

F. Batinitiours

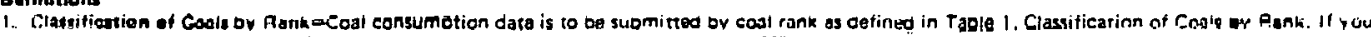

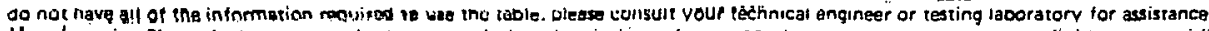

2. Manutaczuring Plant-A plant engaped in tha mocnanical or chemical transiormation of materials or substancea into finishea or semi-finished materials ur orocuets.

3. Primary Product-The orimary nrndurs manuisoturea at ine blallt.

\section{b. Dixcionure of Intormation}

The information contained on these forms may de (i) information which is exemot from disclusure to the oublic uncer ine exemotion for trace secres and coniddential commercial information soecified in the freedom oi intormation ACt IFOIA). 5 U.S.C. $\$ 52$ (b) (4) or tiil pronioited trom aualic retease by 18 U.S.C. 1905. However. Defore a determination can oe made that jarticular information is within the coverage of eitner of these statutory orovisions. the derson suomirting the information must make a snowing satrsfactory to the Deoartment concerning its confidert riat nature.

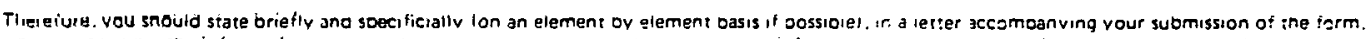
why you consioer the information concerned to de a trage secret or other proprtetary information, wnather such in formation is custornarily treateo as

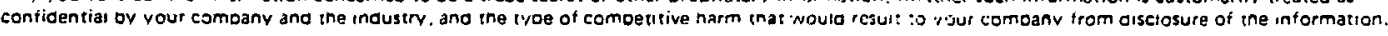

In accordance with the provisions of 10 C.F.A. 1004.11 of DOE's FOIA regulations. DOE will determine wnether any information submitted snould De witnneld from oublic disclosure.

If DOE does not receive a request for exemotion from you. it will assume that you dn nas soject to oublic disclosure of anv information submitted on this form DY your camosny. A new written justification need not be submintec each time form ElA-3 is submitted if:

a. your views concerning intormaxion itams identified by vou as privilegeo or contidential have not enanged ano

D. a written justification setting foran your views in this regara was oreviously submi neo.

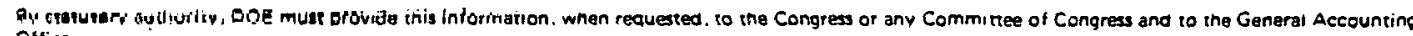
Osfice.

\begin{tabular}{|c|c|c|c|c|c|c|c|c|}
\hline Clen & Group & 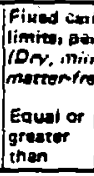 & 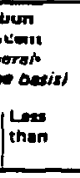 & 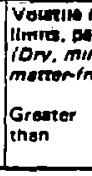 & 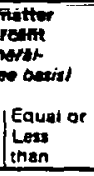 & $\begin{array}{l}\text { Caloorifie } \\
\text { limier, 61 } \\
\text { Moist? } \\
\text { matren in } \\
\text { Equal or } \\
\text { greater } \\
\text { eman }\end{array}$ & 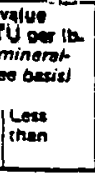 & Aqumming \\
\hline \multirow[t]{3}{*}{ I. Anthracitic } & 1. Meta.enthracite & 98 & - & - & 2 & - & - & \\
\hline & 2. Anthracite & 92 & 98 & 2 & 8 & - & - & Non-sgglomerating \\
\hline & 3. Semianthrecire ${ }^{3}$ & 86 & 92 & 8 & 14 & - & - & \\
\hline \multirow[t]{6}{*}{ 1I. Ainuminnuנu } & 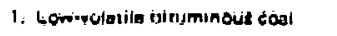 & 78 & 86 & 14 & 22 & - & - & \\
\hline & 2. Meaium-volatile bituminous coal & 69 & 78 & 22 & 31 & - & - & \\
\hline & 3. High-volatila A bituminous coal & - & 69 & 3 & - & $14,000^{4}$ & - & Commonlv, aggiomeratıng ${ }^{5}$ \\
\hline & 4. High-volatile 8 bituminous coal & - & - & - & - & $13.000^{4}$ & 14.000 & \\
\hline & & & & & & $\{11.500$ & 13.000 & \\
\hline & 5. Hign-volarile C bituminous coal & - & - & - & - & 10.500 & 11,500 & Agglomerating \\
\hline \multirow[t]{3}{*}{ III Subbiruminous } & 1, Juivinimimingijt $n$ eosi & $=$ & - & - & - & 10.500 & $11.500)$ & \\
\hline & 2. Subbituminous $8 \mathrm{cos}$ & - & $=$ & - & - & 9.500 & 10.500 & \\
\hline & 3. Subbituminous $C$ coal & - & - & - & - & 8.300 & 9.500 & Non aglomerating \\
\hline \multirow[t]{2}{*}{ IV.Lignitic } & 1. Lignite A & - & - & - & - & 6.300 & 8.300 & \\
\hline & 2. Lignite 8 & - & - & - & - & - & 6.300 & \\
\hline
\end{tabular}

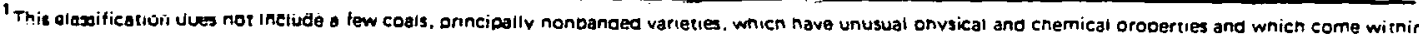
the limits of fixed carbon or caloritic value of the nigh-volatile oituminous and suboituminous ranks. All oi these coats eilner contain tess than 48 sercent an, minerat-matter-free fixed carton. or nave more than 15.500 gritisn thermal uniss per oounc. caiculated on the moist, mineral-matter-free oasis. 2 Moist refers to coal con taining irs natural innerent moisture but not inctuang visible water on the suriace of the coal.

3 it aggiomerating. classify in low-volatile groud of the gituminous class.

${ }_{5}^{4}$ Coals naving 69 oercent or more tixed carbon on the arv. mineral.matter ffee basis snall be classified according to iixed carbon. isgardless of caloritic vall

It is recognized that there mav te nonagglomerating varieties in these grouvos or ine dituminous c:ass. ano :nere are notadie urceotions in the nign.volatile

Cituminous arous. 
m OSM 837.1 jvemoer 19771

\section{DEPARTMENT OF THE INTERIOR OFFICE OF SURFACE MINING Reclamation and Enforcement}

ADProved by GAO

B.190462 (RO483)

Expires: $12 / 31 / 78$

COAL PRODUCTION AND RECLAMATION FEE REPORT

REAO INSTRUCTIONS BEFORE COMPLETING THIS FORM

sreprinted ir.formation is incorrect or missing make corrections or additions in item only. Jo nor write in items 18 .

Name and mailing address of operato

- Caiendar auarter ending

a. $\square$ March 31

๖. $\square$ June 30

c. $\square$ Seotember 30 d. $\square$ December 31 19 2. Mine identification number (MESA)

3. Mine permit number(s)

5. Name of mine

16. Name of Indian reservation and tribe

\begin{tabular}{l|l|l|l|l|}
\hline \multicolumn{2}{|c|}{ 7. Location of mine } & 16. Name of Indian reservation and tribe \\
\hline i. State & b. County & 8. Telephone number of production records office \\
\hline 2. Latitude & d. Longitude & g. Section & h. Meridian & 9. Check $\square$ if first report \\
\hline Sownship & f. Range &
\end{tabular}

10. PRODUCTION AND DATA FEE COMPUTATION

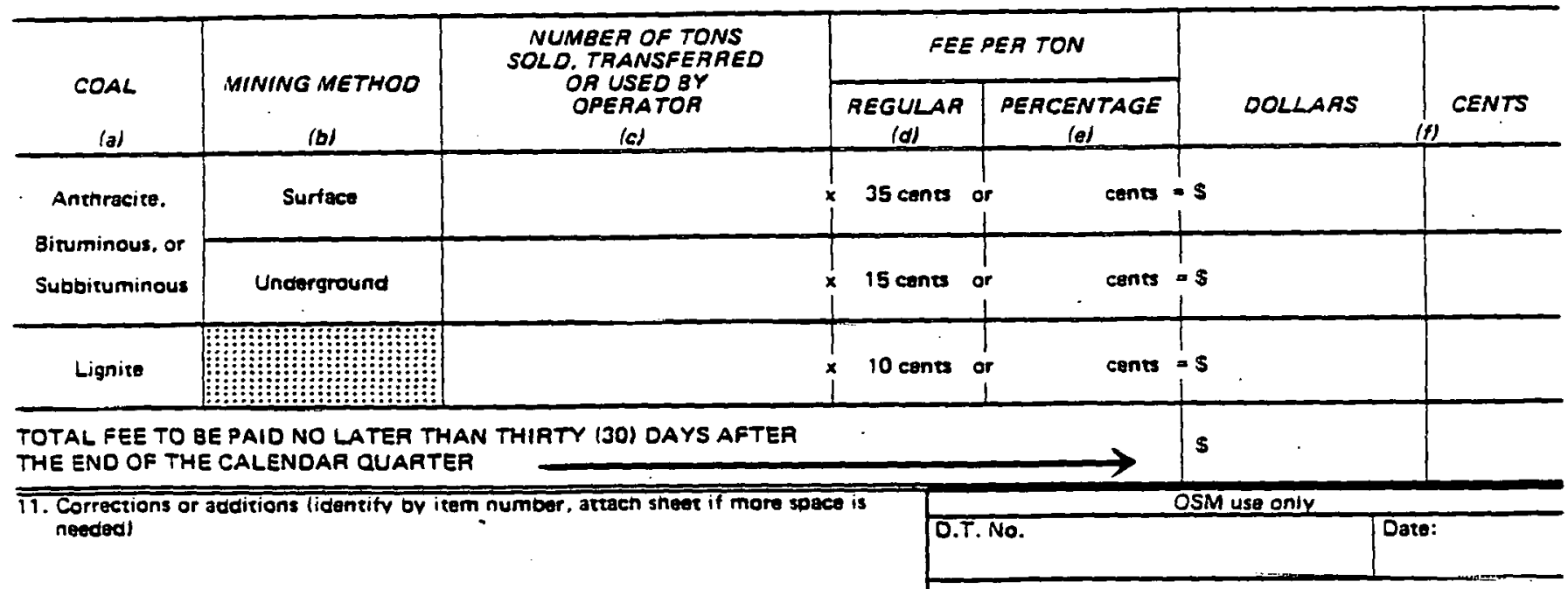

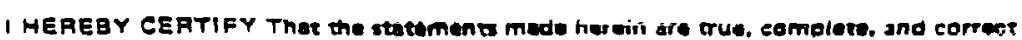
to the bast of my knowledes and betief, and are made in good faith.

Name of reporting person. corporate officer, agent or director on behalf of the oparator, or the operator lorint in ink or type)

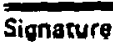

Subseribed and sworn to me this daty of

19 in the presence of

$[$ SEAL $]$

NOTARY PUBLIC

My Commission Exuires: 19

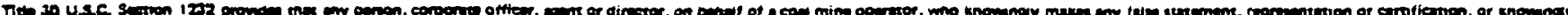

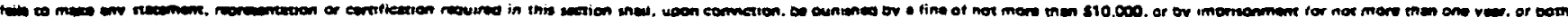




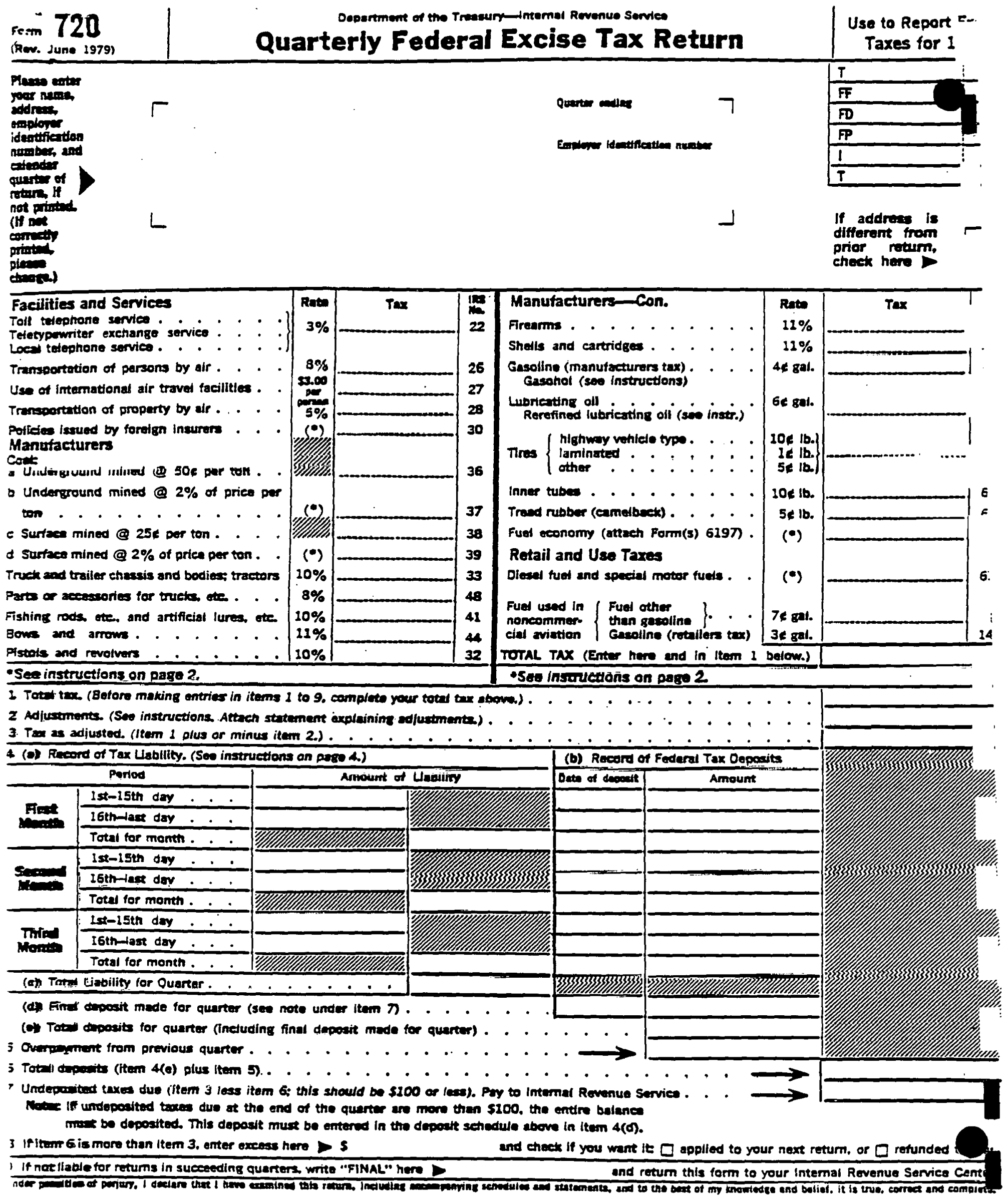


These instructions refer to the item number, or letter under the designated item number on the form.

Item 1 - Identifies the calendar quarter and year of the report.

Item 2 -Identifies the MESA 7-digit identification number.

Item 3 -Identifies the State or Fecieral permit number(s) that are associated with MESA identification number.

Item 4 - Identifies the name and mailing address that you use as an operator.

Item 5 -Identifies the name of the mine that you use for MESA.

Item 6 - Identifies the name of the reservation, and the name of the Indian tribe if the mine is on an Indian reservation.

Item 7 - (a) and (b) identifies the State and the county where the mine is located:

(c) and (d) identifies the latitude and longitude from your mine map: or.

$(e),(f),(g)$ and $(h)$ identifies townshio. range, section, and meridian for your mine if it is located in this manner.

Item 8 - Identifies the telephone number where you keep your production records.

Item $9-$ If this is your first report, check the square.

Item 10 - (a) Anthracite, bituminous, and subbituminous coals are.defined in the Fee Collection and Coal Production Regulations to mean all coals other than lignite coal. Lignite coal is defined in Part 837 to mean consolidated lignitic coal having less than 8.300 British thermal units per pound, moist, and minerai-matter-free. British thermal units per pound are determined by Parr's formula, page 213, equation 3, D-388 (reapproved 1972), Part 26, 1976 Annual Book of ASTM Standards.

(b) Surtace coal mining includes reclaimed coal. Underground coal mining includes in situ mined coal.

(c) Insert the number of tons of coal sold, transferred or used from your mine during the calendar quarter for each mining method (surface or underground)

(d), (e) and (f) The per ton reclamation fees are:

(1) If the gross value of surface mined anthracite, bituminous. or subbituminous coal is $\$ 3.50$ per ton or more, the fee is $\mathbf{3 5}$ cents per ton: if the value is less than $\$ 3.50$ per ton, the fee is 10 percent of the value for each ton of coal.

(2) if the gross value of undergrounid mined anthracite. bituminous. or subbituminous coal is $\$ 1.50$ or more. the fee is 15 cents per ton; if the value is less than $\$ 1.50$ per ton, the fee is 10 percent of the value for each ton of coal.

(3) If the gross value of lignite coal is $\$ 5.00$ per ton or more. the fee is 10 cents per ton; if the value is less than $\$ 5.00$ per ton. the fee is 2 percent of the value for each ton of coal.

If the regular fee is applicable to the coal from your mine. multiply the tons under (c) by the appropriate fee under (d), and place results under (f).

If the percentage fee is applicable to the coal from your mine. multiply the tons under $(c)$ by the ap. propriate percentage value under $(e)$ and place results under $(f)$.

NOTE: If you submit a fee based on a percentage of the value of coal. you shall include with your fee and production report documentation supporting the alleged coal value. Based on this information and any additional documentation, including examination of your books and records. that the Director may require, the Director may accept the valuation submitted by you or may determine the value of the coal.

Item 11 - Self explanatory.

CERTIFICATION

Operators who are required to file reports for more than one mine in a calendar quarter may elect to submit a single notarized certification which clearly identifies and incorporates the attached individual reports. 


\section{Instruations}

Atuditionat information on excise taxes is con. tained in: Fiplication $\mathbf{5 1 0}$ available free from any Internal Rtrenue Service office.

Narmesudrese, and empioyer identfiention moroter you first file form 720, a pro addressedereturn will be malled to you overy thre-morths. Please use the preaddressed form: If ittls lost, request another. Untess al ready.shown on the preaddresed form. enter at ther trate of the space provided for the tax payerserrame. the ending month and year of chepealeodar quarter for which the retum is fleds.lfiyou must use a non-presddressed foum . nipeor print your name, address, and emptoyere ldentification number exacty as shoun omprovious retums. Do not use an em ployer-idantfication number assigned to prioe:omanes

Yoes i mest: fle a rotum for ench quarta whither os not you incurred any llabillty. If you hin notaroto report, enter "None" In item 3.

Anfurtenenti-Generalty, an adjustment man be allowed for all the taxes reported on Formi 20 : to. correct mathematcal errors or too aditust:payments of tax on transactions. charger: ooprocessing that aro entitied to be madectaxifree.

Eitut irnitem 2 the total of any adjustments ctaimedz 14 you claim an adjustrment, attach a statenoat explaining the basis for it and state. that your: have the required supporting evi dences. You must iderify the IRS Numbers beings adiusted, the amount of adjustment ctaimsod:fonesch, and the period In which the taroliability,was previously reported.

Exmpthene-Some transactions aro ex entotifrim tax. As an illustration, certain ex. emptions ane provided for export transaction anditor transactions involving States, polfyer subdivisionss certain nonorofit educational or. zanizetonsand certain aireraft museume

Weodtr-Keep on file at your principl placepot business or some other comvenient location; duplleate copies of your retum and aceurtepreeonds and accounts of all trans. actonss. They must contain suffietent informa. tors torindinate whother the comect amount of tarxhessbeen: computed and oaid. Also, kep reeordsiand information in support of all ad. justumetssciainied and all exemotions. In the casceot most taxes reportable on Form 720. keacyoop records at least four years from the dates:(1) thertax becomes due, (2) the tax is paidd.(3) )earadiustonent is elaimed, or (4) a chaturfoorretund is filed, whichever is later. If reavindd.yoor records must be aveilabie for inspestoanby the Internal Revenue Service.

\section{Funtriess and Interest}

Ahoidf penalties and interest by correcthy filinger. depositing and paying tax when due. Theramenprovides a penalty of from 5 oment tonarpercost of the tax for late filing unleas reasonableceause is shown for the delay. If you iandatefiling a retum or depositing tax. sendkeafoll explanation with the ratum. Panat tiessameprovided for willful failure to collect anckpay taxy keep records, file retums, and for filingataseor frauduient rotums.

Ponatutiess are also orovided for late poy ment of tam xand for not depositing the proper amount ot tax when due. Neither penaity appliessif'yod_can show reasonable cause for failurerto pay or deposit when due.

Tiree not deposited when duk-The pen. aity. foe failure to make deposits when due is 5 percent of the amount of the underpayment. without regard to how long the underpayment continuens.
Taxes not paid when due.-The penalty for fallure to pay taxes when due is $1 / 2$ of 1 per cant of the unpaid amount for each momth or part of a month it remains unpaid-up to 25 percent of the unpaid amount. The penaity applies to any unpaid tax shown on a retum. It also applies to any portion of additional tax shown on a bill if it is not paid within 10 days from the date of the bill.

These penalties are in addition to the interest charge on late payments.

\section{Facilities and Services}

in determining the amounts paid for communications services, do not include the amount of State or local taxes imposed on these services, it the amount is separately stated in the bill to the customer.

Policies issued by foreign insurers.-The rates of tax not shown on the face of the form are:

(1) Casualty Insurance and indemnity bonds. - four cemts on each doilar. or fractlonal part thereof, of the premium paid on the policy of easualty insurance or the indernnity bond.

(2) Lifo insurance, sickneas and accident poliejes, and annuity contracts. - One cent on each dollar, or frectional part thereof, of the premium paid on the polley of lite, sickness of accident insurance, or annuity contract.

(3) Reinsurance. - One cent on each dollar, or fractional part thereof, of the premium paid on the policy of reinsurance covering any of the contract taxable under (1) or (2).

\section{Manufacturers}

The tax un coal per ton may not exceed $2 \%$ of the price at which a ton of coat in each category is sold. See Notice 476 for further information.

The rates of tax on fuel economy are shown on Form 6197. Fuel Economy Tax, which must be attached to Fom 720 to show the tax com putation:

These taxes apply to the sale or use by the manufecturer, oroducer, or importer of the articles listed. These taxes may also apply to one part of an otherwise nontaxable articlo. such as tires on imported vehicles.

Banis for tar and adjustononta-Generally. the tax is computed on the price for which the taxable artele is sold or lensed. if a taxabie article is sold or leased under a conditional saies contract installmemt payment contract. or chattel mortzage arrangement. compute and pay tax on each payment received during the aunter covered by the recum. For ex. ctusion from the sale price of finance charges. and loeal advertising charges, consult your District Director. There are also soecial rules that apply to the lease of any articte.

If charges for transportation, delivery, insurance, installation, and retail dealer praparation costs are ineluded in the manufacturer's sale price, you may adjust the price by dedueding the actual amoumt paid of incurred for such expenses. For the circumstances un. der which adlustmemt may be made and about tha vidence required to support sueh adiustments, consulk your District Diresctor or the applicable regulations. Adjustment of the manufacturer's sale price may aiso be made for discourtes rebates, and other similar allowances granted to the purchaser. But such discounts, ete. may not be anticipated. Adjustmente may only be made if the purchaser has taken adventage of the discount. etc., before the retum is required to be filed.

If the adjustments are made or the quired evidence is obtained after the retum is filed. the amount of tax involved may be considered an overpayment and you may then take a credit for that amount on a later retum. or file a ntund claim.
Tax shall be computed on a price IIshed by the Commissioner of loternal nue if an article is sold by the mant or oroducer at retail. on consignr otherwise than through an arm's.teng action at less than the fair market prics. the article is used by the manufact ducer in a manner subject to tax.

\section{Trucks}

The Energy Tax Act of 1978 repeale excise tax on bus chassis and bodies atter November 9, 1978. Credits or arte available for sales before Noven 1978 on certain dealer floor stocks consumer purchases from April 20, 19\% November 9. 1978. The sale of parts cessories for use on buses is exempt 1 tax if sold atter November 30, 1971 tubes. and tread rubbier also are exerr.p. tax if sold for use by the purchaser on $\mathrm{CE}$ intercity, local, and school buses. your District Director for information use of Form 637. Certificate of Regi: tax-free purchases of parts and aceestires, tubes, or tread nubber.

The resale of an anticte taxable chassis or body of a truck, truck tra truck-trailer is not subiect to additiona facturers tax. If before the resale the ch or body was merely combined with ce named items such as a fitth wheol, crane, or loading and untoading equ for full list of such items, see sectio (d).

Light-duty trucke-The Revenue Ac 1978 provided that parts and acce may be sold free of tax, effective Decel 1978 tu a vurctraser for resale on of nection with the first retail sale of a light. truck (as described in section 4061(a)(2 which is to be resold by the purchas second purchaser for resale with the tail sale of a light-duty truck.

\section{Retail and Use Taxes}

The rates of tax not shown on the the form are as follows:

Diesel tuet and special motor fuels

(a) Four rents a gallon if sold for used as a fuel in a highway vehicte. that the tax is 2 cents a gallon if sold or used in a highway vehicte which (A) . time of sate or use, is not registered an. not required to be registered for highwa. under the laws of any State or forejgn Ca or $(B)$ in the case of a highway vehicte by the United States, is not used 6. . highwoy.

(b) If fuel is sold subject to tax al cents a galion rate, an additional ta cents a galton is imposed on the user fuel is used in a highway vehicte which at the time of use. is registered or is requi to be registered for highway use und aws of any State or foreign country. in the case of a highway venicle owned United States, is used on the highway.

\section{Special Provisions Applicable to Petroleum Products}

Use in buses.-The Energy Tax Act of 15 provided that amounts equal to the taxes motor fuels and lubricating oil may be to the ultimate ourchaser if the prod used after November 30, 1978, in cert tercity, local, and school buses.

Nonbusiness use.-As of Januar the Energy Tax Act of 1978 repeals cents a gallon reduction or repayment ultimate ourchaser of the taxes on st motor fuels and gasoline, and the repayme

(Instructions continued on $p$ 


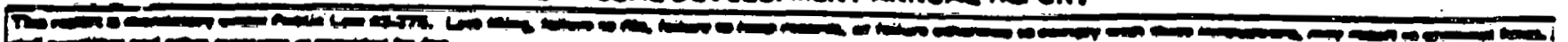
a

\section{Desminicatron onts}

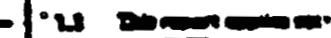

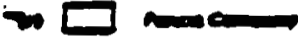
$\rightarrow \square$
and
-

$\rightarrow \square$

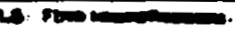

(1)

0

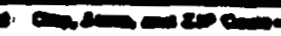

ic $\rightarrow$

$\omega \infty$

12 hamborm

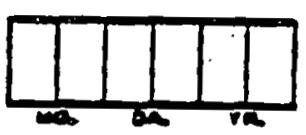

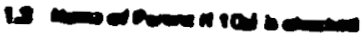

14 Conom

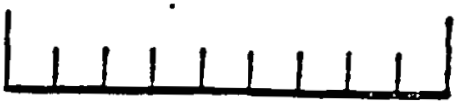

\section{cone onts}

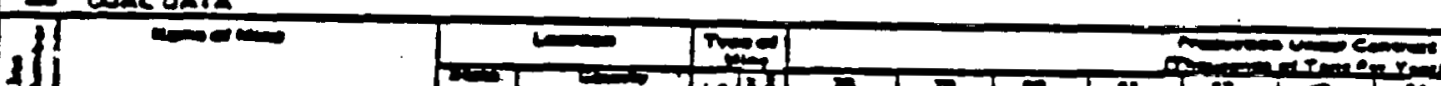

11 .

31

20

1

2.

29

20

20

2.01

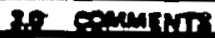

10
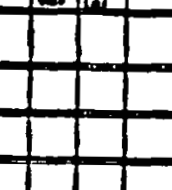

\begin{tabular}{|l|l|l|}
\hline & & \\
\hline & & \\
\hline & & \\
\hline & & \\
\hline & & \\
\hline & & \\
\hline & & \\
\hline
\end{tabular}

$+$

\begin{tabular}{l|l|l|l|}
\hline & & & \\
\hline & & & \\
\hline
\end{tabular}

- 


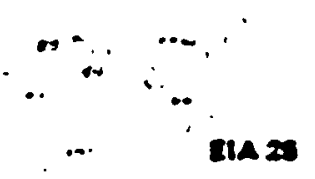

i. PURPOSE

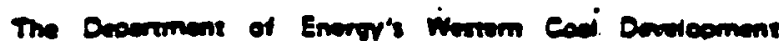
Menitering Amoon will mabl ODE to modter ead production en

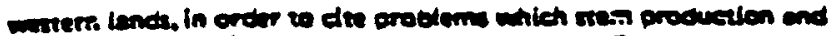

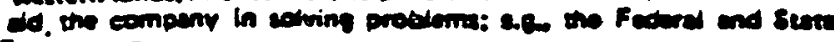

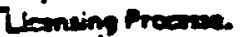

\section{MHO MUST REPORT}

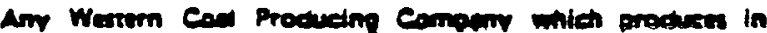

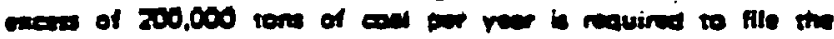

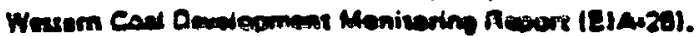

\section{WHEN TO REPORT}

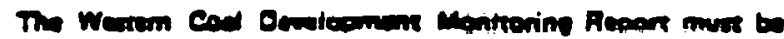

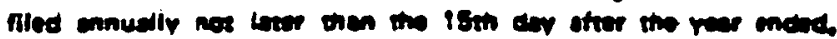

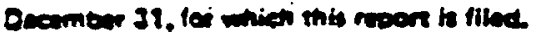

\section{WHERE TO AEPORT}

Firms mat wom tom EtA 30 ros

\author{
US Deveramm of Enower

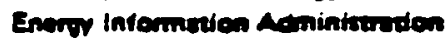 \\ Coes 2808 \\ Whingrea. De zonas
}

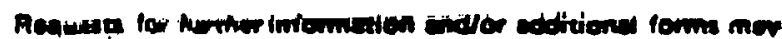

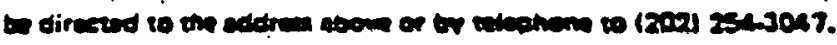

\section{DEFINITIONS}

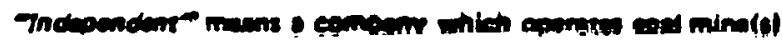

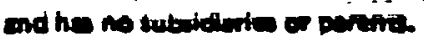

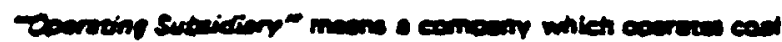

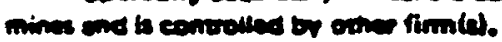

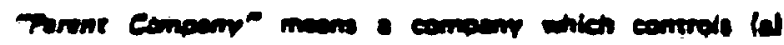

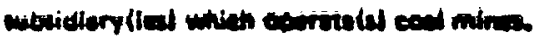

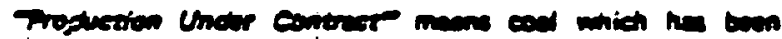

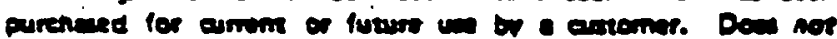

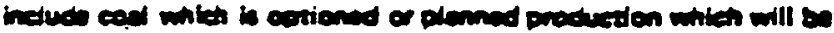

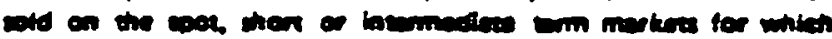

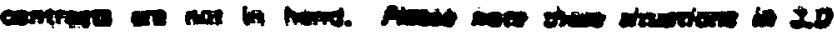
connmes

\section{GEMERAL MUSTRUCTIONS}

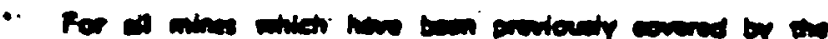

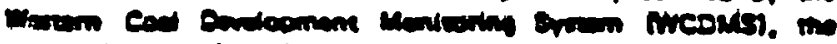

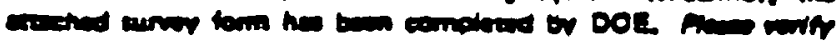

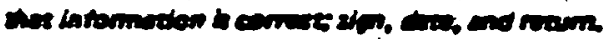

\section{VILSPECIFIC INGTAUCTONS}

\section{8}

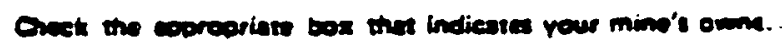
nip lonet.

$\operatorname{tin} 12$

Entwe the due this roin is toling pervench

$\ln 29$

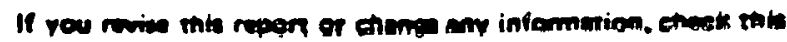
box and fil in the dine.

then 1.0 (d)

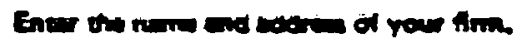

$\ln 8$.

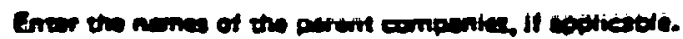

then 14

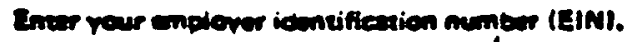

1. 12

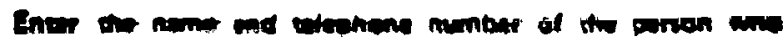

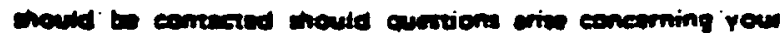
ning .

$\operatorname{lnm} 20$

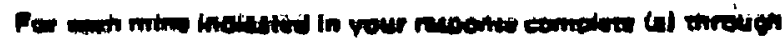

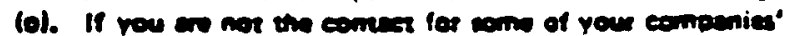

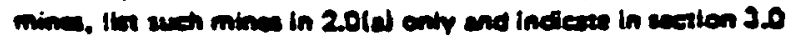

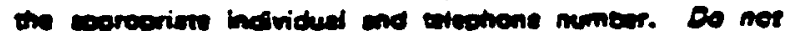

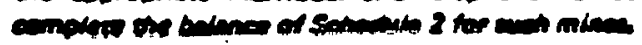

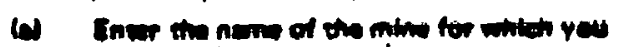
onding

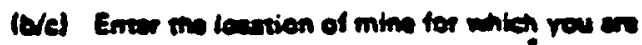
nivinge

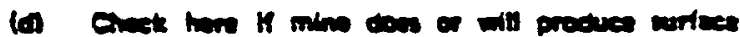
mined ent.

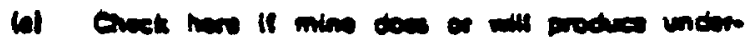
Gores mined enet.

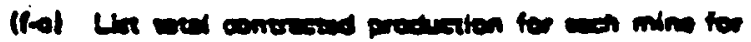

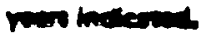

120

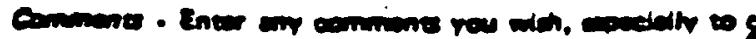

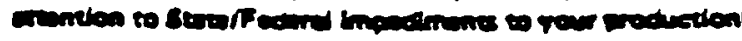




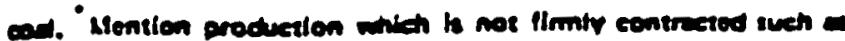

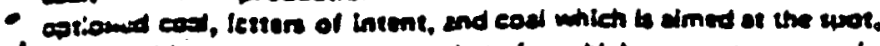

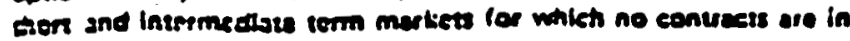
- hovi.jid wileh seme to melintain curremt production.

\section{Item 4.0}

Corthifestion - Entur the name and stite of the Individeal dolip

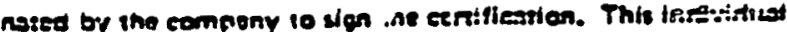
must sign in the snecses prosvided on tha toun and entus the eate of ine signing.

i.

$\checkmark$ 
THIS PAGE

\section{WAS INTENTIONALLY LEFT BLANK}




\section{Appendix C}

\section{Related Publications and Data Sources}

Private sector publications acquire their data from various sources. We have included a partial listing of those publications in this Appendix along with some of the data sources. Although there are additional publications which deal with mining per se, we have limited our review to a representative group of publications dealing strictly with coal information.

- Coal Market - Commentary and Research Service - Source not available

- Coal Industry News - Source not available

- Coal Outlook - Source: Federal Energy Regulatory Commission and the Department of Commerce

- Coal Week - Source: American Association of Railroads

- Kentucky Coal Journal - Source: Department of Energy, Bureau of Mines

- Coal Daily - Source not available

- Coal News - Source: EIA

- International Coal Trade - Source: Bureau of Census; (Car Service Division, Association of American Railroads); Various Forcign Sources 
THIS PAGE

\section{WAS INTENTIONALLY LEFT BLANK}




\section{Appendix D}

\section{Geographic Aggregations Used in Selected EIA Publications}

The terms "area," "region" and "district" appearing on the grid which follows are general categories which need further definition as they apply to the publications which are listed here. For example, the term "region" connotes:

- Producing Region

- Customs Region

- DOE Region

Also, some of the publications use the general category "region" to describe convenient references to groups of states or other geographic entities, and have no apparent relationship to other more structured "regions." Similar references can be made to the categories "district" and "area:"

The following list includes a reference to each of the publications which include data reported in the above manner, as well as an indication of the type of area, region or district.

Area

Coal Distribution (Quarterly) - Coal Producing Area

Underground Storage of Natural Gas by Interstate Pipeline Companies Area of Storage Operations

Highlights of U.S. Import and Export Trade - World Area 
District

Bituminous and Subbituminous Coal and Lignite Distribution (Annual) District of Origin

Crude Petroleum, Petroleum Products and Natural Gas Liquids - P.A.D. District Petroleum Refineries in the U.S. \& U.S. Territories - P.A.D. District Weekly Petroleum Status Report - P.A.D. District Sales of Asphalt - P.A.D. District Supply, Disposition \& Stocks of all 0ils \& Imports into the U.S. - P.A.D. District

Sales of. Liquified Petroleum Gases and Ethane - P.A.D. District

Inventories and Sales of Fuel Oil \& Motor Gasoline: Wholesale Distributors P.A.D. District

Retail Sales and Inventories of Fuel Oil - P.A.D. District Coal Distribution (Quarterly) - Mining District Bituminous Coal \& Lignite Production \& Mine Operations - Mining District Coal - Pennsylvania Anthracite - Customs District Highlights of U.S. Import and Export Trade - Customs District Availability of Heavy Fuel Oils by Sulfur Level - Refinery District

Region

Ri.tuminous Coal \& Lignite Productiul \& Mlle Operaclons - Region Coal - Pennsylvania Anthracite - Producing Region Gas Turbine Electric Plant Construction Cost \& Annual Production Expenses Region

Natural Gas Delivered and Curtailed to End-Use Customers \& Potential Needs for Additional Alternative Fuels - Region Monthly Petroleum Products Price Report - DOE Region Availability of Hcavy Fuel Oils by Sulfur Level - Kegion Highlights of U.S. Import and Export Trade - Customs Region 
Table 9. Geographic Aggregations Used in Selected EIA Publications

COAL

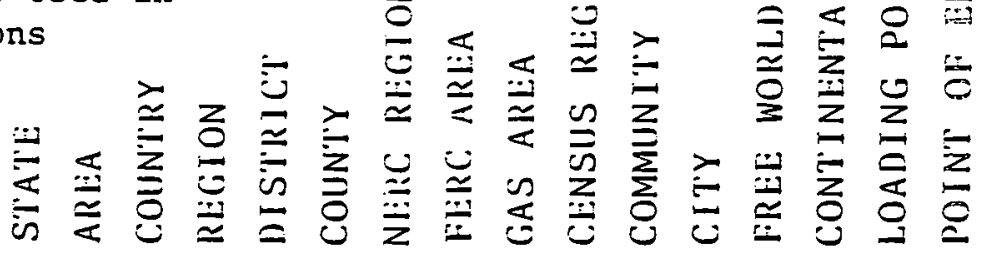

\begin{tabular}{|c|c|c|c|c|c|c|c|c|c|c|c|c|c|}
\hline $\begin{array}{l}\text { Coke and Coal Chemicals } \\
\text { Monthly }\end{array}$ & - & & - & & & & & & & & & & \\
\hline Monthly Energy Review & & & & & & & & & & & & & \\
\hline Redort to Congress (Annual) & & & & & & & & & & & & & \\
\hline $\begin{array}{l}\text { Bituminous and Subbituminous } \\
\text { Coal and Lignite Distribu- } \\
\text { tion (Annual) }\end{array}$ & • & & & & - & & & & - & & & & \\
\hline Report to Congress (Quarterly) & - & & . & & & & & & & & & - & \\
\hline Weekly Coal Production & 은 & & - & & & & & & & & & & \\
\hline Coal Distribution (Quarterly) & 은 & - & & & - & & & & 이 & & & & \\
\hline Coke and Coal Chemicals (Annual) & 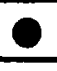 & & 으 & & & e & & & & & & & \\
\hline $\begin{array}{l}\text { Bituminous Coal and Lignite } \\
\text { Production } \& \text { Mine Operations } \\
\end{array}$ & - & & • & & $\bullet$ & $\mathbf{0}$ & & & & & & & \\
\hline Coal - Pennsylvania Anthracite & & & - & - & 0 & - & & & & & & & \\
\hline ECTRICITY & & & & & & & & & & & & & \\
\hline $\begin{array}{l}\text { Steam and Electric Plant Con- } \\
\text { struction Cost and Annual } \\
\text { Production }\end{array}$ & - & & & & & & & & & & & & \\
\hline $\begin{array}{l}\text { Cost \& Quality of Fuels for } \\
\text { Electric Utility Plants } \\
\end{array}$ & - & & & & & . & & & - & & & & \\
\hline $\begin{array}{l}\text { Preliminary Power Production } \\
\text { Fuel Consumption \& Installed } \\
\text { Capacity Data }\end{array}$ & - & & & & & & - & & & & & & \\
\hline $\begin{array}{l}\text { Report on Monthly Electric } \\
\text { Energy \& Peak Load Data } \\
\end{array}$ & 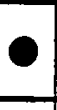 & & & & & & - & & & & & & \\
\hline $\begin{array}{l}\text { EIA Report on } 500 \text { KWH Residential } \\
\text { Electric Bills in Major Cities }\end{array}$ & & & & & & & & & & - & & & \\
\hline $\begin{array}{l}\text { Sales, Revenue \& Income of } \\
\text { Electric Utilities }\end{array}$ & - & & & & & & & & & & & & \\
\hline $\begin{array}{l}\text { EIA Annual Report on Monthly } \\
\text { Comparisons of Peak Demands } \\
\text { \& Energy for Load } \\
\end{array}$ & & & & & & & 0 & & & & & & \\
\hline $\begin{array}{l}\text { Gas Turbine Electric Plant Con- } \\
\text { struction Cost \& Annual Pro- } \\
\text { duction Expenses }\end{array}$ & ○ & & & - & & & & & & & - & & \\
\hline $\begin{array}{l}\text { Statistics of Privately Owned } \\
\text { Electric Utilities in the U.S. }\end{array}$ & & & & & & & & & & & & & \\
\hline Electric Power Monthly & - & & & & & & & & - & & & & \\
\hline
\end{tabular}


NATURAL GAS

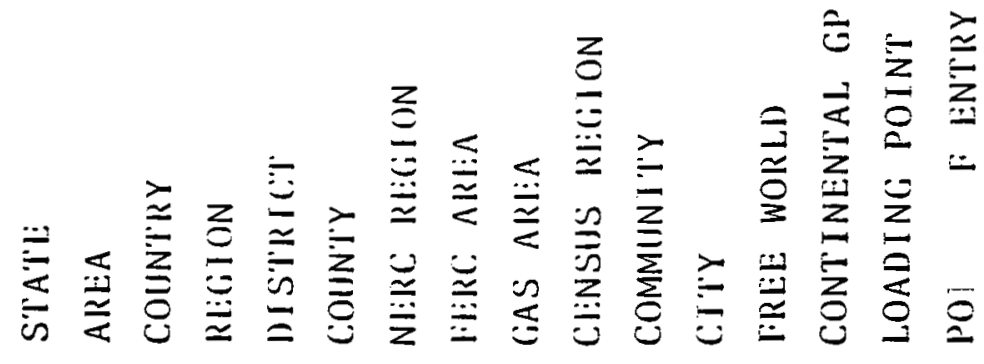
World Natural Gas

Statistics of Interstate Natural

Gas Pipeline Companies

U.S. Imports \& Exports of

Natural Gas

Preliminary Report of Domestic

Vatural Gas Reserves \& Produc-

tion Dedicated to Interstate

Pipeline Companies

Natural Gas Production and

Consumotion

Main Line Natural Gas Sales to

Industrial Users

Natural Synthetic Gas

Underground Storage of Natural

Gas by Interstate Pipeline

Companies

Gas Supply of Interstate Natural

Gas Pipeline Companies

Natural Gas Delivered and Curtailed to End-Use Customers \&

Potential Needs for Additional

Alternative Fuels

SOLAR

Solar Collector Manufacturing Activity.

IMPORTING AND EXPORTING

Highlights of U.S. Import and Export Trade

0

0

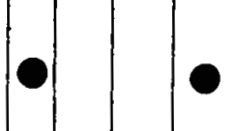

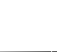

0

-

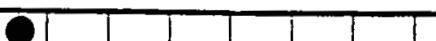

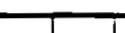

1 1 Tा


Table 9 continued

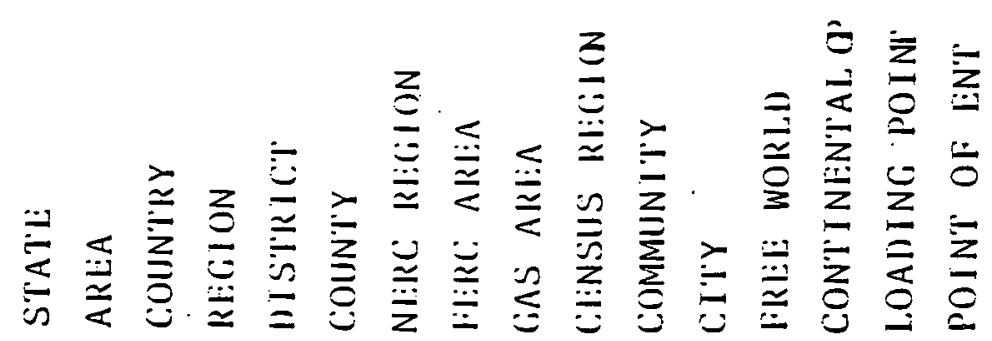

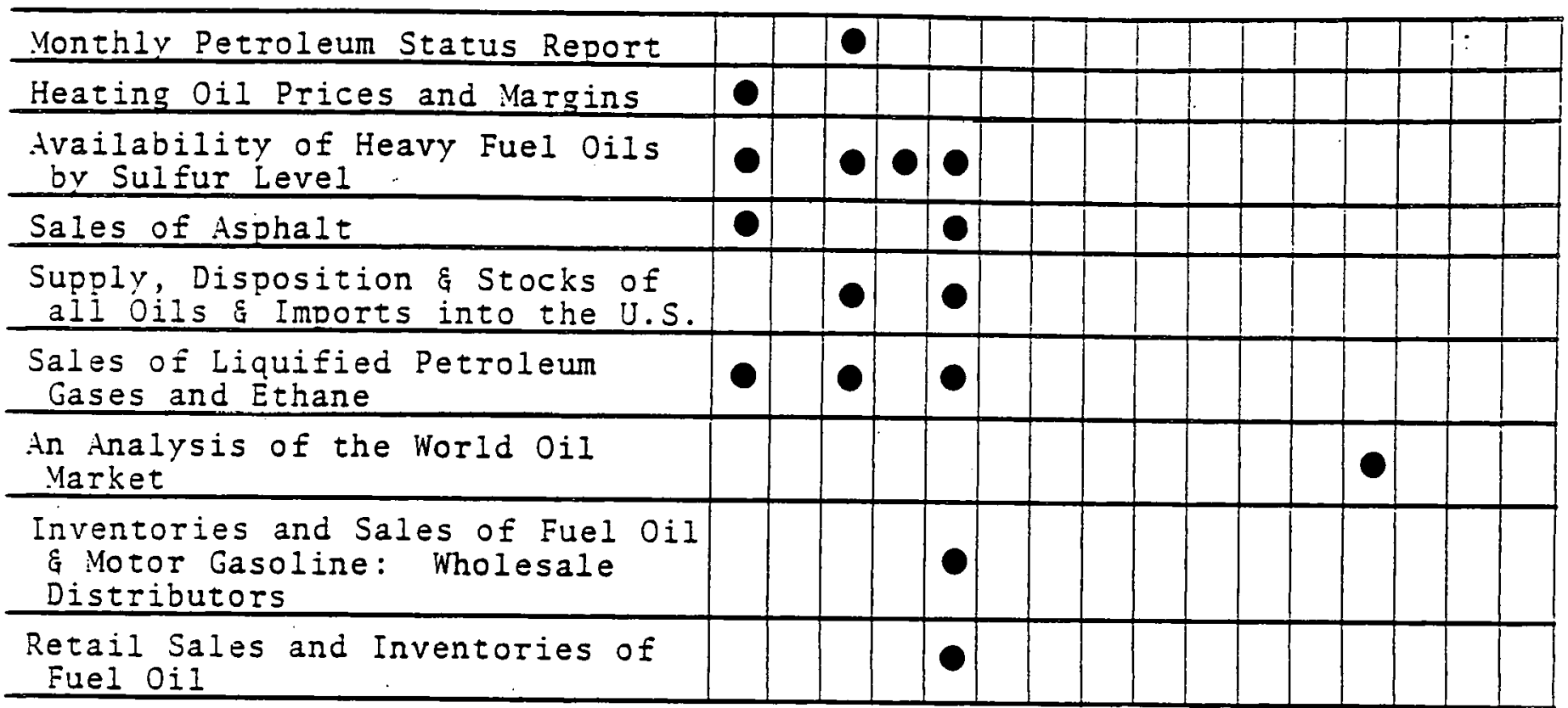

